\author{
UNIVERSIDADE DE SÃO PAULO \\ ESCOLA POLITÉCNICA \\ DEPARTAMENTO DE ENGENHARIA DE PRODUÇÃO \\ PROGRAMA DE PÓS-GRADUAÇÃO EM ENGENHARIA DE PRODUÇÃO
}

EDIVALDO ALBERTO BOLSAM ALVES

A organização do trabalho para o desenvolvimento de recursos imateriais em equipes de saúde da família: um estudo de caso no município de Caraguatatuba.

São Paulo

2015 
A organização do trabalho para o desenvolvimento de recursos imateriais em equipes de saúde da família: um estudo de caso no município de Caraguatatuba

Dissertação apresentada à Escola Politécnica da Universidade de São Paulo para obtenção do título de Mestre em Ciências.

São Paulo

2015 


\section{A organização do trabalho para o desenvolvimento de recursos imateriais em equipes de saúde da família: um estudo de caso no município de Caraguatatuba}

Dissertação apresentada à Escola Politécnica da Universidade de São Paulo para obtenção do título de Mestre em Ciências.

Área de Concentração: Engenharia de Produção

Orientadora: Prof ${ }^{a}$. Livre-Docente Márcia Terra da Silva

São Paulo

2015 
Este exemplar foi revisado e corrigido em relação à versão original, sob responsabilidade única do autor e com a anuência de seu orientador.

São Paulo de de

Assinatura do autor:

Assinatura do orientador:

Catalogação-na-publicação

Alves, Edivaldo Alberto Bolsam

A organização do trabalho para o desenvolvimento de recursos imateriais em equipes de saúde da família: um estudo de caso no município de Caraguatatuba / E. A. B. Alves -- versão corr. -- São Paulo, 2015.

$115 \mathrm{p}$.

Dissertação (Mestrado) - Escola Politécnica da Universidade de São Paulo. Departamento de Engenharia de Produção. 
Dedico este trabalho a minha mãe, Fada. 


\section{AGRADECIMENTOS}

À minha mãe Fada e ao meu pai Edvaldo, obrigado pela compreensão em momentos de minha ausência.

À professora Márcia pela orientação, carinho, incentivo e contribuição ao trabalho.

Aos funcionários e professores do Departamento de Engenharia de Produção da Escola Politécnica da USP.

À professora Sueli, pela valiosa contribuição na construção do trabalho, pelo carinho e atenção.

Ao professor Victorino, pela compreensão, carinho e amizade.

À minha amada companheira Elisângela, por estar sempre comigo.

Aos amigos Leo, Ana Flora, Rafael, Tiago, Pimp's e a todos os outros amigos, pelo apoio, amizade e incentivo.

Ao meu irmão Flávio e sua companheira Viviane, pela amizade e carinho.

À Coordenação de Aperfeiçoamento de Pessoal de Nível Superior (CAPES), pelo apoio à pesquisa.

A todos os profissionais da saúde e gestores das Unidades Básicas de Saúde que participaram da pesquisa. Muito obrigado!

A todos que direta ou indiretamente contribuíram para a realização desse trabalho. 


\section{RESUMO}

Em organizações que operam segundo a lógica de serviço há uma mudança estratégica, com o deslocamento da produção de um produto para um valor. Seguindo esta dinâmica, surgiram na Saúde Pública propostas de modelos de atenção alternativos ao hegemônico, centrado em procedimentos e equipamentos. O presente estudo analisou o modelo da Estratégia de Saúde da Família, cuja proposta centra-se nas necessidades do usuário e no vínculo usuário-equipe multiprofissional, tendo como objetivo investigar como a organização e as condições do trabalho influenciam na utilização de recursos imateriais pelas equipes. Consistiu em um estudo de caso realizado junto a oito equipes de saúde da família do município de Caraguatatuba/SP. A metodologia compreendeu observação direta e realização de grupos focais com os profissionais das equipes. A análise abrangeu a categorização dos temas mais relevantes, em especial aqueles que se relacionavam ao uso e desenvolvimento dos recursos imateriais. Os resultados indicaram que, embora os profissionais valorizassem os aspectos relacionais, o processo de trabalho das equipes encontravase centrado na produção de procedimentos e informações quantitativos dos atendimentos, não incorporadas às práticas do cuidado. Os recursos imateriais, bem como seus resultados, não encontravam uma forma sistematizada de avaliação. $E$, dessa forma, enfrentavam desafios para serem apropriados e desenvolvidos como conhecimento pela organização.

Palavras-chave: Organização do trabalho. Lógica de serviço. Recursos imateriais. Tecnologia em saúde. Serviços de saúde. 


\begin{abstract}
Organizations operating according to the service logic imply a strategic change, the shifting of production from that of a product to that of a value. Following such dynamics, new models of attention emerged in the Public Health System, purporting alternatives to the hegemonic model.This study analyzes the model adopted by the Strategy of Family Health, which is focused on the users' necessities and the bonds between those former and the multi-professional team. Its aim was to investigate how work organization and conditions influence the teams' utilization of non-material resources. To such purpose a case study was carried out in the city of Caraguatatuba, São Paulo state, Brazil.The methodology comprehended direct observation and focal groups with the teams' professionals. The analysis covered the categorization of the subjects considered more relevant, especially those concerning the utilization and development of non-material resources. The results pointed out that although relational aspects were valued by the professionals, the teams' work process was mainly focused on the production of proceedings and information concerning the number of patients assisted, apart from the practices of care.There was no systematic evaluation of the nonmaterial resources and their results, which, therefore, could not be easily appropriated and developed as a knowledge by the organization.
\end{abstract}

Key-words: Work organization. Service logic. Non-material resources. Health technology. Health services. 


\section{LISTA DE ILUSTRAÇÕES}

Figura 1 - Mapa da região de Caraguatatuba .......................................................... 42

Quadro 1 - Composição das equipes das unidades de saúde da Atenção Básica ................. 44

Quadro 2 - Composição da amostra pesquisada..................................................................... 45

Quadro 3 - Composição dos grupos focais ............................................................................. 51

Quadro 4 - Quadro de categorização de recursos ....................................................................... 54

Figura 2 - Abordagem interativa para análise e discussão dos dados .................................... 55

Quadro 5 - Exemplo de criação de códigos, a partir de uma fala ou conjunto de falas

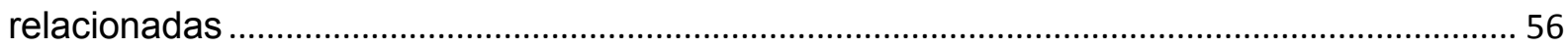

Quadro 6 - Exemplo de criação de categorias, a partir do agrupamento de códigos

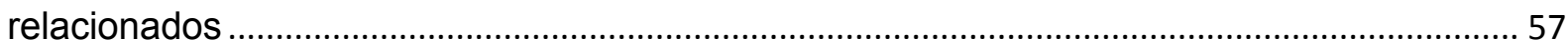

Quadro 7 - Exemplo de definição de categorias mais amplas, a partir do agrupamento de

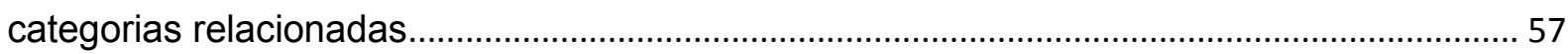

Quadro 8 - Exemplo de definição de temas, a partir do agrupamento de categorias

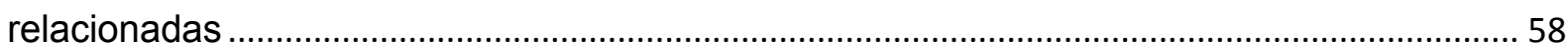

Quadro 9 - Identificação e categorização de recursos .................................................................. 59 


\section{LISTA DE ABREVIATURA E SIGLAS}

AB

ACS

AP

ATS

ENF

ENEGEP

ESF

CEFOR

MED

NASF

QCR

PACS

PESM

PNGTS

PSF

SIAB

SMS

SUS

UBS

UTGCA

UPA

USF

USP
Atenção Básica

Agente Comunitário de Saúde

Atenção Primária

Avaliação das Tecnologias em Saúde

Enfermeira

Encontro Nacional de Engenharia de Produção

Estratégia Saúde da Família

Centro Formador de Pessoal para a Saúde de São Paulo

Médico

Núcleo de Apoio à Saúde da Família

Quadro de Categorização de Recursos

Programa de Agentes Comunitários de Saúde

Parque Estadual da Serra do Mar

Política Nacional de Gestão Tecnologias Saúde

Programa Saúde da Família

Sistema de Informação da Atenção Básica

Secretaria Municipal de Saúde

Sistema Único de Saúde

Unidade Básica de Saúde

Unidade de Tratamento e Processamento de Gás

Unidade de Pronto Atendimento

Unidade de Saúde da Família

Universidade de São Paulo 


\section{SUMÁRIO}

INTRODUÇÃO.

1. SERVIÇO: DEFINIÇÕES E CARACTERÍSTICAS

1.1. Serviço: definições e características

1.2. Um novo olhar para a produção: a lógica de serviço e a concepção do valor do serviço

1.3. Mutações no mundo do trabalho e o conceito de competência.

2. A ESF E A CENTRALIDADE NOS ASPECTOS RELACIONAIS 26

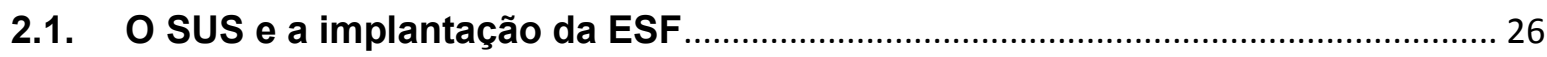

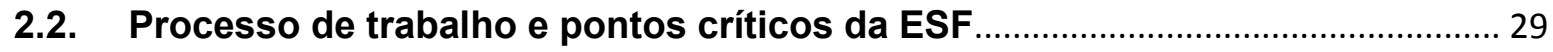

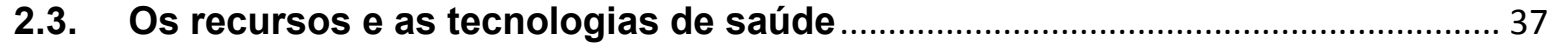

3. METODOLOGIA 42

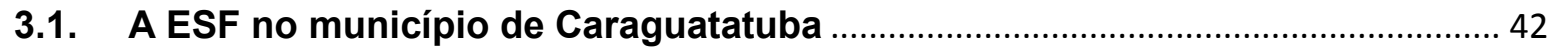

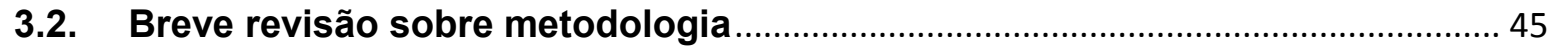

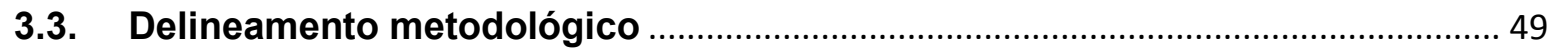

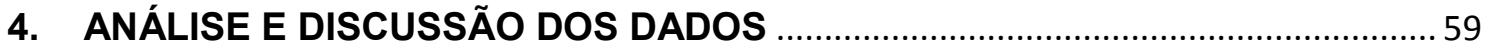

4.1. Tema 1: Concebendo recursos e debatendo a ausência de recursos materiais e não materiais.

4.2. Tema 2: Debatendo a importância das relações e os principais recursos das relações.

4.3. Tema 3: A repercussão de questões organizacionais e de gestão sobre a

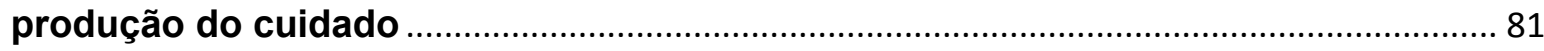

4.4. Tema 4: Concebendo o modelo e o foco de atuação ………................................. 86

4.5. Tema 5: Conhecimentos, habilidades e atitudes importantes para os

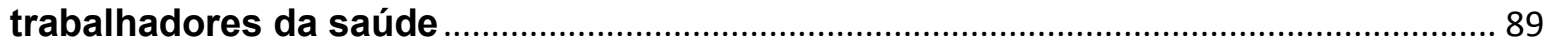

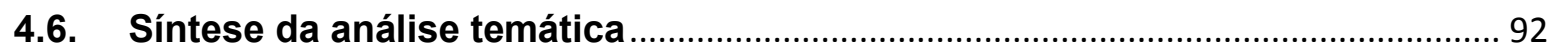

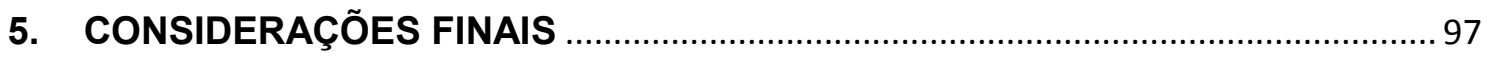

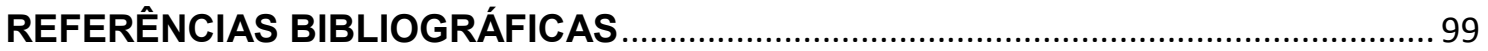

ANEXOS

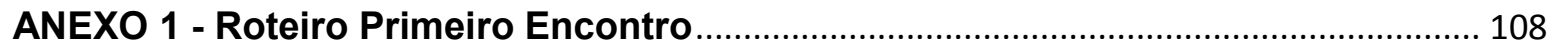

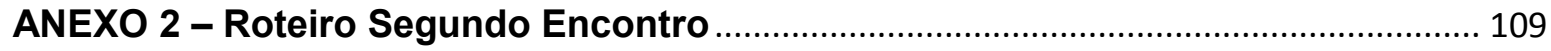

ANEXO 3 - Categorizações Parciais de Recursos - Unidade 1 ..................................... 110 
ANEXO 4 - Categorizações Parciais de Recursos - Unidade 2 ..................................... 111

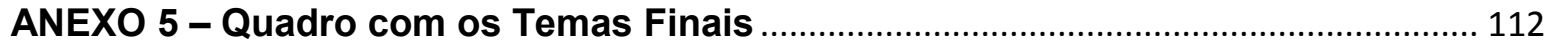

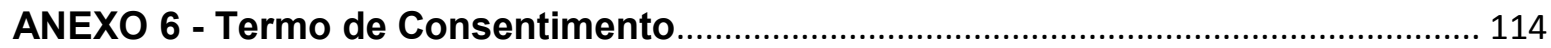




\section{INTRODUÇÃO}

O acentuado crescimento do setor de serviços, observado nas últimas décadas, veio acompanhado de um processo de mudança do paradigma de produção e de organização do trabalho. O "modelo clássico" ou "taylorista" de produção e organização do trabalho, pautado na previsibilidade, na produção de bens padronizados, nos conceitos de tarefa e de cargo e na centralização de decisões, que predominou, quase que hegemonicamente, até as últimas décadas do século XX dá lugar a um novo paradigma de produção e organização do trabalho. Um modelo mais flexível e com contornos menos rígidos, centrado, essencialmente, na produção de um valor ao cliente e pacotes integrados de bens e serviços. Essa integração de sistemas produtivos é denominada na literatura como lógica de serviço.

A literatura da lógica de serviço define que o objetivo central das organizações é a produção do valor do serviço para o cliente, da solução que este busca. Para responder a este desafio há uma contraversão na lógica tradicional de produção: é o valor do serviço a ser produzido que determinará o pacote de bens e serviços que configurará a solução ideal. Nesta nova lógica de produção, alcançam destaque os chamados fatores relacionais ou a relação de serviço entre prestador e consumidor do serviço.

No caso dos processos produtivos de saúde, centro da discussão desta pesquisa, também se notam alterações nos padrões de organização dos serviços, no sentido do ganho de importância dos componentes relacionais. De modo distinto de uma organização manufatureira, o processo de trabalho em saúde, tipicamente uma operação de serviço, sempre se deu diretamente entre produtor e consumidor, ou seja, caracteriza-se por forte presença de componentes relacionais, uma vez que produção e consumo ocorrem, em grande parte, simultaneamente.

Entretanto, em função da influência da lógica taylorista no modelo de organização do trabalho em saúde, os componentes relacionais ou subjetivantes estiveram, tradicionalmente, submetidos aos procedimentos e equipamentos. Seguindo a mesma dinâmica do campo econômico geral, o chamado modelo hegemônico em saúde centrou-se fundamentalmente na assistência médico-centrada e focada no determinante biológico, assumindo a impessoalidade como valor. A fragmentação do cuidado e a falta de resolutividade, dentre outras dificuldades 
observadas, levaram ao surgimento de propostas de organização de um modelo alternativo em saúde.

Em termos conceituais, busca-se um modelo que incorpore uma concepção mais abrangente de saúde, que inclui não apenas o aspecto biológico, mas também outros fatores determinantes e condicionantes da saúde, como os aspectos psicológicos, culturais e sociais. A consideração desses diferentes aspectos corresponde à ideia de integralidade, expoente da mudança paradigmática. Em termos de organização dos serviços e processos de trabalho, a perspectiva da integralidade envolve o deslocamento do eixo central do médico para uma equipe multiprofissional (FRANCO, BUENO e MERHY, 1999).

Optou-se por realizar o estudo junto a equipes da Estratégia de Saúde da Família - município de Caraguatatuba/SP - uma vez que constitui o modelo adotado pelo Ministério da Saúde para reorganização do sistema de saúde. O olhar a respeito do papel do usuário na ESF em acordo com as premissas do modelo da lógica de serviço, pois o resultado do serviço neste modelo depende do uso que o usuário fará das informações que obtém na relação com o prestador do serviço (equipe de saúde), bem como de sua própria atuação como coprodutor do valor do serviço

A crescente valorização dos componentes relacionais no processo de trabalho em saúde implica na necessidade de os serviços pensarem no desenvolvimento destes componentes. Acompanhando essa mudança de perspectiva, tem crescido na literatura da área da saúde os trabalhos dedicados à discussão desses componentes, com destaque para temas como: comunicação, vínculo, acolhimento e relações em equipe.

Com o presente estudo pretende-se responder as seguintes perguntas de investigação:

- Quais as condições organizacionais que possibilitam as equipes desenvolverem recursos imateriais?

- De que forma a organização do processo de trabalho das equipes de saúde da ESF influencia o uso e desenvolvimento dos recursos imateriais 
Para responder à essas perguntas, estabeleceu-se como objetivo geral: investigar como a organização e as condições do trabalho influenciam na utilização de recursos não materiais pelas equipes. E como objetivos específicos:

- Identificar quais são os aspectos da organização do trabalho que interferem no uso dos recursos não materiais;

- Identificar as condições do trabalho que influenciam no uso dos recursos não materiais;

- Identificar as principais dificuldades relacionadas ao uso e desenvolvimento dos recursos imateriais.

Para desenvolvimento deste estudo adotou-se como base os fundamentos teóricos da lógica de serviços e as discussões presentes na literatura sobre tecnologias em saúde, além das diretrizes do Ministério da Saúde. Com base nestes fundamentados foram analisados o corpus e os resultados da pesquisa, além de serem apontadas perspectivas para a organização do trabalho na ESF.

Este trabalho organiza-se em cinco capítulos, divididos da seguinte forma:

No primeiro capítulo encontram-se os fundamentos teóricos da gestão de operações de serviços e da lógica de serviços. São introduzidos os conceitos fundamentais, discutindo-se em especial os conceitos de competência, serviço e relação de serviço.

No segundo capítulo encontra-se um breve histórico sobre o sistema de saúde público brasileiro, a implantação da Estratégia de Saúde da Família (ESF) na reorientação das práticas de assistência e gestão do SUS e a mudança de paradigma embutida no novo modelo assistencial. Nesta parte são apresentados os conceitos fundamentais para a discussão, especificamente de recursos e tecnologias em saúde.

No terceiro capítulo descreve-se a metodologia adotada para coleta, categorização e análise dos dados, lócus, sujeitos e instrumentos de pesquisa a partir da revisão de critérios apontados pela literatura de metodologia científica, justificando a escolha do estudo de caso e da abordagem qualitativa.

O quarto capítulo compreende a análise e discussão dos dados da pesquisa estabelecendo relações entre literatura, objetivos e questões de pesquisa.

O último capítulo traz as conclusões, uma reflexão crítica sobre o estudo realizado e perspectivas para trabalhos futuros. 


\section{SERVIÇO: DEFINIÇÕES E CARACTERÍSTICAS}

\subsection{Serviço: definições e características}

Há décadas o setor de serviços ganha importância na atividade econômica de diversos países, inclusive dentre aqueles que se destacavam pela robustez de seus setores industriais, ou seja, nos países considerados desenvolvidos. O incremento relativo do emprego no setor de serviços, em detrimento do declínio do mesmo no setor industrial, e seu destacado valor na geração do Produto Interno Bruto (GIANESI; CORRÊA, 2012; SALERNO, 2001), foi uma tendência também observada no Brasil, onde o setor abarca mais de $60 \%$ da população economicamente ativa e $68,5 \%$ do PIB (BRASIL, 2012b).

Diante deste cenário de destacado crescimento e relevância econômica, o setor de serviços tem sido foco da atenção de pesquisadores contemporâneos da área de gestão de operações. No entanto, não há consenso com relação à própria definição do termo serviço. Para Salerno (2001), esta dificuldade está relacionada ao fato de tratar-se de um termo que reúne ampla diversidade de organizações, com as mais distintas características, demandas organizacionais e formas de relacionamento com seus clientes ou usuários.

Outro fato observável nas produções bibliográficas relacionadas ao tema é a dificuldade, cada vez mais marcante em distinguir organizações tipicamente manufatureiras (produtoras de bens/produtos tangíveis) e de serviços (produtoras de valores intangíveis), em função de, cada vez mais, as organizações dedicarem-se à produção tanto de bens quanto de serviços (BOWEN; FORD, 2002; FITZSIMMONS; FITZSIMMONS, 2000; ZARIFIAN, 2001a). Salerno (2001) nota que a divisão tradicional da atividade econômica em setores industrial e de serviços tem pouco poder explicativo sobre a dinâmica do trabalho e da produção nas organizações contemporâneas. Gianesi e Corrêa (2012) assinalam que, com frequência, o debate acerca das distinções entre serviços e manufatura incorre na tentativa equivocada e desprovida de sentido, ao menos na perspectiva da gestão de operações, de classificar as organizações em uma das categorias. 
A mudança de paradigma do sistema de produção fordista (pautado na produção em massa de bens cuidadosamente definidos e padronizados) para o sistema focado na produção de um valor ao cliente (conceituado de maneira mais abstrata e com contornos menos definidos) trouxe consigo a necessidade de se repensar as técnicas e métodos da gestão de operações, no sentido da reflexão sobre o que, efetivamente, muda na administração de operações de serviço (SILVA, 2010; BOWEN; FORD, 2002).

Não se trata de uma simples oposição indústria e serviços, mas sim de uma mudança de paradigma. O paradigma fordista, embora originário do setor industrial, influenciou por décadas o setor de serviços. Assim, os serviços de saúde, por exemplo, organizaram suas ações em torno da produção de procedimentos, da repetição de tarefas, primando pela impessoalidade e soluções em massa, não individualizadas. Na medida em que as organizações de serviço cresceram em importância, surge uma lógica de produção de soluções adaptadas ao cliente, o que no setor de saúde se reflete com as iniciativas de reorganização dos modelos de atenção.

Procurando compreender a questão das especificidades na gestão de operações de serviços, as primeiras publicações da área apoiavam-se nas diferenças entre os resultados dos distintos processos de produção como fonte de diferenciação. Silva, (2010) aponta as quatro características a seguir como sendo as mais presentes na literatura como razão de diferenciação dos sistemas de produção (segundo às saídas): intangibilidade dos resultados (imaterialidade), simultaneidade entre produção e consumo, heterogeneidade (dificuldade na padronização tanto de resultados quanto de processos) e perecibilidade (quantificação da possibilidade ou não do resultado do serviço compor estoque). No entanto, segundo ela, atualmente, grande parte dos autores consideram que tais características não são exclusivas de sistemas de produção de bens ou serviços. Elas são relevantes, não como critério de classificação, mas sim como características que impactam a gestão da produção.

Contribuindo com este debate, Teboul (1991) apresenta alguns apontamentos como sendo resultados da influência das características de serviços na gestão das operações. Como efeito da simultaneidade entre produção e consumo, tem-se: 
- Dificuldade na diferenciação do resultado do serviço (produto ou valor) e o próprio processo que o produz;

- Intangibilidade intrínseca do resultado do serviço (imaterialidade);

- Serviços se materializam e são consumidos no ato de sua produção e, dessa forma, não contam com a possibilidade de compor estoque;

- O fator relacional (interações entre prestador do serviço e cliente) ganha importância;

- Ganha importância a experiência em si com o processo de produção do valor do serviço;

As próximas considerações de Teboul (1991) se referem aos efeitos da presença do cliente/usuário no processo de produção:

- Dinamismo conferido ao processo, consequência da ampla variedade e volatilidade das expectativas envolvidas;

- Qualidade percebida é global: fato do cliente vivenciar os processos que compõe o serviço o torna susceptível a generalizações, isto é, detalhes podem comprometer o todo;

- Oportunidades de retroalimentação: produtores do serviço contam com a possibilidade de empregar a experiência do cliente como fonte de informações úteis à promoção de melhorias ao processo.

Resumidamente, a literatura concebe serviços como conjunto de atividades relacionadas a operações de caráter intangível, que: visam a solução para o problema do cliente (GRONROOS, 1995); envolvem pacote de benefícios implícitos e explícitos como experiências perecíveis e imateriais (FITZSIMMONS; FITZSIMMONS; 2000); correspondem à figura mental adotada pelos clientes, funcionários e acionistas que compreende a experiência, o resultado, a operação e o valor do serviço (JOHNSTON; CLARK, 2011); são capazes de interceder na obtenção e disponibilidade de bens físicos e, conjuntamente, na utilização dos intangíveis (NORMANN,1993); e não se relacionam à posse de qualquer objeto, independentemente de estarem vinculados ou não a um bem físico (KOTLER; KELLER, 2006).

Outro grupo de autores define serviço centrado no seu resultado, como mudança da condição ou estado de existência e de atividade do usuário. Deste modo, Gadrey (2001) refere-se ao produto do serviço e o descreve como uma mudança de 
estado na realidade submetida à intervenção. Para Lovelock (1995) serviços são atividades econômicas que constituem valor e concedem benefícios a clientes específicos. Zarifian (2008) trata o termo serviço como sinônimo de trabalho, pois para este autor "trabalhar é gerar um serviço" ou uma modificação no estado ou condições de atividade do destinatário (instituição; usuário no setor público; cliente no setor privado ${ }^{1}$ ). Nesta concepção, o "produto" do serviço é a solução elaborada para um determinado problema. Assim, em última instância, serviço corresponde a produção de um valor.

\subsection{Um novo olhar para a produção: a lógica de serviço e a concepção do valor do serviço}

Para diversos autores a lógica de serviço é um tipo específico de servitização. Este conceito experimentou diversas interpretações ao longo de seu desenvolvimento, tendo sido compreendido, a princípio, como um movimento das organizações para alcançar ganhos estratégicos para os seus produtos, adicionando áreas de serviços ou modificando a caracterização de seu produto como um serviço (SILVA, 2010). A estratégia da servitização caminha no sentido da desconstrução da dicotomia entre manufatura e serviços, tornando-a menos relevante para o olhar da administração, pois aproxima e torna menos nítidas as fronteiras entre a gestão de bens e de serviços (VANDERMERWE; 1988; SILVA, 2010).

A lógica de serviço enfatiza a solução produzida pelas organizações, isto é, o valor, o desempenho ou a utilização do produto (valor de uso) e não a sua propriedade. Trata-se de uma mudança estratégica, de um novo olhar para a produção, de repensar o produzido, indo além do material e na direção das necessidades do usuário (ZARIFIAN, 2001a). Para Silva (2010), a lógica de serviço promove uma inversão no sentido de produção da organização. É a partir do valor de serviço que são determinados os diversos produtos e serviços que conformarão a solução ideal para o cliente.

\footnotetext{
${ }^{1}$ Como a presente pesquisa compreende o estudo de um serviço público, adotou-se a denominação usuário para a pessoa que usa o serviço disponibilizado pelo Estado.
} 
No modelo da lógica de serviço, o uso que o destinatário do serviço fará da solução alcançada e a intensidade da transformação que esta provoca nas suas condições de vida, determinará a qualidade do serviço prestado. Quanto a avaliação dos serviços, não compete um processo avaliativo mecanizado, guiado somente por indicadores numéricos associados à mensuração de valor e produtividade (ZARIFIAN, 2001a, 2001b). Quanto ao valor do uso do serviço, Salerno (2001) e Hubault (2001) se referem, com enfoques relativamente distintos, ao conceito de relação de serviço. Salerno (2001) aborda o conceito de relação de serviço como formas de interconexão entre prestador e consumidor do serviço, com a finalidade de conceder a este a solução para o problema que o levou a buscar o serviço. Assim estabelecido, o conceito de relação de serviço se aplica em qualquer setor que incorpore relações presenciais, não sendo, portanto, exclusividade do setor de serviços. Esse conceito remete à intensidade das relações de cooperação entre os atores envolvidos no processo, apresentando como ponto central a coprodução entre os mesmos. Segundo esta definição, a relação de serviço atua no sentido da desconstrução da dualidade indústria-serviços.

Para Hubault (2001) a singularidade da relação de serviço é realçar o valor do uso do serviço prestado, tratando o valor como composição dos aspectos econômico e subjetivo (capacidade do sujeito envolver-se com o trabalho que realiza). Dessa forma, a relação de serviço, ao mesmo tempo que introduz o reconhecimento da subjetividade no campo econômico, expressa um caráter não unicamente mercantil. Por sua vez, a revelação do valor econômico da subjetividade apresenta aos gestores das operações de serviço dificuldades relacionadas à atividade de gerir as dimensões imateriais da atividade. No caso de serviço de saúde, os profissionais, em geral, são remunerados por aspectos do trabalho que podem ser facilmente quantificados e mercantilizados, não pelos aspectos subjetivantes, como o vínculo que desenvolvem com os usuários, mesmo sendo reconhecida sua importância para a produção do serviço.

Dois desafios são sublinhados por Hubault (2001) na gestão dos recursos intangíveis, sendo eles: a impossibilidade contábil de amortecer investimentos e a particularidade dos recursos imateriais de poderem se desenvolver no uso. Dessa maneira, em se tratando de recursos imateriais, além da tradicional necessidade de assegurar a utilização racional ou econômica dos recursos materiais, devem ser 
criados dispositivos operacionais que auxiliem a compreender o seu controle e desenvolvimento. Com relação ao contexto do serviço público de saúde, Dussault (1992) nota que os resultados dos serviços são difíceis de medir ou avaliar, devido a sua multidimensionalidade.

Em síntese, as especificidades das operações de serviços e, sobretudo, as ações relacionadas ao uso e desenvolvimento dos recursos imateriais, representam novos desafios para os profissionais, que devem desenvolver um novo conjunto de competências e habilidades.

\subsection{Mutações no mundo do trabalho e o conceito de competência}

As profundas e recentes mudanças ocorridas na atividade e na própria concepção de trabalho podem ser indicadas como a origem das discussões em torno do modelo de competência. As características essenciais da concepção de trabalho, que perduravam desde o advento da revolução industrial, estão submetidas a um quadro de profundas transformações, que pode ser sintetizado, segundo Fleury e Fleury (2008), pelos seguintes pontos centrais: relevância da noção de evento, preeminência do conceito de comunicação e consolidação da noção de serviços ponto já discutido neste texto.

- Relevância da noção de evento - evento como o não programado, o imprevisto que é capaz de perturbar o planejamento e a programação dos sistemas de produção. A ação pautada na noção de evento questiona a manutenção da rotina e a capacidade de assegurar a autorregulação. Submete as predefinições de tarefas a segundo plano e, assim sendo, suscita nos envolvidos diretos com a produção do valor do serviço a necessidade de, quase que permanentemente, mobilizar recursos, com intuito de viabilizar soluções para as novas situações;

- Preeminência do conceito de comunicação - a redução no grau de importância das tarefas rotineiras e predefinidas conduz ao reconhecimento da vitalidade da comunicação como ferramenta essencial na promoção da compreensão mútua e, consequentemente, como forma de fomentar a partilha de objetivos e normas organizacionais. 
Esses pontos descritos pelos autores, marcantes nos serviços de saúde e especialmente valorizados no caso estudado, a ESF, implicam em uma dinâmica de trabalho particular. As transformações remetem a uma nova perspectiva de trabalho (ZARIFIAN, 2008) que não se conforma mais como agrupamento de tarefas vinculadas de forma descritiva ao cargo, mas sim como efeito direto da competência mobilizada pelo indivíduo (FLEURY; FLEURY, 2008).

Com relação ao conceito de competência, há na literatura uma grande variedade de definições, que a partir de enfoques distintos aproximam-na de conceitos como aprendizagem organizacional, iniciativa, autonomia e evento. Fleury e Fleury (2000) definem competência como um saber agir responsável e reconhecido, associando-a diretamente com a geração de valor econômico e social à organização e à comunidade. Para efetivar a geração de valor é necessário capacidade de mobilizar, assimilar e transferir conhecimentos, recursos e habilidades. Bitencourt (2001) também assinala que a competência produz efeitos sobre a organização e a sociedade, acrescentando o papel da capacitação neste ínterim. Para a autora, a competência compreende:

(...) um processo contínuo e articulado de formação e desenvolvimento de conhecimentos, habilidades e atitudes de gestores a partir da interação com outras pessoas no ambiente de trabalho, tendo em vista o aprimoramento de sua capacitação, podendo, dessa forma, adicionar valor às atividades da organização e da sociedade. (BITENCOURT, 2001, p. 30)

A noção de competência da autora guarda um aspecto dinâmico, na medida em que pressupõe articulação e interação entre agentes, e encontra-se numa relação de complementaridade com a capacitação profissional. Para Drejer (2000) as competências organizacionais são modeladas por quatro elementos fundamentais (tecnologia, pessoas, estrutura organizacional e cultura organizacional) e, sobretudo, pelas relações entre os mesmos.

Debatendo a relação entre competências e produção de conhecimento no interior das organizações, Bitencourt (2001) refere-se à existência de um ciclo entre o desenvolvimento de ambas, pois é através das competências individuais que as organizações aprendem e, ao mesmo tempo, o desenvolvimento de competências é fundamentado no processo de aprendizagem organizacional. Segundo a autora, se o conhecimento não for incorporado às atitudes e materializado por meio de ações na 
prática do trabalho, não trará benefícios à organização e tampouco estimulará o desenvolvimento das pessoas. Deste modo, o desenvolvimento de competências cumpre importante papel para as organizações, pois promove a tradução do conhecimento em atividades práticas do trabalho, desvinculando-o, consequentemente, do nível da abstração.

Na discussão do modelo de competência proposto por Zarifian (1995, 2001c, 2003, 2008) - uma das principais referências sobre o tema - a competência é concebida como a combinação, dentro de um contexto preciso, de conhecimentos, experiências, comportamentos e um "saber fazer". Para este autor o reconhecimento da competência advém da sua utilização em situações da prática profissional e não se restringe à capacidade técnica de executar tarefas para satisfazer necessidades tecnicamente definidas. Para apoiar esta afirmação, Zarifian (2008) emprega o conceito de evento, isto é, "a solução não prevista com antecedência" (ZARIFIAN, 2008), como a procura pela resposta aos novos problemas apresentados pelo ambiente.

Considerando as discussões, é possível dizer que a competência ganha forma quando a resposta a um determinado evento demanda a mobilização de conhecimentos e habilidades que, por sua vez, exigem motivação. Para Zarifian (1995, 2003, 2008), a competência necessária para que as organizações confrontem os acontecimentos inesperados deve ser socialmente fundamentada e, ao mesmo tempo, inseparável das situações de produção. Nota-se a ênfase dada pelo autor aos aspectos sociais, em contraposição a autores que definem o conceito a partir de um conjunto de conhecimentos profissionais. Ele insiste que “... a competência, definida como um assumir de responsabilidade, é uma atitude social" (ZARIFIAN, 1995).

Essa exigência de assumir responsabilidade predefine uma revalorização e reapropriação do trabalho pelo trabalhador e requer a valorização de sua iniciativa e autonomia (ZARIFIAN, 2003). O autor ressalta, ainda, que a iniciativa do indivíduo não deve ser em relação às prescrições do trabalho, mas sim sobre as lacunas da prescrição, nos espaços de indeterminação da tarefa. São nestes espaços de indeterminação que surgem os eventos; e é exatamente no trato dos eventos que a atuação e envolvimento do trabalhador realmente contribuem para a produção do valor do serviço. 
Dialogando com a abordagem de Zarifian (2008), Hirata (2008), considera como principal virtude de seu modelo de competência o fato do mesmo alçar ao primeiro plano da análise o indivíduo e sua responsabilização, contrapondo-se, dessa forma, às ideias referenciadas no modelo taylorista/fordista de gestão, no qual as decisões são pautadas, basicamente, na noção de posto de trabalho (cargo, função). A partir de perspectiva semelhante, Fleury e Fleury (2001) assinalam que o conceito de competência do modelo gerencial clássico não atende aos desafios postos pelo mundo globalizado, cujas complexas organizações não competem apenas por meio de seus produtos, mas também por meio de competências. Nessa perspectiva, competência não deve ser limitada a um simples estoque de conhecimentos teóricos e empíricos contido no indivíduo, tampouco ser concebida como um conceito encapsulado na tarefa.

Com base em Hirata (2008), apresenta-se a seguir uma síntese dos aspectos relacionados ao modelo de competência de Zarifian $(1995,2003,2008)$ e das precondições para seu desenvolvimento. Os principais aspectos que fundamentam a definição multidimensional do modelo são:

- Tomada de iniciativa e de responsabilidade do indivíduo;

- Inteligência prática para operar as situações - competência para se apoiar em conhecimentos adquiridos e, ao mesmo tempo, os transformar;

- Capacidade de mobilizar redes de atores em torno de eventos; corresponsabilidade e partilha do que está em jogo em cada situação.

Quanto às precondições para o pleno desenvolvimento do modelo, destacamse:

- Estabilidade do emprego e segurança, dentro e fora da organização;

- Possibilidade do trabalhador refletir sobre a sua própria atividade, isto é, estudar e pensar sobre a mesma e, se necessário, reeditá-la pautado em suas reflexões;

- Aprofundamento da formação geral e profissional;

- Pleno reconhecimento, salarial e simbólico, da adoção da lógica competência. É possível notar, por fim, que as contribuições do conceito de competência e da lógica de serviço mostram-se fundamentais para a compreensão dos desafios inerentes às especificidades das operações de serviços e, sobretudo, daquelas com 
forte presença do fator relacional, pois exigem um novo olhar para os objetivos organizacionais e as condições para atingi-los. 


\section{A ESF E A CENTRALIDADE NOS ASPECTOS RELACIONAIS}

\subsection{O SUS e a implantação da ESF}

A atenção à saúde no Brasil foi historicamente marcada pelo enfoque curativo sob o modelo médico-centrado, baseado na clínica individual, na busca espontânea pelo serviço e na cobertura parcial da população. Com a criação do INPS (Instituto Nacional de Previdência e Saúde) em 1966, a assistência à saúde passa a abranger toda a população, contudo o modelo assistencial ainda se manteve baseado na expansão e consolidação da assistência médica curativa e individualizada, em detrimento de medidas de caráter preventivo e de interesse coletivo. Em meados da década de 70, no contexto de esgotamento dos governos militares, tiveram início crescentes mobilizações para reformulação do modelo de saúde, com participação de organizações populares, trabalhadores da saúde e intelectuais, que marcaram o Movimento Sanitário Brasileiro (MINAYO, 1999).

Como resultado do crescente debate, na Constituição Federal de 1988 foi criado o Sistema Único de Saúde (SUS), regulamentado dois anos mais tarde na Lei 8.080. O SUS reconhece a saúde como direito de todos e dever do Estado e adota como princípios e diretrizes: universalidade do acesso, descentralização políticoadministrativa para os municípios, regionalização e hierarquização da rede de serviços de saúde, integralidade na assistência, preservação da autonomia do usuário, participação do usuário, igualdade na assistência. Estes pressupostos são vistos como capazes de produzir impactos positivos, de modo a orientar em direção à superação das práticas de saúde tradicionais.

Na Lei 8080, a integralidade, um dos princípios fundamentais para a mudança paradigmática de saúde, é definida como "conjunto articulado e contínuo das ações e serviços preventivos e curativos, individuais e coletivos, exigidos para cada caso em todos os níveis de complexidade do sistema" (BRASIL, 1990). A assistência à saúde passa a abranger ações de promoção, proteção e recuperação da saúde (SPINK, 2007). Com a ampliação das ações baseadas na perspectiva preventivista e a reorientação da assistência à saúde, foi criado em 1994 o Programa de Saúde da 
Família (PSF), como política nacional proposta aos municípios para organizar a Atenção Básica ou Primária.

A partir de 1997 o PSF passa a ser considerado estratégia estruturante da reorganização do SUS para construção de um novo modelo assistencial em saúde. Ele passa a ser chamado de Estratégia de Saúde da Família, pois evoluiu de um conjunto de ações em saúde para um modelo de atenção centrado na perspectiva coletiva e que visa à integralidade, ou seja, propõe olhar de forma ampliada as necessidades em saúde abrangendo aspectos biopsicossociais, em função de uma mudança na própria concepção do processo de saúde-doença.

Os fundamentos e princípios gerais incorporados para organização da ESF na Atenção Básica refletem uma concepção de atenção em saúde que incorpora as características definidas por Starfield (2002), tais como: integralidade, longitudinalidade, coordenação da atenção, centralização na família, orientação para a comunidade. Segundo Starfield (2002, p. 28), a Atenção Primária é o "nível de um sistema de serviço de saúde que oferece a entrada no sistema para todas as necessidades e problemas" do usuário. Adotando a perspectiva de Starfield (2002), a organização do SUS estabelece que a Atenção Básica ou Primária constitui o primeiro nível do sistema de saúde, a partir do qual o usuário dos serviços acessa os demais níveis, secundário (ambulatorial) e terciário (hospitalar).

De acordo com o Ministério da Saúde (BRASIL, 1997), o PSF nasce com o propósito de superar a crise no modelo assistencial de caráter curativo, marcado por: insuficiência e baixa qualidade dos serviços, desqualificação profissional, excessiva centralização das decisões, fragmentação do cuidado, dificuldade de acesso, insatisfação da população, falta de resolutividade, entre outros. Segundo Franco e Merhy (2006), a prioridade dada aos serviços de natureza hospitalar mostrava-se insuficiente diante das necessidades da população.

A reorganização da assistência à saúde, implicada no modelo proposto pela ESF, elege como alvo de intervenção a família e a comunidade e como instrumento o trabalho em equipes multiprofissionais, com ênfase na produção de vínculo e na corresponsabilidade pela saúde. Em documento sobre a organização do PSF publicado em 1998, o Ministério da Saúde apresenta entre os objetivos do programa: 
A reorganização da prática assistencial em novas bases e critérios, em substituição ao modelo tradicional de assistência, orientado para a cura de doenças e no hospital. A atenção está centrada na família, entendida e percebida a partir do seu ambiente físico e social, o que vem possibilitando às equipes da família uma compreensão ampliada do processo saúde/doença e da necessidade de intervenções que vão além de práticas curativas (BRASIL, 1998, p.1).

Para operacionalização das práticas da ESF e com o objetivo de fortalecer o primeiro nível do sistema de saúde, a Atenção Básica, são criadas as equipes de saúde da família, formadas, no mínimo, por um médico generalista, um enfermeiro, um auxiliar de enfermagem e seis agentes comunitários de saúde (ACS). Cada equipe deve organizar seu trabalho em um território definido, com uma população que não deve ultrapassar 1000 famílias (aproximadamente 4000 pessoas) e ações estruturadas a partir do enquadre de vigilância em saúde. Para isso, dispõe da visita domiciliar como principal ferramenta de busca ativa da população adstrita e coloca em primeiro plano as ações de educação em saúde (BRASIL, 2012a).

Destaca-se a introdução do ACS, apresentado como um integrante fundamental para operacionalização do programa, considerando seu papel no fortalecimento da integração do serviço de saúde com a comunidade (VIEGAS; PENNA, 2013), pois ele é, ao mesmo tempo, parte da equipe e da comunidade, devendo - conforme estabelecido pelo Ministério da Saúde - residir no território de abrangência da unidade de saúde onde trabalha (BRASIL, 2009a). A introdução deste profissional no SUS foi realizada em 1991, por meio da criação do Programa de Agentes Comunitários de Saúde (PACS)2, que pode ser compreendido como um antecessor da ESF, na medida em que serviu de base para sua elaboração.

As equipes de saúde da família, como constitutivas da principal porta de entrada para o sistema de saúde, são responsáveis pelo referenciamento da população aos demais níveis do sistema, articulando-se à rede de serviços pelo estabelecimento de mecanismos de referência e contrarreferência. Esses mecanismos facilitam o estabelecimento de fluxos entre serviços e profissionais dos distintos níveis, na medida que supõem que o profissional/serviço que encaminha um

\footnotetext{
${ }^{2}$ Nos municípios em que existe apenas PACS, o Ministério da Saúde o assume como um programa de transição para a ESF. Neste caso, o ACS encontra-se ligado a uma Unidade Básica de Saúde (UBS), ainda não organizada na lógica da Saúde da Família.
} 
paciente (referência) receberá informações sobre o resultado desse encaminhamento (contrarreferência) (BRASIL, 2002).

\subsection{Processo de trabalho e pontos críticos da ESF}

A organização e a gestão dos processos de trabalho em saúde constituem eixos centrais da reorganização do SUS para construção de um novo modelo assistencial em saúde. Para discutir o processo de trabalho é necessário debatê-lo enquanto conceito aplicado à área de saúde, mas também identificar os desafios enfrentados pelos profissionais e equipes na realidade do trabalho.

Segundo a definição clássica, apresentada por Marx (1996), o processo de trabalho envolve diversos processos separados no tempo e espaço do trabalho, sendo seus componentes: as atividades (trabalho) realizadas pelo trabalhador, a matéria (objeto) sobre a qual se aplica e os meios (instrumentos) através dos quais se realiza o trabalho. Dessa forma, resumidamente, o processo de trabalho compreende as atividades que transformam a matéria prima em produto, devendo, ainda, agregar valor à percepção do cliente. Para Colameo et al. (2007), o processo de trabalho pode ser descrito por meio das possibilidades de divisão do trabalho, dos instrumentos de coordenação e integração, dos objetivos do trabalho, das metas de produção e das tarefas previstas para cumprimento do trabalho.

No caso dos serviços de saúde, o objeto sobre o qual a atividade produtiva se realiza e, portanto, que deve ser transformado, não é um material, mas certos estados ou condições pessoais ou sociais, biológicas ou subjetivas. Quanto aos meios de produção, abrangem os materiais (máquinas, ferramentas e equipamentos), mas também os imateriais, como conhecimentos e habilidades utilizados (FARIA; ARAUJO, 2010). No caso da ESF, os meios ou recursos mobilizados são essencialmente imateriais e o resultado final esperado consiste em atender as necessidades do usuário, o que determina os objetivos das diversas atividades que compõem o processo de trabalho. Estas atividades, sejam executadas por um profissional ou por um grupo de profissionais, devem estar articuladas aos objetivos que a equipe coloca para seu trabalho, de maneira a permitir a criação de um projeto conjunto e a não fragmentação do cuidado. 
O objetivo do processo de trabalho é a produção de um dado objeto ou condição que determina o produto específico de cada processo de trabalho. Com esse produto, por sua vez, pretende-se responder a alguma necessidade ou expectativa humanas, as quais são determinadas ou condicionadas pelo desenvolvimento histórico das sociedades (FARIA; ARAUJO, 2010, p. 22).

Outra característica do processo de trabalho em saúde é sua intangibilidade. Isso quer dizer que o resultado, via de regra, não consiste em um produto destacado, cujas etapas de produção podem ser estritamente determinadas, não podendo ser apropriado pelo usuário como mercadoria. Enquanto que a delimitação tradicional do conceito de processo de trabalho definiu-o em relação à produção de bens materiais, que podem ser apropriados (GONÇALVES, 1992).

Na ESF, distintamente do trabalho centrado em procedimentos e protocolos rígidos, que tem como resultado um produto material, os resultados se dão durante o ato mesmo de cuidar, bem como na posterior adoção pelos usuários das orientações fornecidas pelos profissionais. O trabalho previsto neste modelo envolve relações complexas com o usuário, tanto do ponto de vista técnico - saber operacional - quanto social - relacionamentos com usuário e família - e emocional - no trato com situações de risco ou fragilidade (COLAMEO et al., 2007). Idealmente, as soluções devem estar adaptadas à realidade do usuário e serem com ele pactuadas, de maneira a garantir sua participação ativa no próprio cuidado.

\footnotetext{
Portanto, no processo de trabalho em saúde há um encontro do agente produtor (com suas ferramentas - conhecimentos, equipamentos) e do agente consumidor (com suas intencionalidades, conhecimentos e representações), que torna o agente consumidor parte objeto daquele ato produtivo, mas ainda agente, que interfere no processo (MERHY; FEUERWERKER, 2009).
}

Observa-se que o resultado almejado leva em consideração o valor de uso do serviço pelo usuário, na medida em que atende às suas necessidades e, portanto, deve ser capaz de lidar com a heterogeneidade dos indivíduos (SILVA; LANCMAN; ALONSO, 2009). Contudo, por sua imaterialidade, o processo de trabalho na ESF, incluindo suas etapas, recursos e resultados, são difíceis de serem determinados, controlados e avaliados.

Embora a ESF represente uma proposta de mudança do modelo de assistência, estudos no campo da saúde têm apontado desafios diversos para que ela 
se efetive como uma alternativa mais resolutiva e eficiente de prestação de serviços. Antes discutir esses desafios, mostra-se importante precisar a noção de resolutividade. Na presente pesquisa, adotou-se a seguinte definição:

\begin{abstract}
Considera-se resolutividade a resposta satisfatória que o serviço de saúde fornece ao usuário quando busca atendimento a alguma necessidade de saúde. Essa resposta não compreende exclusivamente a cura de doenças, mas também o alívio ou minimização do sofrimento e a promoção e manutenção da saúde (ROSA; PELEGRINI; LIMA, 2011, p. 350)
\end{abstract}

Para pensar resolutividade é importante destacar o papel de vigilância territorial em saúde exercido pelas equipes. A avaliação da resolutividade na ESF não pode se limitar aos resultados obtidos junto aos usuários que buscam a unidade, deve estender-se também aos problemas identificados através da busca ativa. Os autores Turrini, Lebrão e César (2003) identificaram esse aspecto como um limite importante dos resultados obtidos em seu estudo sobre resolutividade.

Quanto a discussão sobre os desafios da ESF, Merhy e Franco (2001) apontam a existência de uma defasagem entre o discurso de mudança e as práticas assistenciais implementadas, de maneira que é possível dizer que as fragilidades da ESF não conseguiram inverter a lógica de produção dos serviços. Segundo esses autores, a produção do cuidado ainda se mostra reduzida à realização de procedimentos centrados nos profissionais, em detrimento do desenvolvimento de práticas do tipo produção de vínculo, acolhimento e autonomia.

A partir de um estudo realizado junto a USFs, Camuri e Dimenstein (2010) também observaram a manutenção de práticas de cuidado fragmentadas segundo a categoria profissional, além de processos de trabalho organizados de modo burocratizado e hierarquizado. Nota-se que, pelas características dos serviços de saúde, a produção de resultados eficientes não é compatível com a centralização e burocratização, sendo que sua organização e gestão apresentam exigências específicas (DUSSAULT, 1992). Este autor nota ainda uma maior tendência de centralização das decisões no setor público, porque os profissionais estão submetidos a um poder central, o Governo. Entretanto, as equipes de saúde necessitam de autonomia para atender as necessidades específicas de sua população.

No mesmo estudo, Camuri e Dimenstein (2010) consideram fragilidades das equipes quanto ao desenvolvimento de acolhimento e à responsabilização pela 
demanda, bem como "dissociação tradicional entre condições de vida e saúde, que marca de forma indiscutível a formação dos profissionais de saúde e as políticas públicas" (CAMURI; DIMENSTEIN, 2010, p. 812).

Em estudo sobre o processo de trabalho junto a USF, Marqui et al. (2010) observam um grande número de contratos temporários como fator que dificulta o estabelecimento do vínculo do profissional com o serviço e a população atendida. Além disso, também se referem à falta de interação dos trabalhadores e individualização do trabalho, com consequências negativas para o fluxo das informações, e à falta de qualificação profissional entendendo seus efeitos estendidos para além da capacitação técnica, mas também para as relações sociais estabelecidas inter e intra-equipes e com os usuários. Nesse sentido, Almeida e Mishima (2001) apontam a necessidade de capacitação dos membros da equipe, composta por profissionais formados em uma clínica individualizante, que enfrentam dificuldades na adaptação efetiva ao novo modelo de saúde, que exige o trabalho coletivo, sustentado pela articulação das ações e a interação dos profissionais.

Diante das fragilidades observadas na implementação do novo modelo, o Ministério da Saúde tem proposto uma série de ações para a consolidação da ESF, dentre elas tem-se: a partir de 2001, a implantação de Polos de Capacitação e Educação Permanente dos profissionais que atuam nas USFs; o incentivo financeiro aos municípios para ampliação das equipes para a inserção das equipes de saúde bucal na USF (BRASIL, 2006a); a criação em 2008 dos Núcleos de Apoio à Saúde da Família (NASF), compostos por profissionais de diferentes áreas, para atuarem no apoio e em parceria com as equipes de saúde da família ${ }^{3}$.

De modo geral, a literatura aponta a necessidade de um novo arranjo dos processos de trabalho e gestão em saúde na ESF, considerando que o trabalho em saúde é essencialmente relacional e deve atender à necessidade do usuário. Ou seja, o resultado final esperado é, como em qualquer outro sistema de prestacão de

\footnotetext{
${ }^{3}$ Dentre outras ações, o Ministério da Saúde criou: um banco de dados sobre indicadores produzidos pelas unidades que compõem a Atenção Básica (Sistema de Informação da Atenção Básica/SIAB) para avaliação das ações em nível nacional; e um departamento específico no Ministério da Saúde para operacionalização e apoio técnico aos estados e municípios na implementação da ESF (Departamento de Atenção Básica/DAB).
} 
serviços que apresentam convergências com o modelo da lógica de serviço, a solução de problemas do usuário.

Nesse sentido, as ações da ESF são organizadas "com a intenção de conscientizar o usuário para que atue na manutenção da própria saúde. Assim, os papéis do prestador e do usuário são repensados" (SILVA, 2010, p. 19). Segundo esta autora, as mudanças na área nos remetem a este novo conceito de serviço, cujo resultado depende do uso das transformações obtidas pelo usuário na relação com o profissional de saúde. Dessa forma, tem se estabelecido um novo papel do usuário no processo, como corresponsável pelo cuidado e como coprodutor do resultado. Contudo, em estudo sobre a participação dos usuários da USF nos processos de produção de saúde, Crevelim e Peduzzi (2005) assinalam que embora as características peculiares da ESF pareçam favorecer a integração entre comunidade e equipe, na prática os usuários não têm sido incluídos na dinâmica de trabalho e no planejamento das ações.

A lógica proposta é usuário-centrada, pois o usuário representa as necessidades de saúde a serem atendidas, a eficácia do serviço relaciona-se ao uso das transformações obtidas por ele, que, segundo o Ministério da Saúde, tem papel fundamental na gestão do sistema, pois deve também avaliar a eficácia e a eficiência dos serviços. A consideração das necessidades do usuário - sejam elas "necessidades referidas" por ele ou aquelas "necessidades percebidas" pelos profissionais (CECÍLIO, 2001) - denota a importância da produção de um valor do serviço para o mesmo.

Nesse sentido, os resultados do serviço tomam corpo na "transformação das disposições de ação dos destinatários, e que serão avaliados por estes últimos (o beneficiado)" (ZARIFIAN, 2003, p. 98). Entretanto, o fato dos resultados na lógica de serviços dependerem das transformações provocadas pelo processo produtivo no usuário ao longo do tempo, acarreta dificuldades para a avaliação dos resultados. A eficácia esperada não é focal (imediata), mas sim global (permanente) (MERHY, 2007). Nesse contexto, o profissional necessita desenvolver ferramentas de comunicação com o usuário, de maneira a favorecer sua vinculação com o mesmo, pois o vínculo é reconhecido como um dos fatores que pode favorecer a adoção pelo usuário de um papel ativo no processo de cuidado. A responsabilidade em vincular- 
se ao usuário carece de aproximação entre realidades, por isso a inclusão na ESF da visita domiciliar como ferramenta e a definição de um território para cada equipe.

O modelo de atenção à saúde em implantação no sistema de saúde brasileiro envolve uma mudança na concepção tradicional de atuação profissional. Para Zarifian (2001b) os serviços que contam com as características apresentadas exigem o envolvimento subjetivo dos atores envolvidos e de uma comunicação próxima e autêntica. A prática profissional passa a ser concebida como ação que se estende do tratamento da doença para o trabalho com as situações determinantes das necessidades e condição de saúde, as quais incluem os fatores subjetivos, culturais e sociais. Trata-se da integralidade na atenção à saúde, definida como um princípio do SUS.

[as necessidades] não serão nunca "naturais", como tampouco o é o trabalho; não serão características de um ser natural abstrato, como alimentar-se, por exemplo, mas específicas quanto ao conteúdo e à forma: precisa alimentarse de um certo modo, comendo coisas específicas e de uma maneira específica, pois só assim se reproduz como ser humano (GONÇALVES, 1992, p. 24).

Em termos de organização dos serviços e práticas de saúde, a perspectiva da integralidade abrange a assistência curativa, mas centra a atuação sobre o aspecto preventivo, incluindo os aspectos não estritamente biológicos ligados à condição de saúde. O reconhecimento desses determinantes evidencia o conhecimento ligado às demais profissões de saúde, descentrando apenas do profissional médico. Indica, também, a necessidade de colaboração multiprofissional como aspecto importante para se atingir a integralidade. A respeito desta reorganização do processo de trabalho, Franco; Bueno e Merhy (1999) notam que ocorre um deslocamento do eixo central do médico para uma equipe multiprofissional. Assim, no cotidiano dos serviços, os profissionais devem “...criar dispositivos e adotar processos coletivos de trabalho que permitam oferecer, para além das ações demandadas pela própria população a partir de experiências individuais de sofrimento, ações voltadas para a prevenção" (MATTOS, 2004, p. 1413).

Como efeito da mudança de concepção de saúde, observa-se uma alteração expressiva em dois aspectos da prática em saúde. Primeiro, o profissional não se limita mais a atender sozinho, sem debate e troca de informações. O trabalho em equipe exige o compartilhamento de decisões e construção de consensos quanto aos 
objetivos, meios e resultados do trabalho. A interação entre a equipe consiste em um requisito para evitar o atendimento fragmentado e, por conseguinte, a comunicação torna-se uma competência exigida de todos os profissionais envolvidos no cuidado. Nesse contexto, é importante reconhecer, como notou Mascia (2007), que as trocas de informações extrapolam as instâncias formais (reuniões de equipe) e se torna subsídio à integração dos profissionais. Além disso, conforme salienta Zarfian (2001b), a comunicação também será essencial para adentrar a "caixa preta" que constitui a atividade do usuário, no sentido de identificá-la e conhecê-la para, a partir de então, buscar a produção do valor do serviço adequado às suas necessidades. Ou seja, a comunicação mostra-se fundamental para o trabalho da equipe, que se configura na relação entre intervenções técnicas e interação entre os envolvidos no processo, incluindo o usuário do serviço (PEDUZZI, 1998).

Um segundo aspecto é que o profissional não mais, necessariamente, presta atendimento a um indivíduo isolado, mas sim às famílias e comunidade. Estes, usuários do serviço, considerados como parte do processo para alcançar a integralidade no cuidado, necessitam ser incorporados em um processo de educação em saúde, de maneira que, a partir dos resultados deste processo, possam atingir certo grau de autonomia no cuidado. Segundo Campos (2007, p. 852): "O grau de autonomia se mede pela capacidade de autocuidado, de compreensão sobre o processo saúde/enfermidade, pela capacidade de usar o poder e de estabelecer compromisso e contrato com outros".

Há situaçães em que não cabe a perspectiva de cura, ou de resolução clínica,
mas sim a construção de um usuário que administre melhor o seu próprio
sofrimento. Produzir este tipo de saúde, não se esgota na clínica, na
epidemiologia e nem na vigilância à saúde, outros campos de conhecimentos
competentes precisam ser mobilizados, que agem nos processos relacionais
com o usuário, e que estão implicados com a produção de ações
acolhedoras, de escutas qualificadas e mesmo com as responsabilizaçôes e
compromissos que estes processos comportam, que operam os vínculos
sociais, por exemplo (MERHY; FRANCO, 2001).

Como dito, no exercício de sua autonomia, os destinatários do serviço são considerados coautores da produção do valor do serviço e, sobretudo, do processo de construção da integralidade no cuidado. Deste modo, torna-se essencial que acessem práticas preventivas de saúde capazes de alargar sua autonomia. Campos (2007) destaca duas mudanças como correspondentes a um rompimento com 
aspectos enraizados pelo modelo de atenção tradicional: uma relativa ao objeto e outra à finalidade do trabalho. A primeira compreende a uma extensão do tratamento da doença para os problemas de saúde (situações que aumentam o risco ou vulnerabilidade das pessoas) - correspondente à ideia apresentada pelo princípio de integralidade. Enquanto que a finalidade do trabalho, além de buscar a produção de saúde, deve contribuir para ampliação do grau de autonomia do usuário.

Os pressupostos da ESF acerca da corresponsabilização e de desenvolvimento de autonomia do usuário mantêm correspondência com dois importantes conceitos apontados pela literatura de gestão de operações como sendo características de serviço: a participação do cliente na produção do serviço e o valor de uso para o cliente. Ao participar ativamente do processo de produção do serviço, ou seja, inserirse como coautor na elaboração da solução pretendida, o usuário, consequentemente, assume parte da responsabilidade sobre os efeitos alcançados.

Quanto aos resultados alcançados pela ESF, não estão dissociados das condições de vida do usuário, como acesso aos diversos serviços públicos, situação de pobreza, exposição a problemas sociais, como tráfico de drogas e desemprego. Neste sentido, Almeida Filho (2011) considera que a problematização de saúde deve considerar:

(...) os gradientes socialmente perversos reproduzidos em nossas sociedades refletem interações entre diferenças biológicas, distinções sociais, iniquidades no plano jurídico-político e inequidades na esfera éticomoral, tendo sempre como expressão concreta, empiricamente constatáveis, desigualdades em saúde (ALMEIDA FILHO, 2011, p. 90).

A integralidade surge como um expoente da mudança paradigmática envolvida na mudança de modelo de atenção, que passa a orientar as políticas e práticas de saúde. Para sua efetivação, além da reorientação do cuidado no sentido de práticas de orientação e prevenção, mostra-se necessária a "renovação dos vínculos de compromisso e de corresponsabilidade entre os serviços e a população assistida". (ALVES, 2005, p. 48). 


\subsection{Os recursos e as tecnologias de saúde}

A efetivação das práticas de orientação e prevenção no processo de trabalho da ESF exige que uma determinada relação de recursos seja mobilizada. Por se tratar de uma etapa inserida no processo de produção de um serviço com forte presença do componente relacional (TEBOUL, 1991; GADREY, 2001; SALERNO, 2001; HUBAULT, 2001), ganham relevância os recursos imateriais, essencialmente implicados nas relações diretas entre prestadores e destinatários do serviço. Estes recursos são imprescindíveis para real compreensão das necessidades de saúde pelo usuário, o que determina a qualidade do serviço.

Conforme anteriormente abordado, para Zarifian (2001b) o debate a respeito da qualidade do serviço perpassa dois julgamentos. Primeiro, o julgamento das consequências produzidas pelo valor do serviço e, segundo, o julgamento da eficiência dos recursos mobilizados para a produção do valor que se deseja alcançar - sendo este o ponto de interesse para esta pesquisa. Para o autor, na avaliação do serviço segundo o critério da eficiência da mobilização dos recursos utilizados, há uma subversão da lógica da "gestão clássica" para a "lógica de serviço", tendo como ponto de partida o conceito de pertinência.

Na "gestão clássica", a pertinência do serviço é resultado da relação entre recursos utilizados e objetivos propostos, sendo ambas as decisões incumbência das organizações. É no domínio interno, restrito, que são definidos os objetivos e, a partir destes, são mobilizados os recursos. Enquanto que a eficiência também permanece restrita ao âmbito organizacional, pois é definida como o resultado da relação entre os recursos mobilizados para a produção do serviço e os resultados alcançados (ZARIFIAN, 2001b). Na "lógica de serviço", a pertinência associa-se se ao fator relacional, pois decorre da relação entre as expectativas do usuário (o que este espera obter como resultado/valor do serviço) e os objetivos da organização (mediados pela expectativa do usuário). Nesta perspectiva, será eficiente o serviço que mobilizar os recursos adequados para entregar ao usuário o valor que ele necessita. Assim, a pertinência do serviço prestado dá sentido ao conceito de eficiência e cria, consequentemente, uma nova perspectiva técnica, entrelaçada às competências

humanas e ao objetivo de modificar as condições de atividade dos usuários (ZARIFIAN, 2001b). 
Quanto à definição de recursos, consiste em "qualquer coisa" que represente força ou fraqueza para uma firma ou organização. Os recursos compreendem materiais, capacidades, processos organizacionais, informação, conhecimento e outros, associados "semi-permanentemente" à organização (WERNELFELT, 1984) e que possam capacitá-la para a busca de maior eficiência e efetividade, por meio da idealização e implementação de novas estratégias (WERNELFELT, 1984; BARNEY, 1991). Eles são divididos em: tangíveis - aqueles que podem ser constatados e avaliados com facilidade, de forma direta, como máquinas, equipamentos, recursos humanos e financeiros; e intangíveis - observáveis somente de forma indireta, como a cultura das organizações, relacionamentos, confiança, cooperação e reputação (PENROSE, 1959; RUMELT, 1984; WERNERFELT, 1984; GRANT, 1991).

Com relação às categorizações dos recursos, há uma ampla diversidade de tipologias. Destaca-se abaixo aquelas utilizadas neste estudo, por serem mais amplas e aplicáveis ao objeto estudado.

a) Categoria de Mills, Platts e Bourne (2003): recursos tangíveis - mais ou menos tudo que possui uma forma física; recursos de conhecimento, habilidades e experiência -recursos tácitos que os proprietários, muitas vezes, não sabem que possuem; sistema e recursos processuais - envolve ampla variedade de tangíveis (documentos, sistemas de recrutamento e seleção, medida de performance, processamento de pedidos, sistemas de computadores) que requerem a intervenção de recursos intangíveis como conhecimento, experiência, operadores, usuários; recursos e valores culturais - tipo de recurso intangível desenvolvido ao longo do tempo, dependente, com frequência, da atitude dos fundadores e de eventos passados (memória de situações passadas, valores, crenças, comportamentos preferiveis); e recursos network - grupos de interesses que envolvem a companhia (fornecedores, clientes, autoridades legislativas, assessores) e inclui reputação e a marca;

b) Categoria de Valentin (2001): financeiro - capital e acesso aos mercados financeiros físicos (instalações, equipamentos, configurações e matérias primas); legal - patentes, marcas, contratos que protegem o capital intelectual; intelectual expertise, fórmulas e descobertas; humano - habilidades e expertise individual dos funcionários; organizacional - cultura, costumes, visões compartilhadas, valores, rotinas e relações de trabalho; informacional - clientes e informações sobre 
concorrência; relacional - alianças estratégicas, relações com clientes, vendedores e demais interessados; e reputacional - nomes de marcas que podem reduzir risco percebido ou tem valor simbólico.

A classificação geral de recursos entre tangíveis/materiais e intangíveis/imateriais ${ }^{4}$ encontra paralelo na literatura da área de saúde, na terminologia adotada por Merhy (2007) de tecnologias de saúde, classificadas em duras, leve-duras e leves. A tecnologia dura envolve a utilização de instrumentos e aparelhos, correspondentes aos recursos materiais. Enquanto que os recursos imateriais correspondem à tecnologia leve-dura (saberes estruturados das profissões) e à tecnologia leve, que englobam os componentes relacionais envolvidos na atividade produtiva, tais como escuta e confiança.

Como forma de equilibrar a relação entre resultados e custos decorrentes da utilização de tecnologias, o Governo Federal $^{5}$ adota uma concepção de tecnologias em saúde que engloba equipamentos, materiais, conhecimentos e procedimentos técnicos, correspondentes às tecnologias duras e leve-duras de Merhy, cuja terminologia amplia a concepção de tecnologias, na medida em que acrescenta as tecnologias leves. Isso porque boa parte dos serviços de saúde é realizada por meio da interação entre prestador e usuário, não necessariamente intermediada por equipamentos ou materiais. Em oposição a este tipo de recursos, os recursos imateriais, relacionados à tecnologia leve, desenvolvem-se com o uso e, portanto, devem envolver um tratamento específico, exigindo a reconsideração das práticas e engajamento dos trabalhadores e gestores (Hubault, 2001).

A gestão dos recursos adotada pelo Ministério da Saúde ocorre no sentido de estabelecer uma estrutura de avaliação para apoiar as atividades de incorporação de novas tecnologias pelo SUS (Brasil, 2009b). Com esta finalidade, o governo adota a Avaliação das Tecnologias em Saúde (ATS) ${ }^{6}$, que compreende um conjunto de ações ligadas ao aprimoramento de sua incorporação e à racionalização de sua utilização,

\footnotetext{
${ }^{4}$ Adota-se, a partir deste ponto, exclusivamente a terminologia recursos materiais e recursos imateriais.

${ }^{5}$ Organizada na Política Nacional de Gestão de Tecnologias em Saúde (PNGTS) - Portaria ${ }^{\circ} 2.690$, de 5 de novembro de 2009 (BRASIL, 2010a)

${ }^{6}$ Diversos países possuem programas oficiais de avaliação das tecnologias de saúde, com destaque os desenvolvidos como Alemanha, Canada, França, Holanda, Reino Unido, entre outros. Enquanto que apenas alguns em desenvolvimento (Argentina, Chile, Cuba), justamente com mais dificuldades quanto à restrição de recursos, possuem este tipo de programa (Brasil, 2009).
} 
de maneira a prover informações que auxiliem na formulação de políticas da saúde. Para Nita et al. (2010) a contribuição teórico-metodológica brasileira em termos ATS - principalmente através dos trabalhos de Merhy e colaboradores - inclui a ampliação do conceito de tecnologia em saúde. Entretanto, as ações de gestão do governo federal limitam-se às tecnologias duras e leve-duras, deixando de lado as tecnologias leves, essenciais para a consecução do modelo tecnoassistencial proposto.

Segundo Merhy e Franco (2003), a mudança proposta no modelo assistencial da ESF pressupõe impactar o núcleo do cuidado através de uma transição tecnológica para as tecnologias leves. Estes autores consideram que em muitos casos muda-se a forma de produzir sem, no entanto, alterar o processo de trabalho centrado nas tecnológicas duras. As tecnologias definem o modo como o cuidado é produzido, definindo os custos e resolutividade dos serviços.

Tecnologias, aqui, entendidas como o conjunto de conhecimentos e agires
aplicados à produção de algo. Este conhecimento pode estar materializado
em máquinas e instrumentos, ou em recursos teóricos e técnicas
estruturadas, como tecnologias duras e leveduras, respectivamente, lugares
próprios do "trabalho morto". Por outro lado, este conhecimento pode estar
disperso nas experiências e modos singulares de cada profissional de saúde
operar seu trabalho vivo em ato, como na produção de relações, tão
fundamentais para o trabalho em saúde (FRANCO; MERHY, 2006, p. 116-
117).

A produção da assistência em saúde dá-se no encontro mesmo entre usuário do serviço e profissional, que deve articular os diferentes tipos de tecnologia conhecimentos, instrumentos, normas - para responder às necessidades do usuário, sejam aquelas referidas por ele ou aquelas que o profissional percebe (CECÍLIO, 2001). O processo de trabalho da ESF deve enfatizar escuta ampliada, construção de vínculos e desenvolvimento de confiança, pois estes permitirão ao profissional conjugar conhecimentos e instrumentos com os modos singulares de vida dos usuários. No processo de reconstrução das práticas de saúde, objetivando conceber a produção do cuidado como valor do serviço, há a necessidade de incorporar outros instrumentos na produção dos serviços de saúde. Nessa perspectiva, as tecnologias leves necessitam se constituir em instrumentos do cotidiano do processo de produção do cuidado (FERRI et al., 2007).

Além do tocante à dimensão singular, do contato cotidiano profissional-usuário, a mudança da lógica predominante na saúde deve fazer face às relações 
hierarquizadas que historicamente marcam os espaços da micropolítica de saúde. Segundo Ribeiro; Pires e Blank (2004), a reorganização das práticas em torno das necessidades biopsicossoais envolve uma tensão entre a complementaridade das ações, interdependência dos trabalhadores e a necessidade de ampliação da autonomia técnica de cada profissional. Segundo as autoras, a eficácia e eficiência dos serviços dependem da autonomia técnica aliada à articulação de ações. Para Ferri et al. (2007), a reorganização da saúde será potencializada pela incorporação das tecnologias leves no encontro entre trabalhadores e entre estes e os usuários. 


\section{METODOLOGIA}

Neste capítulo, será discutido o caminho para definição da metodologia utilizada, a partir da revisão de critérios apontados pela literatura de metodologia científica, considerando-se o problema de pesquisa, as questões levantadas e os objetivos de pesquisa. Debate-se a escolha da abordagem qualitativa e de caráter exploratório, bem como a escolha do estudo de caso, como mais pertinente para oferecer respostas para o problema de pesquisa. Em seguida, são apresentados o delineamento metodológico adotado - especificando a escolha das unidades de saúde, dos sujeitos e dos instrumentos de pesquisa - e a metodologia de tratamento dos dados.

\subsection{A ESF no município de Caraguatatuba}

O campo de estudo localiza-se no município de Caraguatatuba (SP), litoral norte do Estado de São Paulo, região formada pelos municípios de Caraguatatuba, Ilhabela, São Sebastião e Ubatuba. Encontra-se a 180 km da cidade de São Paulo e tinha população estimada de 111.524 habitantes em 2014 (Fonte: IBGE).

Figura 1 - Mapa da região de Caraguatatuba

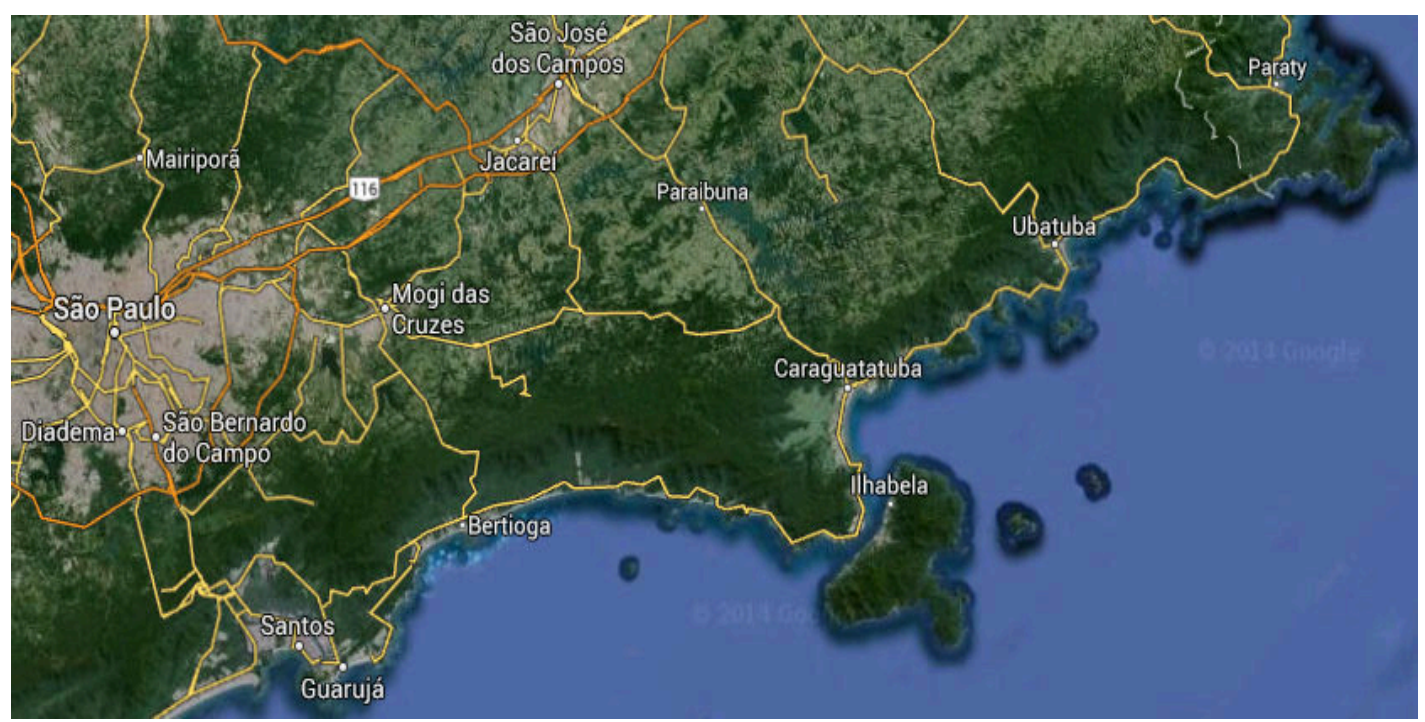

Fonte: Google, 2014

De acordo com Gigliotti e Santos (2013), dos 485,95 $\mathrm{Km}^{2}$ de área territorial, que compreende o perímetro urbano e rural e o Parque Estadual da Serra do Mar (PESM) 
(ocupa $82 \%$ da área total), apenas $36.786 \mathrm{Km}^{2}$ correspondem a área urbana, efetivamente ocupada pelo município.

O processo de urbanização de Caraguatatuba intensificou-se a partir da década de 1970, mediante investimentos em atividades turísticas e grandes empreendimentos imobiliários (SEIXAS, et al, 2010), culminando em elevado crescimento populacional entre 1990 e 2010 (IBGE, 2010b).

No atual contexto econômico, social e político, o município destaca-se no setor turístico, imobiliário e petrolífero, com forte investimento por parte do governo estadual em infraestrutura para o desenvolvimento de instalações de processamento e distribuição de petróleo (INSTITUTO POLIS, 2012). No setor industrial, o destaque do município é a presença da Unidade de Tratamento e Processamento de Gás (UTGCA), que potencializa outros investimentos comerciais para a economia da região. (PREFEITURA DE CARAGUATATUBA, 2013). Como consequência de suas características econômicas, o município atraiu, ao longo de sua história, um grande contingente de mão de obra e, consequentemente, passou por marcantes transformações socioambientais. As áreas mais atingidas por estas transformações são aquelas ocupadas irregularmente, sem infraestrutura e planejamento urbano. $O$ crescimento inadequado trouxe consequências a estas áreas, como: serviços públicos deficitários, danos ao meio ambiente, serviços inadequados de habitação, saneamento, água e esgoto e sobrecarga da infraestrutura existente (MOTA, 1999). Neste sentido, nota-se que muitos bairros periféricos da cidade, constituídos a partir do aumento do fluxo migratório entre os anos de 1970 a 1990, são acometidos por diversos problemas sociais e ambientais (GIGLIOTTI; SANTOS, 2013).

A reorganização da Atenção Básica no município de Caraguatatuba iniciou-se em 1998, com implantação da ESF, num contexto em que o Ministério da Saúde incrementou o valor de incentivo financeiro repassado aos municípios. Em documento que avalia a implantação da Saúde da Família, entre os anos 1998 e 2004, o Ministério da Saúde indica maior cobertura da ESF quanto menores os municípios e sua renda per capita (BRASIL, 2006b).

O Departamento de Atenção Básica, ligado à Secretaria Municipal de Saúde (SMS) é responsável pela gestão da ESF em parceria com o Instituto Corpore, que atua no município desde maio de 2014. O Instituto Corpore atua no gerenciamento, supervisão e operacionalização das atividades da ESF do município, além de ser 
responsável pela contratação de parte dos funcionários. O quadro abaixo apresenta a composição das equipes que compõem as equipes de saúde da Atenção Básica do município.

Quadro 1 - Composição das equipes das unidades de saúde da Atenção Básica

\begin{tabular}{|c|c|}
\hline Unidades de Saúde & Composição por equipe \\
\hline $\begin{array}{l}1 \text { UPA (Unidade de Pronto } \\
\text { Atendimento) }\end{array}$ & $\begin{array}{l}\text { Enfermeiros, auxiliares e técnicos de enfermagem } \\
\text { plantonistas; médicos ( } 29 \text { clínicos, } 12 \text { cirurgiões gerais, } 7 \\
\text { ortopedistas, } 4 \text { oftalmologistas, } 2 \text { psiquiatras } 4 \\
\text { ultrassonografistas, } 11 \text { pediatras, } 2 \text { neurologistas). }\end{array}$ \\
\hline 11 UBS & $\begin{array}{l}\text { Profissionais diversos, que variam segundo a UBS, como } \\
\text { pediatra, oftalmologista, psicólogo, fisioterapeuta etc. }\end{array}$ \\
\hline 20 USF & $\begin{array}{l}1 \text { médico, } 1 \text { enfermeiro, } 2 \text { auxiliares de enfermagem e } 6 \text { ACS; } \\
1 \text { cirurgião dentista, } 1 \text { auxiliar de consultório dentário e } 1 \\
\text { auxiliar administrativo. }\end{array}$ \\
\hline $\begin{array}{l}2 \text { PACS (Programa de Agente } \\
\text { Comunitário de Saúde). }\end{array}$ & Cada PACS com 6 ACS, lotados na região central. \\
\hline
\end{tabular}

Fonte: o autor - a partir de entrevista realizada e dados disponíveis no site oficial do município.

As equipes do PACS estão localizadas na região central da cidade, em função do menor grau de vulnerabilidade deste território. As equipes de saúde da família distribuem-se pelas demais localidades do município, prioritariamente nas regiões de maior vulnerabilidade. As equipes de saúde da família ocupam o mesmo prédio das UBSs, sendo que algumas UBSs contam com até 4 equipes. A ESF tem cobertura de cerca de $80 \%$ da população. O profissional responsável pela gestão e supervisão do trabalho das equipes é a enfermeira das equipes de saúde da família. Além disso, todas as UBSs do município contam com profissional com função específica de gestor, que oferece apoio às equipes de saúde da família localizadas no mesmo espaço físico. Os profissionais das equipes são contratados através de concurso público, realizado pela prefeitura, e através de contratos temporários, pelo Instituto Corpore. 


\section{Unidades e sujeitos da pesquisa}

Participaram do estudo 8 equipes de saúde da família, distribuídas em duas Unidades Básicas de Saúde (UBS). A amostra pesquisada contou com representantes de todas as categorias profissionais que compõem as equipes da ESF: agentes comunitários de saúde (ACS), auxiliares de enfermagem (AUX ENF), enfermeiros (ENF) e médicos (MED). As características dos participantes são apresentadas no quadro abaixo:

Quadro 2 - Composição da amostra pesquisada

\begin{tabular}{|c|c|}
\hline Participantes & Observações Gerais \\
\hline 24 ACS & $\begin{array}{l}21 \text { mulheres e } 3 \text { homens } \\
\text { Faixa etária de } 21 \text { a } 55 \text { anos } \\
22 \text { com ensino médio completo; } 2 \text { graduados. A maioria foi contratada há } 3 \text { anos, } \\
\text { por ocasião da realização de concurso público }\end{array}$ \\
\hline 5 AUX ENF & $\begin{array}{l}4 \text { mulheres e } 1 \text { homem } \\
\text { Faixa etária de } 30 \text { a } 50 \text { anos } \\
\text { Recém contratados e profissionais com maior tempo de trabalho na ESF }\end{array}$ \\
\hline 8 ENF & $\begin{array}{l}\text { Todas mulheres } \\
\text { Faixa etária de } 25 \text { a } 35 \text { anos } \\
\text { Grupo heterogêneo quanto a tempo de formação e experiência na ESF }\end{array}$ \\
\hline 7 MED & $\begin{array}{l}4 \text { mulheres e } 3 \text { homens } \\
\text { Faixa etária de } 30 \text { a } 60 \text { anos } \\
\text { Dentre os médicos haviam } 5 \text { profissionais advindos de Cuba, recém contratados } \\
\text { pelo Programa Mais Médicos, do Governo brasileiro }\end{array}$ \\
\hline
\end{tabular}

\subsection{Breve revisão sobre metodologia}

Considera-se fundamental para o desenho do projeto da pesquisa, ou seja, para seleção dos métodos e instrumentos de coletas de dados, o discernimento a respeito dos propósitos do estudo (NEUMAN, 2007; MARSHALL; ROSSMAN, 1995). 
Como assinalado, o presente estudo objetiva investigar como a organização e as condições do trabalho influenciam na utilização de recursos não materiais pelas equipes da ESF. Esta pesquisa caracteriza-se como exploratória, considerando-se:

- As pesquisas sobre recursos concentrarem-se, quase que exclusivamente, nas organizações privadas. Sendo assim, a análise de uma organização pública compreende algo com desenvolvimento ainda incipiente;

- A maior parte das pesquisas sobre o papel dos recursos se limita à investigação sobre recursos tangíveis;

- Por se tratar de um modelo novo, a ESF constitui um contexto pouco explorado na produção científica da área de engenharia de produção e gestão de operações.

Segundo Ganga (2012), o foco da pesquisa exploratória é revelar novos aspectos a respeito do fenômeno observado. Neste caso, não há compromisso com a descoberta ou comprovação de uma teoria em específico, mas sim de explorar o fenômeno em si, revelando, por exemplo, suas perspectivas e particularidades.

Considerando a melhor adequação ao objeto de estudo, optou-se pela abordagem qualitativa, a qual:

- Tem caráter interpretativo e indutivo. De forma distinta da pesquisa quantitativa - centrada em um conjunto definido de variáveis, com foco na mensuração, no conhecimento estatístico e matemático - a pesquisa qualitativa busca descrever os detalhes da situação, explorando questões como: quem disse o que? Quando? Como? Onde e por quê? Possibilita investigarmos como teorias e conceitos operam em casos particulares (GEPEHART, 2004);

- Possui quadro teórico e hipóteses menos estruturadas que a abordagem quantitativa e, dessa forma, permite focarmos na perspectiva do indivíduo, considerando sua subjetividade. Além disso, propicia, por meio da observação e coleta de evidências, a interpretação do ambiente no qual a problemática está inserida (MARTINS, 2010);

- É sensível à imprevisibilidade e, dessa forma, capaz de adaptar-se à natureza do contexto social investigado (CASSELL et. al, 2009);

- Compreende um amplo intervalo de alcance no tempo, opera com variáveis complexas e de difícil mensuração e, finalmente, permite a utilização de 
múltiplas fontes de dados (documentos, artefatos físicos, entrevistas, registros em arquivos e observações direta e participante) (BRYMAN, 1989; BURNS, 2000, YIN, 2010)

Segundo Martins (2010), na área de engenharia de produção e gestão de operações, os métodos de pesquisa mais adequados para realizar pesquisas qualitativas são o estudo de caso e a pesquisa-ação. Estudo realizado por Berto e Nakano (2000), que envolveu análise da produção científica presente nos anais do Encontro Nacional de Engenharia de Produção - ENEGEP - de 1996 a 1998, corrobora com Martins (2010) ao indicar que o estudo de caso é o método de pesquisa mais utilizado na área de conhecimento da engenharia de produção. No entanto, segundo esses autores, uma análise mais cuidadosa dos trabalhos indica que ainda há muitas debilidades nas produções, principalmente na compreensão do real significado da condução de um estudo de caso.

Com base na literatura (BERTO; NAKANO, 2000; GIL, 1996; MIGUEL, 2010; YIN, 2010), considera-se o estudo de caso como: a) uma pesquisa de caráter empírico, que pode se pautar em evidências qualitativas e quantitativas; b) que investiga certo fenômeno contemporâneo, inserido em um contexto real, por meio de análise aprofundada de um ou mais objetos de análise, com intuito de obter um amplo e detalhado conhecimento sobre eles; e c) que se aplica particularmente nas ocasiões sobre as quais o pesquisador tem pouco ou nenhum controle e quando as fronteiras entre o fenômeno e o contexto não estão claramente delimitadas.

Como na presente pesquisa busca-se contribuir para uma melhor compreensão de um fenômeno contemporâneo, cujas fronteiras com o contexto não são claras, adotou-se o estudo de caso como método de pesquisa.

Segundo Yin (2010), a dificuldade presente na investigação realizada por meio de um estudo de caso, em discernir entre o fenômeno e o contexto, a submete a uma situação tecnicamente única: há mais variáveis de interesse do que fontes de dados específicas sobre o problema de pesquisa. Para o pesquisador, esta situação singular implica na necessidade de basear-se em múltiplas fontes de evidências (triangulação) para validação dos constructos e de desenvolver previamente proposições teóricas que auxiliarão na condução da coleta e análise dos dados. Com relação aos constructos, Ganga (2012) destaca que o estudo de caso também se baseia em um modelo teórico-conceitual, mas que, no entanto, não deve ser considerado de maneira 
rígida e imutável, como na abordagem quantitativa. Dessa forma, para o autor, a própria interação do pesquisador com a problemática de pesquisa pode conduzi-lo ao aprendizado e, consequentemente, à revisão dos construtos adotados, incorporando ou removendo novos constructos ao modelo teórico-conceitual inicial.

Para Miguel (2007) uma etapa importante para a condução de um estudo de caso é o planejamento do(s) caso(s). Uma das primeiras tarefas dessa etapa é seleção da(s) unidade(s) de análise, isto é, do(s) caso(s). Yin (2010) e Voss et al (2002) classificam os estudos de casos em únicos e múltiplos. Segundo os autores, o estudo de casos múltiplos apresenta maior grau de generalização e é mais consistente do que o estudo de caso único, pois apresenta maior convergência de observações e minimiza o viés do observador. No entanto, explora cada um dos casos em menor profundidade e demanda maiores recursos e tempo para sua consecução do que o estudo de caso único - que é muito utilizado em pesquisas longitudinais.

Considerando as especificidades do objeto de pesquisa e as potencialidades e fragilidades dos dois tipos de estudo de caso apresentados, optou-se pela realização de estudo de caso único (a ESF no município de Caraguatatuba).

Findada a etapa da seleção dos casos, inicia-se o estágio de determinação dos métodos e técnicas para a coleta e análise dos dados. Dentre as opções apresentadas por Yin (2010) como fonte de evidências, utilizou-se nesta pesquisa: a revisão bibliográfica, a observação direta e o grupo focal. Segundo Eisenhardt (1989), a presença de múltiplas fontes de evidências e a iteração com os constructos (que são fruto da etapa de revisão da literatura) proporciona maior validade construtiva à pesquisa.

Para consecução da coleta de dados, adotou-se a observação direta de caráter exploratório e, como instrumento principal, o grupo focal. Esta técnica, associada à pesquisa qualitativa e entrevistas grupais, auxilia na compreensão de percepções, atitudes e representações sociais (MORGAN, 1997). Gatti (2005) salienta, no entanto, que a opção pelo grupo focal necessita ser criteriosa, coesa e integrada ao corpo da pesquisa, sobretudo aos objetivos do estudo.

O cerne do grupo focal é, precisamente, a interação entre os membros do grupo e o pesquisador (LEVORLINO; PELICIONI, 2001). Por meio desta essência interativa, o grupo focal proporciona, simultaneamente, ao pesquisador um espaço de 
coleta de dados e aos constituintes do grupo um ambiente de reflexão sobre suas concepções (SILVA et. al., 2013). A relação entre os presentes no grupo, o ouvir e expressar-se, a complementação ou contraposição de ideias, fornece informações e "sentidos" muitas vezes inacessíveis fora deste contexto (BANCHS, 2005). Assim, a adoção do grupo focal possibilita a compreensão de ideias compartilhadas e, além disso, a visualização de como os indivíduos influenciam-se mutuamente (GATTI, 2005).

Gatti (2005) destaca, ainda, que o trabalho com grupo focal obtém dados que vão além das respostas simplistas, das racionalizações tipificantes e de explicações superficiais e, por esse motivo, apresenta bons resultados para estudos de situações com alto grau de complexidade, temas polêmicos, contraditórios, atrelados a autoritarismos, preconceitos, rejeições, angústias ou temor de retaliações.

Por último, procedeu-se ao tratamento dos dados, momento em que os dados advindos das diferentes fontes e casos foram examinados, categorizados e tabulados, buscando-se propor generalizações (YIN, 2010; EISENHARDT, 1989).

\subsection{Delineamento metodológico}

\section{Metodologia de coleta de dados}

Após autorização da responsável pela atenção básica do município estudado, o pesquisador entrou em contato com os responsáveis/gestores por cada unidade de saúde pesquisada. Neste primeiro contato, descreveu os objetivos, etapas e técnicas necessárias para a realização da pesquisa. A seguir, realizou um primeiro encontro com as equipes, forneceu as informações sobre a pesquisa e solicitou consentimento formal para iniciar o estudo, por meio do Termo de Consentimento Livre e Esclarecido.

No presente estudo, totalizou-se a participação de oito equipes de Estratégia Saúde da Família, sendo quatro da UBS A e quatro da UBS B. Participaram do estudo todas as categorias profissionais que compõem as equipes: agentes comunitários de saúde, auxiliares de enfermagem, enfermeiros e médicos. Iniciou-se, então, a coleta 
de dados, que envolveu duas etapas: 1) observação do funcionamento das equipes e unidades; 2) condução dos grupos focais.

\section{Etapa 1: observação direta, não participante}

Esta etapa consistiu em observar aspectos gerais da organização e funcionamento das equipes, como, por exemplo, as relações entre seus membros, experiências e níveis hierárquicos, bem como examinar como temas relevantes para a produção do cuidado eram abordados. Esta etapa permitiu que os participantes se familiarizassem com a presença do pesquisador, de maneira a facilitar a realização da etapa seguinte, que correspondeu aos grupos focais. As observações se deram principalmente através do acompanhamento das reuniões das equipes participantes do estudo. Foram observadas três reuniões de cada equipe, totalizando-se 24 reuniões.

No primeiro dia de observação, o pesquisador retomou resumidamente os objetivos, métodos e técnicas que seriam utilizados e esclareceu as dúvidas dos participantes a respeito do desenvolvimento da pesquisa. Expos, a seguir, que a fase em andamento adotava como técnica a observação não participante, uma vez que visava compreender o funcionamento das reuniões de equipe em condição natural, com a mínima interferência do pesquisador. Assim, orientou que agissem o mais naturalmente possível, ignorando sua presença. Destaca-se que no segundo e terceiro encontro, os participantes estavam mais à vontade. Ao término de cada reunião, uma síntese das observações, impressões e ideias foi registrada em diário de campo. Uma análise preliminar dos dados obtidos nesta fase serviu de base para a definição dos temas e questões que compuseram os disparadores dos debates dos grupos focais.

\section{Etapa 2: Grupos focais}

Para a consecução dos grupos focais, foi adotado uma configuração de no mínimo 4 e no máximo 15 participantes por grupo, com o objetivo de garantir uma 
efetiva participação de todos e a discussão satisfatória dos temas propostos. Foram constituídos quatro grupos, sendo dois com participantes que ocupavam cargos de nível superior (enfermeiros e médicos) e dois com participantes que ocupavam cargos de nível médio e técnico ${ }^{7}$ (auxiliares de enfermagem e agentes comunitários de saúde). Essa composição propiciou, simultaneamente, ajustar-se ao critério numérico de participantes sugerido pela literatura e assegurar uma participação menos influenciada pela hierarquia entre profissionais. Ainda com objetivo de facilitar a participação, todas as sessões dos grupos focais foram realizadas no espaço físico onde as equipes atuavam. O quadro abaixo apresenta a composição dos grupos:

Quadro 3 - Composição dos grupos focais

\begin{tabular}{|c|c|c|}
\hline Unidade de saúde/equipes & $\begin{array}{c}\text { Nome e composição do } \\
\text { grupo }\end{array}$ & Número de participantes \\
\hline \multirow{2}{*}{ UBS A / equipes $1,2,3$ e 4} & Grupo 1. ACS e Aux. Enf. & 15 (12 ACS / 3 Aux) \\
\hline & Grupo 2. Enf. e Méd. & 7 (4 Enf / 5 Méd) \\
\hline \multirow{2}{*}{ UBS B / equipes 5, 6, 7 e 8} & Grupo 3. ACS e Aux. Enf. & 14 (12 ACS / 2 Aux) \\
\hline & Grupo 4. Enf. e Méd. & 6 (4 Enf / 2 Méd) \\
\hline
\end{tabular}

Os dois primeiros encontros dos grupos foram destinados ao debate de temas suscitados pelo pesquisador e o terceiro à validação dos dados obtidos nos encontros anteriores. Os encontros tiveram duração média de uma hora e trinta minutos e foram registrados em áudio. No primeiro e segundo encontro de cada grupo, foi utilizado roteiro com, respectivamente, 5 e 6 questões abertas, que serviram de norteadoras para as discussões. Além de focalizarem os aspectos estudados, as questões buscaram incentivar trocas aprofundadas. O pesquisador buscou garantir um ambiente agradável, descontraído e propício ao debate e a reflexão. Após cada encontro, o pesquisador anotava em diário de campo suas impressões e ideias, bem como quaisquer complementações para os próximos encontros.

\footnotetext{
${ }^{7}$ Embora o cargo não exigisse, alguns agentes comunitários de saúde e auxiliares de enfermagem estavam cursando ou haviam concluído curso de nível superior.
} 


\section{Primeiro encontro}

Iniciado com uma sessão de apresentação e esclarecimentos. O pesquisador expôs seu papel como moderador do grupo, os objetivos específicos do encontro e justificou a configuração dos grupos. A anuência para o registro das discussões foi requisitada, enfatizando-se o compromisso com o sigilo e a garantia de anonimato dos participantes. Em seguida, deu-se o debate dos temas norteadores, tendo como objetivo explorar aspectos relativos ao processo de trabalho e identificar os recursos que os profissionais consideravam importantes para a efetiva produção do cuidado. Nesse encontro, não foram apresentadas questões diretas (Anexo 1) sobre o tema recursos de modo a evitar respostas lacônicas e/ou induzidas.

A abordagem sobre recursos, no primeiro momento, foi construída por meio de questão norteadora que conduziu os profissionais a referirem-se ao conceito sem serem, no entanto, indagados diretamente sobre o mesmo. Este aporte foi adotado com a intenção de evitar o direcionamento do debate, durante a realização das sessões grupais. A presença do termo "recurso" na questão que direcionaria o debate, poderia, por exemplo, conduzir os depoimentos na direção da concepção mais convencional do tema, concebendo-o unicamente como recurso material. Nesta perspectiva, a questão utilizada para iniciar a discussão sobre o tema foi o que é necessário para o trabalho de vocês surtir o efeito desejado?

O material proveniente deste encontro foi retomado pelo pesquisador durante o intervalo que antecedeu o segundo e terceiro encontros, servindo de base para a preencher o Quadro de Categorização de Recursos (QCR) - cuja construção é apresentada mais adiante. Neste Quadro ${ }^{8}$, os recursos identificados pelos profissionais como mais relevantes para a produção do cuidado na ESF encontramse organizados e classificados.

\section{Segundo Encontro}

Neste encontro, o tema recursos foi abordado através de questões diretas (Anexo 2). Uma das questões consistiu em debater o quadro de recursos identificados

\footnotetext{
${ }^{8}$ Este quadro foi construído com base nos trabalhos de Mills, Platts e Bourne (2003) e de Valentin (2001).
} 
no encontro anterior. Os participantes foram questionados sobre suas percepções a respeito da distribuição destes recursos entre as categorias materiais e imateriais. Solicitou-se que eles complementassem a lista com outros recursos que jugassem importantes. O objetivo deste encontro foi visualizar o lugar ocupado pelos recursos imateriais no processo de trabalho. Foram exploradas a concepção de recursos dos trabalhadores e as dificuldades relatadas para desenvolvimento dos recursos imateriais (principalmente vínculo, acolhimento e confiança).

No intervalo que antecedeu o último encontro (entre duas e três semanas para cada grupo) foram realizadas a transcrição e a análise preliminar do material proveniente dos encontros precedentes, o que originou as primeiras considerações do pesquisador a respeito dos temas debatidos. Além disso, os recursos citados pelos trabalhadores foram acrescentados ao QCR.

\section{Terceiro encontro}

Um resumo da análise e das considerações preliminares do pesquisador foi apresentado aos participantes da pesquisa. O QCR, construído a partir dos recursos identificados no primeiro e segundo encontro dos grupos foi apresentado aos profissionais, de maneira a proceder a validação das informações obtidas. Durante este último encontro, o pesquisador teve oportunidade de aprofundar o debate sobre os temas mais relevantes, sanar possíveis dúvidas quanto a apontamentos dos grupos e, principalmente, realizar uma validação dos dados de sua análise preliminar. Os registros de áudio deste encontro também foram transcritos. ${ }^{9}$

\section{Construção do Quadro de Categorização de Recursos}

Para identificação dos recursos avaliados como fundamentais para a produção do cuidado na ESF, foi utilizado como referencial metodológico a categorização de

\footnotetext{
${ }^{9}$ Com o propósito de manter o anonimato, nas transcrições o nome de cada participante da pesquisa foi substituído por um código composto pelas iniciais da categoria profissional a que pertencia, seguido de um algarismo numérico, atribuído segundo a ordem com que se deu sua participação no grupo. Assim, por exemplo, o agente comunitário de saúde que foi o terceiro a manifestar-se foi chamado ACS 3 , a primeira enfermeira a falar foi chamada ENF 1 e assim por diante.
} 
recursos presentes no estudo a respeito da identificação e avaliação de recursos e competências, de autoria de Mills, Platts e Bourne (2003) e a categorização de Valentin (2001) - apresentadas no segundo capítulo. Apresenta-se no quadro abaixo a nomenclatura da categorização adotada, bem como as categorias correspondentes nos estudos de referência.

Quadro 4 - Quadro de categorização de recursos

\begin{tabular}{|c|c|c|c|}
\hline & Categorias adotadas & $\begin{array}{l}\text { Categoria em } \\
\text { Mills, Platts e } \\
\text { Bourne }\end{array}$ & $\begin{array}{l}\text { Categoria em } \\
\text { Valentin }\end{array}$ \\
\hline \multirow[b]{2}{*}{$\begin{array}{l}\text { Recursos } \\
\text { tangíveis }\end{array}$} & 1. Equipamentos e materiais; & "tangíveis" & "financeiro" \\
\hline & $\begin{array}{l}\text { 2. Sistema e recursos processuais } \\
\text { (documentos, sistemas de } \\
\text { recrutamento, seleção, avaliação, } \\
\text { sistemas de computadores). }\end{array}$ & $\begin{array}{l}\text { "Sistema e } \\
\text { recursos } \\
\text { processuais" }\end{array}$ & - \\
\hline \multirow{5}{*}{$\begin{array}{l}\text { Recursos } \\
\text { intangíveis }\end{array}$} & $\begin{array}{l}\text { 3. Humano - conhecimento, } \\
\text { habilidades e experiência dos } \\
\text { profissionais. }\end{array}$ & $\begin{array}{l}\text { "recursos de } \\
\text { conhecimento, } \\
\text { habilidades e } \\
\text { experiência" }\end{array}$ & "humano" \\
\hline & $\begin{array}{l}\text { 4. Organizacional - valores culturais, } \\
\text { costumes, visões compartilhadas, } \\
\text { valores, rotinas e relações de } \\
\text { trabalho. }\end{array}$ & $\begin{array}{l}\text { "recursos e } \\
\text { valores culturais" }\end{array}$ & "organizacional" \\
\hline & $\begin{array}{l}\text { 5. Reputacional - memória de } \\
\text { situações passadas, como a } \\
\text { organização é vista pelo usuário } \\
\text { (valor simbólico). }\end{array}$ & $\begin{array}{l}\text { "recursos das } \\
\text { relações" }\end{array}$ & "reputacional” \\
\hline & $\begin{array}{l}\text { 6. Relações - grupos de interesses } \\
\text { que envolvem a organização } \\
\text { (usuários, gestores, supervisores, } \\
\text { outras organizações). }\end{array}$ & $\begin{array}{l}\text { "recursos das } \\
\text { relações" }\end{array}$ & "relacional" \\
\hline & $\begin{array}{l}\text { 7. Informacional - informações sobre os } \\
\text { usuários e a rede de serviços. }\end{array}$ & - & "informacional" \\
\hline
\end{tabular}

Fonte - o autor - com base em Mills, Platts e Bourne (2003) e Valentin (2001).

A junção das categorias desses autores permitiu trabalhar com uma categorização mais adequada ao estudo, pois envolve definição mais abrangente permitindo alcançar determinadas nuances do objeto estudado - e nomenclatura mais objetiva. Dessa maneira, por exemplo, as categorias "reputacional" e "relacional" correspondem a uma única categoria na tipologia de Mills, Platts e Bourne (2003), especificamente "recursos das relações". 
Apesar da análise centrar-se sobre os recursos intangíveis, será realizada uma identificação geral dos recursos (tangíveis e intangíveis) avaliados como fundamentais para o processo de trabalho na ESF.

\section{Metodologia para organização e análise dos dados}

Os dados provenientes de áudio e de diário de campo foram transcritos e, em seguida, tabulados. As informações provenientes das observações realizadas nas unidades estudadas foram organizadas em um quadro com o resumo do funcionamento de cada equipe estudada segundo alguns aspectos fundamentais, tais como: organização e processo de trabalho; relações entre trabalhadores e hierarquia; rotatividade; relação com a população. Esses dados serviram de base para a construção dos roteiros norteadores dos grupos. Para a análise dos dados originados dos 12 encontros de grupo, utilizou-se uma adaptação da abordagem restaurativa em saúde, referenciada nos trabalhos de Marck (2006), Creswell (2009) e Gimenes (2011). Com base nesta abordagem, a análise foi construída a partir de uma sequência de etapas interativas, conforme figura abaixo:

Figura 2 - Abordagem interativa para análise e discussão dos dados

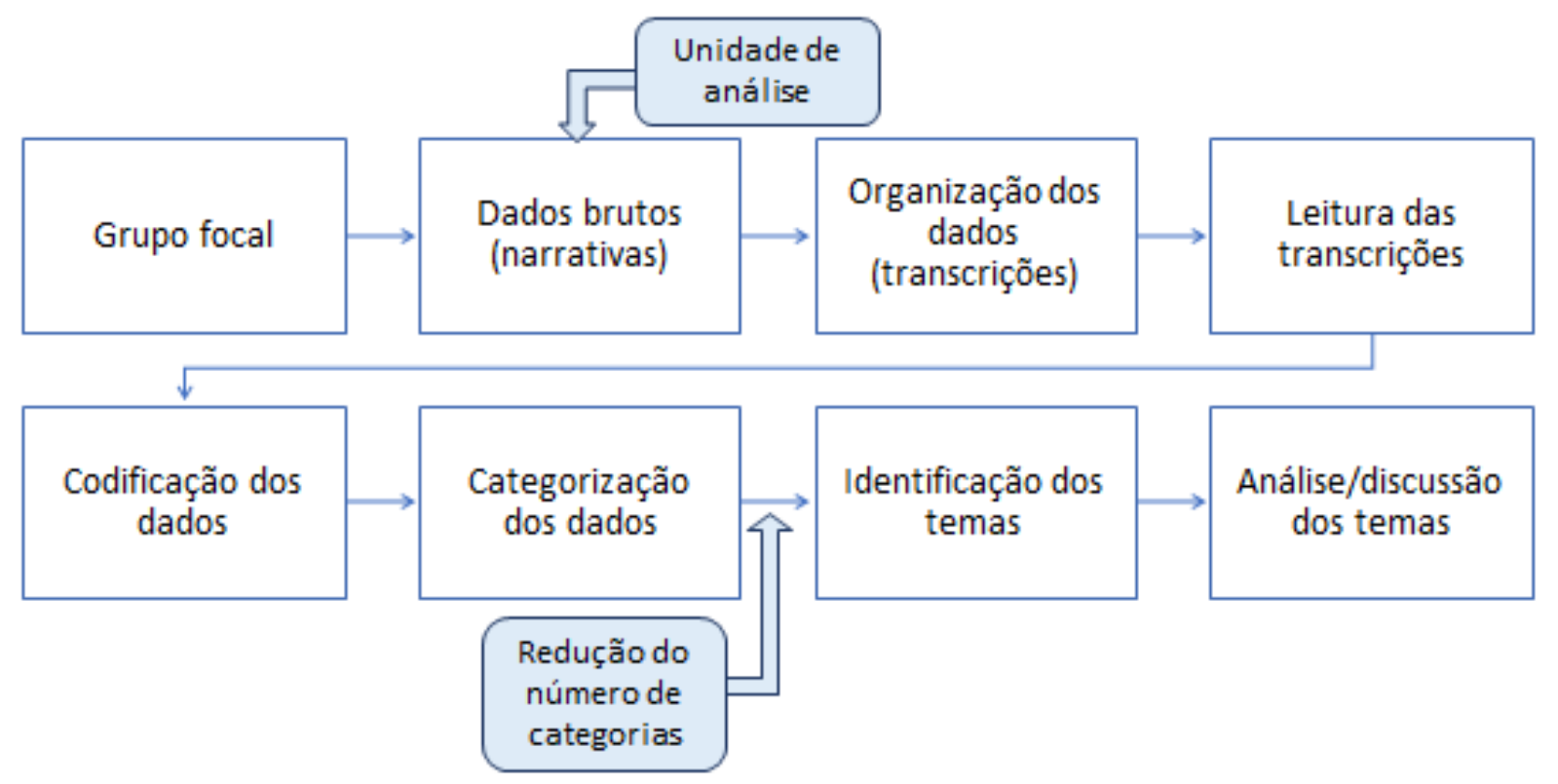


De posse das transcrições dos encontros, foi realizada uma leitura atenciosa das mesmas, identificando relações entre os dados e os objetivos da pesquisa. Em uma segunda leitura, foram destacados os trechos relevantes para os objetivos. A seguir, a partir desses trechos, deu-se início a etapa de codificação dos dados, atribuindo um código a cada fala ou conjunto de falas dos participantes que abordavam um mesmo conteúdo. Os códigos foram dispostos em um quadro (conforme exemplo - Quadro 5) de maneira a possibilitar uma efetiva organização das informações e garantir que, a qualquer momento da pesquisa, as falas que deram origem a eles pudessem ser retomadas. Esta etapa prosseguiu até que se esgotaram as informações relevantes aos objetivos do estudo, sendo totalizados ao final 526 códigos.

Quadro 5 - Exemplo de criação de códigos, a partir de uma fala ou conjunto de falas relacionadas

\begin{tabular}{|c|c|c|c|c|}
\hline Trecho da transcrição & Nome do código & $\begin{array}{c}\mathrm{N}^{\circ} \\
\text { código }\end{array}$ & $\mathrm{N}^{\circ}$ página & Grupo \\
\hline $\begin{array}{l}\text { "Falta de vontade de outros profissionais. } \\
\text { Falta de apoio. Falta de solidariedade" } \\
\text { ACS } 4\end{array}$ & \multirow{3}{*}{$\begin{array}{l}\text { Sentindo que há } \\
\text { falta de vontade e } \\
\text { apoio de outros } \\
\text { profissionais }\end{array}$} & \multirow{3}{*}{1} & 1 & $\begin{array}{c}1 \mathrm{ACS} \text { e } \\
\text { AUX }\end{array}$ \\
\hline $\begin{array}{l}\text { "A gente trabalha, trabalha e somos } \\
\text { vistas como mais um só, você faz a sua } \\
\text { parte e vem outro e não faz." ACS } 1\end{array}$ & & & 9 & $\begin{array}{c}2 \text { ACS e } \\
\text { AUX }\end{array}$ \\
\hline $\begin{array}{l}\text { “...que na verdade, assim, a gente corre } \\
\text { para trabalhar, dá o sangue, faz tudo } \\
\text { para trabalhar e quando chega lá, parece } \\
\text { que nosso serviço foi tudo por água } \\
\text { abaixo..." ENF } 4\end{array}$ & & & 10 & $\begin{array}{c}2 \text { ENF e } \\
\text { MED }\end{array}$ \\
\hline
\end{tabular}

Os códigos obtidos foram agrupados, resultando em 177 categorias (conforme exemplo do Quadro 6), as quais reagrupadas, também com base nas similaridades, foram reduzidas a um conjunto de 22 novas categorias mais amplas - organizadas em quadro síntese (conforme exemplo - Quadro 7). 
Quadro 6 - Exemplo de criação de categorias, a partir do agrupamento de códigos relacionados

\begin{tabular}{|c|c|c|}
\hline $\begin{array}{c}N^{\circ} \\
\text { Código }\end{array}$ & Código & Categoria \\
\hline 2 & Percebendo a falta de funcionários & \multirow{7}{*}{$\begin{array}{l}\text { 1. Identificando a } \\
\text { falta de } \\
\text { funcionários } \\
\text { na unidade }\end{array}$} \\
\hline 5 & $\begin{array}{l}\text { Percebendo falta de funcionários da área de auxiliar de } \\
\text { enfermagem }\end{array}$ & \\
\hline 19 & Percebendo falta de funcionários da área de medicina & \\
\hline 29 & Sentindo a redução no número de funcionários & \\
\hline 56 & Percebendo a necessidade de ter mais profissionais & \\
\hline 253 & $\begin{array}{l}\text { Percebendo a falta de funcionários da área administrativa } \\
\text { na recepção da UBS }\end{array}$ & \\
\hline 466 & Sentindo falta de funcionários, especificamente de ACS & \\
\hline 30 & $\begin{array}{l}\text { Sentindo dificuldades em realizar atividades em função da } \\
\text { redução do número de funcionários }\end{array}$ & \multirow{2}{*}{$\begin{array}{l}\text { 2. Notando as } \\
\text { consequências } \\
\text { da redução no } \\
\text { número de } \\
\text { funcionários }\end{array}$} \\
\hline 181 & $\begin{array}{l}\text { Sentindo piora na organização da unidade, em função da } \\
\text { redução do número de funcionários }\end{array}$ & \\
\hline
\end{tabular}

Quadro 7 - Exemplo de definição de categorias mais amplas, a partir do agrupamento de categorias relacionadas

\begin{tabular}{c|l|c}
\hline $\begin{array}{c}\text { No } \\
\text { Categoria }\end{array}$ & \multicolumn{1}{|c|}{ Categoria } & Categoria Reduzida \\
\hline 1 & Identificando a falta de funcionários na unidade & $\begin{array}{c}\text { 1. Sobre } \\
\text { funcionários: } \\
\text { carência }\end{array}$ \\
\hline \hline 81 & Identificando a falta de profissionais especialistas & \multirow{2}{*}{$\begin{array}{c}\text { 2. Sobre } \\
\text { funcionários: } \\
\text { consequências } \\
\text { de sua carência }\end{array}$} \\
\hline 59 & $\begin{array}{l}\text { Notando as consequências da redução no número de } \\
\text { funcionários }\end{array}$ & Observando as consequências da troca de funcionários \\
\hline 157 & Observando as consequências da falta de funcionários & \multicolumn{1}{|c}{} \\
\hline \hline
\end{tabular}


O passo seguinte compreendeu a etapa de definição de temas, criados a partir do reagrupamento das 22 categorias definidas na etapa anterior (conforme exemplo abaixo - Quadro 8). Ao final dessa etapa foram obtidos sete temas (Anexo 5), sendo escolhidos para análise os cinco que se mostraram diretamente relacionados aos objetivos de pesquisa.

Quadro 8 - Exemplo de definição de temas, a partir do agrupamento de categorias relacionadas

\begin{tabular}{|c|c|c|}
\hline $\begin{array}{l}\text { No Categoria } \\
\text { Reduzida }\end{array}$ & Categoria Reduzida & Tema \\
\hline 1 & Sobre funcionários: a carência & \multirow{5}{*}{$\begin{array}{l}\text { 1. Concebendo } \\
\text { recursos e } \\
\text { debatendo a } \\
\text { ausência de } \\
\text { recursos } \\
\text { materiais e não } \\
\text { materiais }\end{array}$} \\
\hline 2 & $\begin{array}{l}\text { Sobre funcionários: as consequências de sua } \\
\text { carência }\end{array}$ & \\
\hline 3 & Sobre recursos: a carência & \\
\hline 4 & $\begin{array}{l}\text { Sobre recursos: consequências de sua oferta e } \\
\text { carência }\end{array}$ & \\
\hline 5 & $\begin{array}{l}\text { Concepção e considerações sobre recursos materiais } \\
\text { e não materiais }\end{array}$ & \\
\hline 6 & $\begin{array}{l}\text { Considerações sobre os trabalhos de orientação e } \\
\text { prevenção }\end{array}$ & \multirow{3}{*}{$\begin{array}{l}\text { Concebendo o } \\
\text { modelo, o foco } \\
\text { de atuação e os } \\
\text { parâmetros de } \\
\text { avaliação }\end{array}$} \\
\hline 13 & $\begin{array}{l}\text { Sobre a avaliação do modelo, do serviço e dos } \\
\text { trabalhadores }\end{array}$ & \\
\hline 18 & Concepção do modelo e suas decorrências & \\
\hline
\end{tabular}




\section{ANÁLISE E DISCUSSÃO DOS DADOS}

A análise versará sobre o conjunto dos dados obtidos a partir dos encontros realizados com os quatro grupos de profissionais - descritos no capítulo precedente. Os dados relativos à observação participante serviram para fundamentar parte das informações fornecidas pelos profissionais.

\subsection{Tema 1: Concebendo recursos e debatendo a ausência de recursos materiais e não materiais}

Este tema compreende as seguintes categorias: concepção e considerações dos profissionais sobre recursos materiais e não materiais; carência de recursos; consequências atreladas aos recursos; carência de profissionais; e consequências da carência de funcionários. A análise destas categorias foi realizada a partir da abordagem de três pontos: concepção de recurso dos profissionais, identificação dos recursos considerados essenciais para a ESF e consequências da fragilidade ou da falta desses recursos. Primeiro, apresenta-se uma análise geral do Quadro de Categorização de Recursos e, a seguir, dos pormenores dos encontros - momento em que alguns itens do quadro são retomados.

\section{Análise do Quadro de Categorização de Recursos (QCR)}

Quadro 9 - Identificação e categorização de recursos

\begin{tabular}{|c|c|c|}
\hline & Tipos de recursos & Recursos identificados \\
\hline \multirow[t]{2}{*}{ Tangíveis } & 1. Equipamentos e materiais & $\begin{array}{l}\text { Água destilada, aparelho de aferir pressão, } \\
\text { autoscópio, borracha, caneta, cartão de pré- } \\
\text { natal, estetoscópio, estrutura física, frasco } \\
\text { para coletar preventivo, lápis, luva, } \\
\text { medicamentos, mochila, papel sulfite, } \\
\text { prancheta, protetor solar, sonar, soro } \\
\text { glicosado }\end{array}$ \\
\hline & $\begin{array}{l}\text { 2. Sistema e recursos } \\
\text { processuais }\end{array}$ & $\begin{array}{l}\text { Prontuário informatizado; processo de } \\
\text { seleção e avaliação de profissionais }\end{array}$ \\
\hline
\end{tabular}




\begin{tabular}{|c|c|c|}
\hline \multirow{5}{*}{ Intangíveis } & 3. Humano & $\begin{array}{l}\text { Capacidade de aprender, capacidade de } \\
\text { resolver problemas, capacidade de trabalhar } \\
\text { em equipe, competência, conhecimento } \\
\text { técnico, escuta, ética, olhar humanizado, } \\
\text { profissionais }\end{array}$ \\
\hline & 4. Organizacional & $\begin{array}{l}\text { Autonomia, flexibilidade, } \\
\text { solidariedade entre instâncias }\end{array}$ \\
\hline & 5. Reputacional & $\begin{array}{l}\text { Confiança na organização, confiança no } \\
\text { serviço }\end{array}$ \\
\hline & 6. Relações & $\begin{array}{l}\text { Acolhimento, atenção, compreensão, } \\
\text { comprometimento/engajamento, } \\
\text { comunicação, confiança nas relações, } \\
\text { experiência, interesse, motivação, respeito, } \\
\text { responsabilidade, vínculo }\end{array}$ \\
\hline & 7. Informacional & Informações sobre usuários e serviços \\
\hline
\end{tabular}

Fonte - o autor, com base em Mills, Platts e Bourne (2003) e Valentin (2001).

A organização dos recursos identificados possibilitou um olhar mais abrangente sobre a maneira como são concebidos pelos trabalhadores, permitindo também reconhecer as relações entre os recursos. No quadro, os recursos tangíveis correspondem à tecnologia dura e os recursos intangíveis incluem as tecnologia levedura e leve.

A totalidade dos recursos materiais mencionados compreende recursos de baixa complexidade tecnológica, como previsto para este tipo de unidade, que compõe a atenção primária em saúde do SUS. Esses recursos cumprem papel de manutenção das condições de funcionamento das unidades, compreendendo materiais ligados às atividades de atendimento direto ao usuário, materiais de escritório, recursos que viabilizam as visitas domiciliares e a própria estrutura física da unidade.

Os demais recursos materiais citados, no item "sistema e recursos processuais" ${ }^{10}$, relacionam-se a dois tipos de necessidades apontadas pelos profissionais, sendo uma delas a de ter à disposição dados informatizados sobre os usuários (prontuário eletrônico) para otimizar os atendimentos. A outra necessidade consiste no aprimoramento do processo de seleção e avaliação dos profissionais.

10 Esta categoria de recursos compreende: documentos; sistemas de recrutamento, seleção e avaliação; e sistemas de computadores. 
Além de viabilizar a contratação de trabalhadores com perfil profissional mais condizente com as necessidades da ESF, este aprimoramento pode impactar positivamente no desenvolvimento de recursos não materiais essenciais para a produção do cuidado, como, por exemplo, acolhimento, vínculo e confiança.

Dentre os recursos imateriais do tipo "humano" citados pelos profissionais figura como recurso a competência. Ao mesmo tempo, foram citados como recursos aspectos encontrados na literatura que define o conceito de competência, tais como: capacidade de resolver problemas, conhecimento técnico e capacidade de aprender. Optou-se por mantê-los como recursos distintos, guardando a diferença com que eram concebidos pelos profissionais, ainda que no nível conceitual eles sejam mencionados como espécie de elementos constituintes da competência.

Quanto ao recuso autonomia, do tipo recurso "organizacional", sua discussão pelos profissionais ficou restrita a identificar os fatores externos que a limitavam, em detrimento da reflexão sobre os aspectos do trabalho sobre os quais a equipe tem maior grau de autonomia. As equipes precisam contar com certo grau de autonomia e de flexibilidade de seus profissionais, uma vez que necessitam assumir responsabilidades e estar aptos a conformarem a "solução ideal" para cada caso/usuário, acessando configurações específicas de recursos e tecnologias.

O recurso confiança foi citado nos itens "reputacional" e "relações". Este recurso pode ser analisado sob as perspectivas dos usuários e dos profissionais, que além de desenvolverem a confiança entre si, devem também confiar na organização. Para um desenvolvimento efetivo da confiança, há a necessidade de que ela se desenvolva nestas duas perspectivas. A confiança é de destacada relevância para a consecução dos objetivos da ESF, uma vez que em conjunto com acolhimento e vínculo forma um tripé da produção do cuidado. A ausência de qualquer um destes recursos inviabiliza o pleno desenvolvimento dos demais e, consequentemente, restringe as possibilidades de sucesso do modelo. Dessa forma, quando usuários, por exemplo, não confiam na organização, não há pleno desenvolvimento da confiança e haverá, consequentemente, barreiras à realização do acolhimento e a criação do vínculo.

Quanto aos recursos do tipo "relações", foram divididos em três subconjuntos, de acordo com sua relação mais estreita, respectivamente, com os recursos 
considerados centrais: acolhimento, vínculo e confiança. Assim, no subconjunto "Acolhimento" encontram-se os recursos atenção, compreensão, respeito, comunicação com usuário e escuta (que pertence ao item "humano"). No subconjunto "Confiança”, encontram-se experiência, interesse, responsabilidade, motivação e comunicação entre profissionais. E, finalmente, ao "Vínculo" ligam-se os recursos comprometimento, responsabilidade, motivação e comunicação com o usuário. Os recursos que compõem estes subconjuntos cumprem função de apoio para que aquele que dá nome ao conjunto se desenvolva. Assim, por exemplo, para um pleno desenvolvimento do recurso acolhimento, os demais recursos que compõem este subconjunto devem estar presentes na prática dos profissionais.

A respeito dos recursos "informações sobre usuários e serviços", único mencionado no tipo "informacional", compreendem as informações que os profissionais adquirem sobre o território de atendimento da UBS, a partir do contato cotidiano com a população atendida e com a rede de serviços. Estas informações, normalmente dispersas, quando sistematizadas passam a formar os recursos materiais do tipo "sistema e recursos processuais", que compreendem documentos produzidos pelas equipes ou pela gestão do sistema de saúde - tais como relatórios, protocolos de atendimento etc. Como exemplo desse tipo de recurso material, os profissionais notaram a necessidade de um prontuário informatizado das famílias, mas não relataram qualquer prática das equipes no sentido de sistematizar as informações por meio de relatórios sobre a população. As equipes limitam-se a registrar as informações dos atendimentos nos prontuários e a preencher as fichas com a quantidade dos atendimentos, que devem ser enviadas à gestão municipal de saúde.

A sistematização das informações constitui uma atividade fundamental, pois proporciona a manutenção e organização das informações nas UBS, podendo ainda auxiliar nos processos de aprendizagem organizacional e gestão do conhecimento, de maneira a orientar o trabalho de caráter preventivo. Assim, por exemplo, o processamento de informações poderia ser adotado pelas equipes como uma forma de amenizar o impacto da rotatividade ${ }^{11}$ de profissionais. Ao tratarem da relação entre recursos tangíveis e intangíveis, Mills, Platts e Bourne (2003) assinalam que para

11 Para esta pesquisa foi adotada a definição de rotatividade de Robbins (2002), segundo a qual rotatividade compreende o montante de profissionais que deixam a organização, por demissão voluntária ou involuntária. 
cumprir sua função um recurso material requer recursos intangíveis, a exemplo dos sistemas de informações que requerem a experiência e conhecimento do operador para serem alimentados.

Em resumo, o QCR permitiu reconhecer as relações estabelecidas entre os diversos recursos. Além disso, esse quadro teve uma função organizativa, uma vez que serviu de base tanto para a coleta quanto para a organização e análise preliminar dos dados.

\section{Concepção e considerações dos profissionais sobre recursos}

Conforme descrito no capítulo anterior, a investigação a respeito da percepção dos trabalhadores sobre os recursos essenciais para a ESF foi realizada, em primeiro momento, de forma indireta, por meio da questão "o que é necessário para o trabalho de vocês surtir o efeito desejado?" Ao comentarem esta questão, os profissionais fizeram referência, principalmente, a recursos não materiais:

\footnotetext{
"Daí que vem a importância da confiança, do bom relacionamento com o paciente, porque se ele está fazendo algo errado... com a confiança que você tem nele, você pode dar um puxão de orelha. Se não tem esse laço, você vai chegar a pessoa vai dizer 'não, não vou fazer isso', e a gente fica meio travado, não vai falar o que é correto." ACS 1

"Ele vem em busca, na verdade, do atendimento médico, mas às vezes ele tendo uma orientação, que ele vai escutar, absorver e fazer, vai resolver o problema dele!" ENF 2

"A gente está [neste serviço] porque a gente sente prazer em falar, porque às vezes a gente vai na casa das pessoas, não precisa nem você levar nada, falar nada, basta você ficar ali uns 15 minutos escutando o que ela tem para falar." ACS 1
}

Como forma de atender as necessidades dos usuários, os profissionais destacaram a importância do trabalho de orientação (atividade essencialmente relacional) e notaram a relevância de recursos não materiais (confiança e escuta) para o êxito desse trabalho. Nota-se a pertinência atribuída à não materialidade dos recursos utilizados quando, por exemplo, uma das profissionais diz que "não precisa nem você levar nada" para realizar o trabalho. Neste caso, a importância da presença do profissional com capacidade de escuta e relação de confiança desenvolvida, que 
foram apontados como recursos centrais para o atendimento, se confirma pela reincidência de relatos sobre a carência de profissionais.

\begin{abstract}
"A gente não tem funcionário, não tem auxiliar, tem dois para cada equipe, se um pegar atestado já desfalca a equipe inteira porque fica todo mundo perdido." ENF 4

"Outro recurso também seria quantidade... quantidade de funcionários, o problema é que nesta UBS falta muita, muita gente." MED 4

"A gente está com três cardiologistas de referência para o município inteiro! Por mais que o doutor [médico da ESF] peça como urgência, tem uma fila de espera de urgência. Então, a falta de recurso humano... A gente está sem referência em pediatria, a gente está sem referência em psiquiatria." ENF 5
\end{abstract}

Nos depoimentos sobre o recurso "profissionais", os trabalhadores relataram carência desse recurso em todas as categorias que compõem as equipes de saúde da família: médico, enfermeiro, ACS, auxiliar de enfermagem e auxiliar administrativo ${ }^{12}$. Além disso, os trabalhadores apontaram a insuficiência em algumas especialidades médicas (pediatria, cardiologia e psiquiatria), nos outros serviços que compõem a rede de saúde de referência. Como consequência dessa carência de profissionais, as equipes relataram sofrer com a sobrecarga de trabalho.

\footnotetext{
"Aí você começa a receber puxão de orelha. Tem pouco funcionário, uma faltou, outra está de atestado... já não é mais [trabalho] por equipe. Mas ela precisa fazer 2 grupos por mês e fazer 40 visitas lá fora." ACS 4

"É falta de profissional... às vezes faltam médicos, não é?! Tem que ter mais médicos para atender. Tem que ter, porque um médico só para atender 5.000 pessoas em uma comunidade." ACS 2

"Por conta dessa demanda que a gente tem, às vezes, até para fazer a supervisão das ACS é difícil, entendeu? Seria uma função da enfermeira, não é? A gente tem que direcionar os nossos funcionários, só que para isso eu tenho que ter tempo." ENF 2
}

Foi notada uma tendência das equipes de concentrarem-se sobre as atividades que exigem uma resposta de curto prazo - como realizar o trabalho burocrático e responder à demanda espontânea - deixando de realizar aquelas que são estratégicas para o modelo, pois necessitam de maior tempo para planejamento e execução.

\footnotetext{
12 No município todas as equipes de saúde da família contam com o cargo de auxiliar administrativo. Este profissional é responsável, essencialmente, por organizar a agenda de atendimento dos médicos e enfermeiros e de realizar o atendimento aos usuários, na recepção das unidades.
} 
Assim, são deixadas em segundo plano atividades como supervisão dos ACS, grupos de orientação e visitas domiciliares - atividades fundamentais para criação e manutenção da confiança e do vínculo, recursos não materiais essenciais para a produção do cuidado. A declaração abaixo ilustra essa inversão do modelo, que organiza seu atendimento em torno de casos de urgência (problemas agravados), em detrimento da proposta preventiva.

\footnotetext{
"Hoje eu tive um caso assim, paciente acamado que está precisando de visita. Como não tem gente, eu tive que dizer que ela precisa voltar, agendar com a enfermeira e aguardar a visita dela. Então, são problemas que a gente poderia resolver na hora, mas não, tem que agravar, para depois resolver." AUX 1
}

A "solução" implicada no depoimento citado, traz consequências para o modelo, como a perda da confiança do usuário e a baixa resolutividade. Segundo os profissionais, quando as unidades contavam com efetivo maior de funcionários, as atividades eram melhor distribuídas, a documentação das famílias melhor organizada e o tempo de espera dos usuários para retirada de exames e agendamento de consultas era menor. As atividades mencionadas, além de cumprirem papel de manutenção das condições de funcionamento das unidades, são fundamentais para o desenvolvimento da confiança do usuário no serviço e nos profissionais.

Quando indagados diretamente sobre recursos - "O que vem à mente de vocês quando falamos em recursos?" - os profissionais referiram-se somente aos recursos materiais, que podem ser visualizados. Durante a validação da lista de recursos disposta no QCR, a concepção de recurso foi discutida, apresentando-se a noção de recursos imateriais. Os profissionais relataram que não conheciam esta nomenclatura, mas que concordavam que aqueles recursos imateriais (como confiança, escuta etc), que compunham o quadro, eram fundamentais. Todos os recursos presentes no QCR foram validados e outros acrescentados. Os depoentes concentraram-se, de forma geral, no relato da carência de recursos materiais, desde itens básicos, utilizados nas operações cotidianas da UBS, passando por medicamentos, até produtos relativamente mais complexos (como sonar, otoscópio e sistema de informação).

Os recursos imateriais, reconhecidos e validados pelos trabalhadores, relacionaram-se aos aspectos relacionais, às orientações aos usuários e, além disso, os profissionais se reconheceram como recurso importante. Foi possível notar grande 
valorização dos recursos imateriais, indicando que as questões centrais do trabalho giram em torno desses recursos, que pode ser observada nos trechos abaixo.

"Quando você fala de recurso, é o que a gente tem que pensar para melhoria, não é? Recurso sempre ocorre para isso, para melhoria de trabalho, melhoria de convívio social." ACS 1

"Mas nós acabamos sendo recurso para comunidade. O meio que elas têm para chegar até a UBS." (...) "Recurso pode ser em materiais, pode ser em ajuda de custo, pode ser um panfleto, pode ser uma orientação que a gente leva..." ACS 3

"E material é bem menos, não é? Os palpáveis são bem menos, tudo depende de pessoas." ACS 5

O cuidado, finalidade do processo de trabalho em saúde, é viabilizado por meio da produção de relações entre membros das equipes e usuários. As relações são produzidas com base em processos que, por sua vez, implica a presença de recursos materiais. Isto quer dizer que os recursos materiais atuam como um apoio para o uso e desenvolvimento dos recursos não materiais, como indica o depoimento abaixo:

"Esses dias a gente foi ali assistir um vídeo na escola... e eles têm a sala de vídeo, eles têm a sala de informática, é muito fácil você conseguir falar ali, fazer um grupo ali é muito fácil. Aqui na unidade, se você for fazer um grupo...[é difícil porque não tem estrutura]" ACS 3

O depoimento reivindica a presença de recursos materiais para a viabilização de atividades fundamentalmente relacionais, vinculadas à orientação e prevenção. A sala de vídeo e seus componentes são citados como elementos necessários para a efetiva orientação de grupos de usuários.

As declarações a seguir indicam como principal consequência da escassez de recursos materiais os inconvenientes à realização das atividades.

\footnotetext{
"Problema é que a gente está desestimulada, também, não é? Precariedade dos materiais que a gente tem para trabalhar, falta de recursos desestimula, a pessoa já vem trabalhar mal humorada, com má vontade." ACS 2

"Complicado dessa forma, você tentar fazer seu trabalho, mas você não consegue" MED 1
}

Os depoimentos descrevem efeitos da falta de recursos materiais sobre a desmotivação dos trabalhadores. Os aspectos destacados pelos profissionais 
(desmotivação, mal humor, má vontade e frustração) estão relacionados às subjetividades dos trabalhadores e influenciarão, diretamente, no uso e desenvolvimento dos recursos não materiais.

Segundo os profissionais, a presença adequada de recursos materiais no processo de trabalho gera benefícios ao modelo, como: proporcionar melhor distribuição das atividades entre os trabalhadores, minimizar sobrecargas de trabalho e falhas nas operações, reduzir o número de encaminhamentos, incrementar a resolutividade das UBS's e, por fim, potencializar o tempo de resposta das operações. A redução de encaminhamentos e a maior agilidade em processos e operações foram mencionadas como resultado de um maior aparelhamento das unidades, via construção de laboratório próprio e aquisição de sistema de informações.

Como síntese do debate acerca da concepção de recurso dos trabalhadores, pode-se considerar que, conceitualmente, a noção de recursos das equipes liga-se à ideia de recursos materiais. No entanto, percebe-se que o papel destes recursos é de suporte para o uso e desenvolvimento dos recursos não materiais. Além disso, os pontos críticos que devem ser observados para o bom funcionamento das unidades, relacionam-se aos recursos não materiais, particularmente aos recursos humanos e relacionais, considerados pelos profissionais como essenciais para a produção do serviço na ESF.

Nota-se que o desalinhamento entre o que os profissionais reconhecem conceitualmente como recurso (os materiais) e o que eles realmente necessitam e valorizam para a realização de suas atividades (os não materiais), traz dificuldades à produção do cuidado. Enquanto os recursos imateriais não forem, de fato, compreendidos como recursos, haverá um número reduzido de ações voltadas ao seu gerenciamento (uso e desenvolvimento). 


\subsection{Tema 2: Debatendo a importância das relações e os principais recursos das relações}

\section{Vínculo: importância e desafios para seu desenvolvimento}

O vínculo foi descrito pelos trabalhadores como um dos principais recursos não materiais envolvidos no trabalho na ESF. Ele compreende uma diretriz fundamental para a consolidação do modelo da $\mathrm{ESF}^{13}$ e para o fortalecimento da atenção integral em saúde. As diferentes dimensões do vínculo - afetiva, terapêutica e da continuidade (CAMARGO JR. et al., 2008) - foram encontradas nas falas dos profissionais. A dimensão afetiva do vínculo expressou-se no sentido da empatia entre profissional e usuário:

"Tem que dar atenção igual para todos, então o vínculo é isso, você facilitar a aproximação, você tentar criar uma empatia com o paciente." ACS 3

Em sua dimensão terapêutica, ele foi compreendido como um novo aspecto do ato de cuidar, associado à capacidade do profissional dar atenção, estar presente e preocupar-se com o usuário. Ou seja, a possibilidade de desenvolvimento do vínculo mostrou-se atrelada ao engajamento e à responsabilização profissional, dos quais depende a produção eficaz da solução almejada pelo usuário.

\footnotetext{
"A gente constrói o vínculo no todo... o paciente olhando isso, todo mundo junto, ele fala 'realmente, as coisas fluem bem, eu falo pra ACS, ela passa para enfermeira, que passa para o médico'. Então, ele tem mais confiança, sabe que a gente não vai só ouvir e tchau." ACS 1

"A gente precisa mesmo é se preocupar com o nosso paciente, eu acho. Às vezes a gente pensa assim: 'ah, é só mais um paciente', mas eu acho que se a gente não se preocupar com ele, a gente não vai ter vínculo." ACS 7
}

A continuidade do cuidado também foi descrita como uma dimensão importante do vínculo, o qual se relaciona ao conhecimento adquirido pelo profissional sobre o usuário, ao longo de sua experiência no território, e à confiança deste no profissional.

\footnotetext{
${ }^{13}$ Evidenciado durante etapa de pesquisa bibliográfica, realizada nos principais periódicos e bases de dados da área da saúde.
} 
"E vínculo é manter a constância com ele, com as famílias." ACS 2

"Então, vínculo para mim é a confiança que o paciente deposita na gente, eu acho que tem mais a ver mesmo com confiança." ACS 7

Vale destacar a necessidade de que a confiança seja recíproca, não unilateral, pois, do contrário, pode representar a adoção pela equipe de práticas contrárias à proposta de construção de um projeto terapêutico conjunto e que, consequentemente, ferem o princípio de corresponsabilização e entravam o desenvolvimento da autonomia do usuário.

A importância do vínculo para a produção do cuidado deve-se a sua capacidade de promover trocas de conhecimentos entre profissionais e usuários. Este novo conhecimento estabelecido, associação de saber técnico e popular, alimenta a construção de projetos terapêuticos realmente compartilhados e favorece a construção da atenção à saúde (SANTOS et al., 2008). O fragmento a seguir destaca duas consequências positivas do vínculo usuário-profissional para a produção do cuidado.

\footnotetext{
"Mas é o médico que tem que trabalhar isso... é o trabalho do médico, no psicológico da pessoa. A pessoa já é doente, ela quer remédio, mas se você conseguir trabalhar com ele, ele vai desapegar daquilo, é o vínculo que você vai estabelecer com ele, confiança, 'confia em mim, eu sei o que eu estou fazendo. Eu vou tirar esse remédio, se não der certo, você volta e a gente avalia de novo'. Mas tem médico que diz: 'Você quer? Tome!'." ACS 1
}

Primeiro, o desenvolvimento das dimensões ligadas à afetividade e à continuidade do cuidado faz com que o usuário se sinta mais à vontade para relatar para o profissional fatos de sua vida, de sua família ou comunidade - o que compreende um aspecto central para um modelo tecnoassistencial que aborda a saúde segundo suas dimensões biopsicossociais. Segundo, o vínculo foi reconhecido como uma ferramenta para reeditar práticas estabelecidas pelo modelo tradicional de saúde que ainda permanecem presentes, tal como apontado pela ACS, cuja fala ressalta o papel do vínculo e da confiança para a desconstrução da prática da medicalização da saúde. Um último aspecto positivo do vínculo, identificado nas falas dos sujeitos da pesquisa, foi seu impacto na resolutividade do modelo. 
"Definir prioridades, também, quando a gente tem esse elo com os pacientes, conhece todos os pacientes, tem vínculo, a gente sabe a quem dar prioridade, o que é mais urgente." ACS 3

"Porque na primeira visita eu sempre achei todo mundo bem, 'está tudo bem filha, está tudo bem'. Depois de uns três, quatro meses eu vou saber que ela não está bem." ACS 7

A criação de vínculo com os usuários e a continuidade do cuidado proporcionam aos profissionais acesso a informações mais precisas e estas, por conseguinte, auxiliam na definição de prioridades para a ação. Nesse sentido, o segundo depoimento mostrou que o vínculo foi a condição para que o profissional alcançasse o recurso "escuta" e, por esta via, produzisse ações de saúde mais eficazes.

O desenvolvimento do vínculo é considerado de responsabilidade de todos os profissionais que atuam na ESF. No entanto, por sua proximidade com a comunidade - garantida pelas visitas domiciliares programadas - o ACS ${ }^{14}$ é considerado o pilar da criação do vínculo entre usuários e equipe de saúde. Os depoimentos abaixo identificam o protagonismo do ACS em relação ao vínculo, sendo que um deles descreve a mudança na forma de contratação profissional, como forma de evitar a rotatividade ${ }^{15}$ e garantir a criação e manutenção do vínculo.

"Por isso que eu acho que o principal do vínculo, para conseguir o vínculo é a confiança do paciente no agente comunitário." ACS 7

"O objetivo da gente ser da prefeitura era se acabar o contrato com alguma terceirizada a gente continuar, para que o paciente não perca o vínculo que já tem com aquele ACS." ACS 2

Uma das ACS (depoimento abaixo) apontou a necessidade de capacitação profissional como meio de garantir a eficiência do trabalho de orientação e prevenção. Contudo, muitas vezes, essa atividade estratégica para a organização do processo de trabalho encontrava-se em segundo plano, pois - conforme assinalado na discussão do tema 1 - as enfermeiras relataram que, frequentemente, sua rotina de trabalho

\footnotetext{
14 O ACS mora na área de atendimento da UBS e é referência para uma microárea, diferente dos outros profissionais da equipe que são referência para a totalidade da área.

${ }^{15}$ Durante a execução da pesquisa, a rotatividade profissional foi baixa para os ACS, que compõem o quadro de funcionários da administração direta do município.
} 
limitava-se a responder as situações emergenciais, em detrimento de atividades planejadas, como a supervisão do trabalho dos ACS.

"Mas não adianta nada você ter o vínculo e você não saber informar direito o paciente, acho que você tem que ter capacitação também, além do vínculo." ACS 3

No caso, a ACS demanda acesso às tecnologias leve-duras, isto é, aos saberes e técnicas estruturados, reconhecendo que o vínculo constitui uma ferramenta essencial, mas se articulada a outras tecnologias. O profissional de saúde, por atuar em um contexto de alta imprevisibilidade, necessita articular diferentes tecnologias de saúde. No caso da ESF, essa articulação deve ser comandada pelas tecnologias leves, sendo a capacitação compreendida como suporte ao uso e desenvolvimento do vínculo. Contudo, embora o vínculo seja um dos recursos imateriais mais relevantes, os ACS relataram algumas dificuldades vivenciadas por eles a partir do estreitamento do vínculo com a comunidade.

“O vínculo é bom e às vezes não. Às vezes você está aqui no posto e está
saindo já, tem um paciente que vem: 'ah, estou esperando o resultado de um
exame, esperando isso e aquilo. Viu, não dá para você ir lá e pegar e fazer
isso para mim?' Isso não é função minha, tem que esperar a senha e ficar
sentado aqui mesmo, ter paciência, não é? Âs vezes, eles acham que a gente
tem obrigação, então para que serve o agente de saúde, não é? Muitas vezes
você ouve isso, porque já criou vínculo e já dá uma certa liberdade, então tem
que saber ter o vínculo. Evitar e até explicar para eles o que você pode fazer,
qual a sua função.” ACS 2

"É isso, a pessoa achar que a gente é empregada dela, o leva e traz." (...) "A outra dificuldade de ter muito vínculo com o paciente é que ele acha que faz parte até da sua família. Até sábado e domingo quer bater na sua casa. Falar sobre serviço fora do horário, porque você mora na região em que trabalha." ACS 1

As falas referem-se a inconvenientes que se relacionam a dificuldades na gestão dos recursos intangíveis, particularmente relativos ao desenvolvimento da dimensão afetiva do vínculo. Observa-se a falta de limites bem definidos dos lugares ocupados pelo ACS, como trabalhador e como morador. Isso foi evidenciado pelas concepções errôneas por parte da população atendida, com duas consequências marcantes: a invasão da privacidade do ACS morador e a confusão quanto a função do ACS trabalhador. 
Durante a observação de uma reunião de equipe, a partir do relato de uma ACS, pode-se observar a consequência da dimensão afetiva na/para a produção do vínculo. Na ocasião, a ACS comunicou aos colegas de equipe, bastante emocionada, o falecimento de um senhor que residia em seu território. Tratava-se de um usuário que morava somente com sua esposa, com quem era casado há mais de 60 anos. $\mathrm{A}$ ACS os acompanhava, regularmente, por meio de visitas domiciliares. Segundo ela, o casal não tinha nenhuma queixa de saúde, mas sentia, apenas, necessidade de alguém para compartilhar suas histórias. Assim, ela os visitava toda semana, tomava café com o casal e ouvia seus relatos. Dias após o falecimento ela voltou a visitar a casa, mas se mostrou emocionalmente fragilizada pela ausência do usuário e pelo sofrimento da esposa, que agora estava ainda mais só e muito fragilizada.

No caso relatado, destaca-se a importância da visão ampliada do processo de saúde e doença. Um olhar convencional, regido apenas pela visão biológica, desconsideraria qualquer acompanhamento desta família, uma vez que seus membros não apresentavam nenhum problema biológico de saúde. É possível notar que o vínculo desenvolvido favoreceu o acesso às reais necessidades da família, a partir da visão de que a escuta e a atenção compreendem o ato de cuidado.

Com relação às barreiras ao desenvolvimento do vínculo, os profissionais destacaram: rotatividade, aspectos éticos, pressão por cumprir metas de gestão e resolutividade. Quanto à relação entre a rotatividade e a criação e manutenção do vínculo, os depoimentos abaixo são ilustrativos:

\footnotetext{
"Isso tem a ver com a troca de funcionários da empresa. Muitas vezes os funcionários mais antigos tinham vínculos com muitos pacientes. O moço da vacina, está aqui há muitos anos, tem vínculo com os pacientes. Agora, troca os funcionários a cada dois ou três meses. Isto tem a ver com a instabilidade." ACS 2

"De vinculo, não é? Porque a gente tem que levar os auxiliares, certos pacientes têm que ver, não conhecem, não é? Eles não conhecem o paciente." ACS 4
}

A consequente descontinuidade do cuidado, relativa à mudança sucessiva dos profissionais, foi notável nos depoimentos, sendo atribuída à descontinuidade na relação usuário-profissional. Contudo, vale assinalar que a rotatividade implica uma descontinuidade também no nível da organização do processo de trabalho no interior das equipes, tendo efeitos diretos sobre o serviço prestado. 
Outro entrave ao desenvolvimento do vínculo, destacado pelos profissionais foi a ética profissional, conforme ilustram os depoimentos a seguir.

"É imprescindível! Por que como você vai na minha casa e eu vou contar um problema pra você se... sei lá, falta ética, falta vontade... é uma escuta. Como que fica todo o conjunto?" ACS 4

"Acho que o medo também, não é? Você conta uma coisa para você aqui, que vai contar ali." AUX 1

Os profissionais compreendiam como a dimensão ética de seu trabalho não apenas a exigência de sigilo sobre as informações, mas também a disposição para ouvir e cuidar, ou seja, na capacidade de responsabilizarem-se pelas necessidades de saúde dos usuários.

Quanto às consequências da busca de cumprimento das metas de gestão para o vínculo, os profissionais relataram um desvio do trabalho no sentido da produção de ações burocratizadas e índices puramente quantitativos. O cenário descrito mostrou que as equipes se achavam presas à primazia da mecanização de parte de suas ações, em detrimento de uma prática cuidadora nos moldes previstos pela ESF. Uma discussão aprofundada das metas de gestão será apresentada na análise do próximo tema.

Como último aspecto que na visão dos trabalhadores apresenta dificuldades ao desenvolvimento do vínculo, discute-se a seguir as questões relativas à resolutividade do modelo.

\footnotetext{
"Eu tenho gente que tem super vínculo comigo, mas infelizmente tem comigo, dentro da UBS não tem, não é?! Porque chega aqui, vai passar o problema para o médico, o médico encaminha, não tenta resolver coisas que podem ser feitas aqui." ACS 5

"E o vínculo fica mais difícil quando a gente orienta o paciente a procurar e chega aqui ele não tem o que a gente orientou, ele não consegue... Quando ele não consegue o que precisa, já te recebe de uma outra forma. Ai você tem que remar tudo de novo para conseguir o vínculo de novo com esse paciente." ACS 7
}

Este tema também esteve muito presente nas sessões de grupo e nas reuniões das equipes observadas. Na percepção dos trabalhadores, as falhas na capacidade de resolver problemas do modelo e dos próprios profissionais, distanciam os usuários 
das unidades e, dessa forma, dificultam a criação e o desenvolvimento do vínculo. De modo geral os ACS descreveram a perda de confiança do usuário no ACS, na equipe e no modelo de atenção. No depoimento de uma das ACS fica implícita uma crítica à resistência do médico de vincular-se ao usuário, na medida em que ela considera que ele encaminhou um caso que seria de capacidade resolutiva da ESF. No caso específico dos médicos, a alta rotatividade observada também constitui um entrave à criação de vínculo com os usuários.

Um último aspecto abordado, com relação ao recurso imaterial vínculo, são as iniciativas para realizar o grau de seu desenvolvimento. Sabe-se que uma das dificuldades relacionadas a gestão dos recursos imateriais é, precisamente, o controle de seu uso e desenvolvimento. As narrativas, a seguir, possibilitam tratar deste tema.

\footnotetext{
"Mas no papelzinho, por exemplo, nós vimos escrito que o nosso posto de saúde não é o que mais recebe reclamação, nós estamos tendo um bom vínculo com a comunidade." ACS 3

"Não tenho pacientes reclamando do meu trabalho, se não tenho... eu acho que tenho um vínculo legal com eles." ACS 9
}

Observou-se que as únicas ações efetivadas realizadas, na realidade, eram iniciativas de caráter pessoal dos profissionais. Estas iniciativas restringiam-se, como relatado acima, ao acompanhamento das queixas dos usuários, segundo a lógica: se não há reclamações é porque o desenvolvimento do vínculo é satisfatório. A opinião dos usuários constitui um elemento essencial de grande relevância, especialmente para um modelo em que os mesmos assumem papel de coprodutores do cuidado, no entanto, ela não deve ser analisada isoladamente e, tampouco, interpretada de forma literal. Contudo, não foi relatado nenhum processo de avaliação sistematizada com participação do usuário.

\section{Acolhimento: uma ferramenta e uma postura das equipes}

O recurso acolhimento - uma das diretrizes operacionais da Política Nacional de Humanização $(\mathrm{PNH})$ para a humanização da atenção à saúde - foi apresentado pelos trabalhadores como ferramenta utilizada na porta de entrada da unidade, 
compreendendo a realização de determinadas tarefas, com a finalidade de dar encaminhamento às necessidades dos usuários.

"Aproximar, perguntar, questionar o motivo da vinda do usuário" "direcionar ele para a gerente, a farmácia ou o setor de exames." ACS 4;

"Tem que escutar, tem que saber o que você faz." ACS 7;

"Assumir o problema do paciente... e procurar uma solução." ACS 3;

"Não tem que ser só mais um número... é um indivíduo que está precisando ser visto, atendido." ACS 5;

"Não é agendar uma consulta médica para ele, é ouvir cada queixa, saber como ajudar." ENF 1.

Uma parte dos depoimentos mostrou uma concepção de acolhimento mais próxima da ideia de triagem, ou seja, com a focalização sobre a queixa e encaminhamento. Mas em sua maioria, os depoimentos convergem para a ideia de que acolher consiste em - a partir de um "saber fazer" - receber, identificar e dar resposta às necessidades dos usuários que chegam à unidade de saúde. Alguns aspectos mostraram-se implícitos nos depoimentos, tais como: a escuta qualificada vai para além da queixa, buscando trabalhar com as necessidades que incluem os diferentes determinantes de saúde (biopsicossociais); o encaminhamento, segundo as necessidades, não se limita ao atendimento médico. Nesse sentido, o acolhimento foi compreendido também como uma postura ${ }^{16}$ de aproximação e de responsabilização assumida pelos trabalhadores, implicando em um modo de operar os processos de trabalho em saúde que, para acessar as necessidades do usuário, lança mão, de maneira densa, dos componentes relacionais.

Os profissionais das equipes debateram também sobre as dificuldades enfrentadas na realização do acolhimento. A este respeito, destaca-se a declaração abaixo:

\footnotetext{
"A equipe 1 não pode atender a equipe 3; a equipe 3 não pode atender a equipe 2 , porque... Acolhimento, na teoria tem, tem uns que põem na prática sim, tem uns que assumem. 'É isso que precisa ser feito, é isso que eu vou fazer'. Mas é de pessoa, na verdade é a pessoa. Tem gente que não deixa nem você falar, responde logo, 'não é comigo'. Calma, deixa eu falar, nem que você me dê uma direção." ACS 1
}

${ }^{16} \mathrm{O}$ acolhimento enquanto postura encontra-se conceitualmente descrito em documentos orientadores do Ministério da Saúde para reorganização do modelo de saúde. 
Em seu depoimento, a profissional apontou como restrição ao desenvolvimento do recurso acolhimento a dificuldade de alguns profissionais adotarem uma postura de sensibilização e engajamento com os problemas dos usuários. Concebendo acolhimento como processo baseado em relações humanas e sob responsabilidade de todos os trabalhadores e setores das unidades (MATUMOTO, 1998), compreendese que as dificuldades para seu desenvolvimento se relacionam a outras questões presentes no processo de trabalho das equipes. Desse modo, a falta de sensibilidade e engajamento com as necessidades dos usuários pode estar associada ao não desenvolvimento de laços de solidariedade entre os trabalhadores, podendo, ainda, ser consequência da demanda excessiva e da carência de funcionários, conforme depoimento abaixo:

“... se tivesse mais gente para trabalhar e fazer esse acolhimento, acho que fluiria muito melhor, isso porque a gente conseguiria pegar cem por cento da população que passa por aqui... entendeu? Porque muita gente passa e vai embora porquê não consegue falar com a gente." MED 1

Segundo narra a médica, em virtude do número restrito de profissionais, sua equipe de trabalho tem encontrado dificuldade em atender toda a demanda pelo acolhimento. Repensar o número de profissionais pode constituir uma questão importante para redimensionar o processo de trabalho envolvido no acolhimento, que, diferente da triagem, implica em um maior tempo de atendimento. No entanto, satisfazer essa condição não representa garantia de qualidade no acolhimento, pois isso depende, sobretudo, da postura que os profissionais adotarão. Se eles o assumirão como uma simples tarefa a ser cumprida ou como uma ferramenta que mobiliza sobretudo os componentes relacionais.

A baixa resolutividade do trabalho nas UBS também foi apontada como uma das restrições ao desenvolvimento do acolhimento:

"Os bloqueios que os pacientes têm. Têm muitos pacientes que têm bloqueio porque já foi mal atendido, porque não acredita no sistema, por 'n' motivos." ACS 3

O problema da baixa resolutividade das equipes tem evidentemente determinantes diversos, alguns anteriormente discutidos, como a sobrecarga de trabalho e a rotatividade. Outros aspectos importantes identificados foram a baixa 
responsividade da rede de serviços e a fragmentação do processo de trabalho no interior da equipe, resultado do isolamento e da falta de comunicação dos profissionais.

Por fim, no que tange à relação entre acolhimento e vínculo, os grupos discutiram, ainda que de forma sucinta, a importância do acolhimento para o desenvolvimento do vínculo. A declaração, a seguir, retrata um dos momentos em que os dois recursos foram discutidos de forma conjunta.

"Às vezes a gente vai lá, cria aquele vínculo com ele, daí chega na sala do médico, ele não tem um acolhimento...ele vai ter coragem de falar tudo o que falou pra gente?" ACS 10

Observa-se que o ACS compreendia a necessidade dos recursos vínculo e acolhimento coexistirem no processo de produção do cuidado. O desenvolvimento do vínculo não surtirá o efeito desejado sem o incremento do acolhimento, bem como dos demais recursos relacionais (confiança, respeito, solidariedade, etc.). Além disso, o depoimento explicitou a urgência do acolhimento ser tomado como responsabilidade de todos os profissionais das equipes.

Em resumo, foi notada uma grande dificuldade das equipes de fazerem valer na prática uma concepção de acolhimento que no nível teórico mostrou-se bastante desenvolvido e em acordo com aquela apresentada pelo Ministério da Saúde. Por outro lado, foram observados avanços no sentido de uma postura de maior valorização das relações humanas e responsabilização pelas necessidades dos usuários e comunidade.

\section{Confiança: importância e desafios para seu desenvolvimento}

O recurso confiança tem papel de destaque na reorganização do modelo de atenção da ESF. Nas declarações a seguir, os profissionais das equipes destacaram a relevância da confiança e, além disso, apontaram alguns benefícios que ela proporciona. 
"Por isso, se tem a confiança, a gente já fala, tem um vínculo maior." ACS 1

"Não tem como ajudar, não tem como conversar se não tiver confiança." ACS 8

"Ela vai confiar em mim! 'Ah, eu vou voltar para casa porque se a enfermeira está me orientando e ela falou para eu fazer isso, eu vou fazer!'. Ela vai confiar em mim, ela vai voltar para casa sem achar ruim e vai fazer tudo aquilo que eu orientei." ENF 3

Os profissionais salientaram a importância da confiança para o desenvolvimento do vínculo e para o trabalho de prevenção. Conforme já discutido, a confiança interfere no desenvolvimento do vínculo, em suas dimensões afetiva e da continuidade do cuidado. Essas dimensões dependem, diretamente, da criação de relações interpessoais entre profissionais e usuários e estas, por sua vez, são alcançadas por meio do uso e desenvolvimento da confiança. Quanto ao trabalho de prevenção, nota-se que a confiança atua como agente facilitador do diálogo com os usuários, aumentando, consequentemente, as possibilidades das orientações serem adotadas. Na perspectiva apresentada, a promoção da confiança está centrada nas relações interpessoais (o "bom relacionamento"), como ilustra o depoimento abaixo:

"Uma coisa que a população precisa é confiança! Confiança na equipe precisa de bom relacionamento entre os profissionais da saúde e usuários." MED 5

Para que usuários dos serviços de saúde confidenciem informações pessoais aos profissionais e adotem suas orientações, há um grau de confiança que deve ser estabelecido entre eles. Por sua vez, o estabelecimento da confiança depende da existência de um bom relacionamento interpessoal entre os envolvidos no processo de produção do cuidado. Quanto à visão sobre a interação entre as relações interpessoais e o desenvolvimento da confiança, os trabalhadores relataram uma relação não harmoniosa, o que criava predisposição a certos conflitos.

"Essa questão da relação, infelizmente a população não tem aqui essa relação de proximidade, de respeito." (...) "Eu tenho notado aqui, que as pessoas já vêm muito armadas." MED 1

"Tem muito paciente que é assim 'eu falei com a enfermeira, mas eu vim aqui falar com você, você acha melhor eu fazer isso?' Então assim, eles não confiam, porque se confiassem, iam embora para casa confiando que é isso! O mesmo acontece com a médica." ENF 4 
Os depoimentos apontaram problemas para a constituição de laços de confiança no ambiente das UBS, especialmente no que diz respeito à confiança do usuário na equipe. Mas transparecem também problemas no que concerne à confiança dos profissionais no usuário. Em acordo com Valentim e Kruel (2007), considera-se que o desenvolvimento da confiança deve ser recíproco, uma vez que na ESF o usuário é coprodutor do cuidado e, além disso, as informações necessárias para a construção dos diagnósticos e do projeto terapêutico serão fornecidas por eles. Este ponto de vista não esteve presente nas discussões realizadas nos grupos focais, o que pode indicar uma restrição ao pleno desenvolvimento do recurso confiança, uma vez que a falta de reciprocidade dificulta o desenvolvimento de sua dimensão interpessoal.

Os profissionais colocaram em discussão as consequências de problemas de falta de confiança entre os membros da equipe para o desenvolvimento da confiança entre equipe e usuários.

\footnotetext{
"Uma unidade bagunçada, desorganizada, onde tem rixa entre enfermeiras, entre os médicos, onde tem brigas, o paciente nunca vai querer confiar em você!" ENF 3

"Eu acho que equipe é eu confiar na médica e a médica confiar em mim! No que eu estou falando." ENF 2
}

A confiança interna ganha ainda mais expressão quando as equipes são multiprofissionais, como na ESF, pois para o atendimento das necessidades biopsicossociais, que se relacionam a distintas áreas de conhecimento, a comunicação constitui uma das bases para compor um processo de trabalho não fragmentado. Neste caso, a confiança entre os membros da equipe tem alto grau de influência sobre os relacionamentos e, portanto, sobre o próprio trabalho coletivo.

No relato abaixo o ACS descreve a importância de multiplicar a confiança do usuário, até então personificada no ACS, para toda a equipe, que terá que cooperar entre si e manter um relacionamento harmonioso.

"A gente já conquistou o usuário para ele estar aqui, agora a gente precisa de colaboração, de maior harmonia no trabalho com os outros colegas, a gente já fez a nossa parte. "ACS 1 
Embora os profissionais tenham discutido que os resultados do trabalho dependem de um ambiente que proporcione o desenvolvimento no interior das equipes de relações baseadas no respeito e na solidariedade, eles descreveram um ambiente de trabalho marcado por graves problemas de relacionamento, tais como: falta de respeito, de cooperação, de responsabilidade e de confiança.

Em resumo, como fatores que dificultavam o desenvolvimento da confiança dos usuários no serviço ganharam destaque a baixa resolutividade do modelo e as dificuldades de relacionamentos, tanto entre profissionais, quanto entre equipes e usuários.

Quanto às possibilidades de desenvolvimento da confiança entre equipes e usuários, destacou-se o aprimoramento do conhecimento técnico dos profissionais, via cursos de capacitação.

\begin{abstract}
"A gente pegou mais confiança porque a gente teve apoio, curso do Cefor17 de 6 meses, e agora o de álcool e droga, foram 5 encontros. São coisas que vão agregando mais conhecimento e a gente vai tendo mais firmeza, quando o paciente pergunta algo ou a gente fala o que sabe ou a gente fala 'vou buscar informação e trago para você'." ACS 1
\end{abstract}

Os cursos de capacitação - previstos pelo Ministério da Saúde como educação permanente - estão relacionados ao recurso "conhecimento técnico", categorizado no tipo de recurso "humano"18. Os momentos de formação são importantes na medida que permitem aos membros da equipe refletirem sobre sua prática em conjunto e acompanhados por profissionais de fora da equipe. Essa situação tende a garantir uma condição mais igualitária de discussão entre os membros. Além disso, permite aos membros da equipe visualizarem de modo mais claro seu processo de trabalho, as possibilidades e adequações e, logo, aumentarem a confiança em si enquanto equipe.

Como síntese da análise sobre o recurso confiança, percebe-se que os trabalhadores das equipes reconhecem a importância deste recurso para a produção do cuidado e compreendem sua relação com outros recursos não materiais, como

\footnotetext{
17 Centro Formador de Pessoal para a Saúde de São Paulo (Cefor-SP), integra a Secretaria Estadual de Saúde e concentra sua atuação em projetos de ensino em saúde. Objetiva formar trabalhadores da área da saúde para atuar no SUS, com noções de cidadania e espírito crítico.
}

${ }^{18}$ Ver Quadro de Categorização de Recursos, presente na análise do tema 1. 
vínculo e acolhimento. No entanto, nota-se que o processo de trabalho em saúde ainda conta com entraves ao uso e desenvolvimento desse recurso.

Por fim, pode-se dizer que o fato do recurso confiança possuir as dimensões interpessoal e organizacional - cada uma delas alocada em tipos diferentes de recursos no QCR (relações e reputacional) - representa em si um desafio. Pois, ao mesmo tempo que cada uma dessas dimensões possui suas especificidades e dificuldades, que devem ser cuidadas de forma particular, o pleno desenvolvimento da confiança necessita de um olhar que as integre, uma vez que elas são interdependentes.

\subsection{Tema 3: A repercussão de questões organizacionais e de gestão sobre a produção do cuidado}

Este tema é constituído pelas seguintes discussões: trabalho em equipe, relações de poder, comunicação, rotatividade e metas de gestão.

Ao discutirem dificuldades do trabalho em equipe na ESF, os profissionais relataram situações que evidenciam a existência de representações hierárquicas sendo reproduzidas no interior das equipes:

\footnotetext{
“Não tem, assim, 'nós somos uma equipe', 'eu sou a equipe', 'eu decido e vocês vão fazer', não é assim, dar ordem." ACS 1

"Pessoa tem que parar de ser a estrelinha da equipe, 'sem mim nada funciona', 'eu que mando e desmando', não é assim." ACS 1
}

As depoentes fazem alusão ao fato de profissionais da equipe reiterarem relações assimétricas, que limitam a participação do conjunto da equipe nas decisões. Este nível de assimetria constitui um entrave ao desenvolvimento da interação e construção coletiva de consensos, culminando em práticas fragmentadas.

$\mathrm{Na}$ relação entre profissionais, como um reflexo das representações hierárquicas, determinadas profissões são alçadas a posições "superiores" a outras e as especificidades técnicas são convertidas em autoridades técnicas entre os trabalhadores: 
"Eu vejo como médica, eu fico muito triste é.... ao ver que como na nossa frente, como médica, eles têm um comportamento e na frente da minha enfermeira, da minha auxiliar, da minha administrativa eles se portam de outra forma, então as pessoas mudam muito a personalidade." MED 2

Em sua declaração, a médica reconhece o tratamento diferenciado que os médicos recebem dos usuários do serviço, em relação aos demais profissionais das equipes. Embora não seja objetivo desta pesquisa analisar as percepções de usuários, o comportamento relatado suscitou uma suposição: ao serem mais cordiais com os médicos, os usuários não estariam reproduzindo uma condição estabelecida pela própria equipe de trabalho? Nessa perspectiva, a postura adotada pelos usuários seria uma representação da forma como as relações se dão no interior da própria equipe. Esta suposição ganha ainda mais corpo quando a própria médica, ao narrar o caso, deixa implícito em sua fala uma provável reprodução hierárquica, uma vez que ela é a única profissional que faz referências aos membros da equipe de trabalho desta maneira: "minha enfermeira", "minha ACS", "minha administrativa". Assim, embora seu discurso seja de teor igualitário, ao mesmo tempo, retrata a manutenção de representações hierárquicas arraigadas nas práticas das equipes.

A hierarquização no interior das equipes cria, sobretudo, dificuldades a comunicação entre os profissionais, o que constitui impedimento ao compartilhamento de saberes e leva a fragmentação e orientação individualizada das ações:

\footnotetext{
"Você sabe qual é a impressão que eu tenho? Trabalhamos todos na mesma estrutura física, porém somos equipes totalmente diferenciadas, os administrativos é uma equipe, os auxiliares é outra, e a outra equipe são dos enfermeiros com os médicos! Que a gente tem comunicação, porque os demais não têm comunicação, porque com os demais você não tem comunicação." ENF 4
}

A comunicação que ocorre de forma restrita, fragmenta as equipes entre as categorias profissionais que ainda mantém algum grau de comunicação. A composição dessas "equipes totalmente diferenciadas" reflete, mais uma vez, a reprodução de relações hierárquicas, pois respondem a critérios de autoridade técnica entre os profissionais - as equipes mencionadas pela enfermeira seguem a divisão por categorias profissionais e, além do mais, a única considerada como tendo comunicação é a formada por enfermeiros e médicos. 
Por meio da etapa de observação foi possível perceber que a comunicação no interior das equipes tem intuito basicamente de transmissão de informações técnicas, sem que os profissionais se atenham a discussões de suas próprias necessidades ou da população atendida, com raros momentos de reflexões coletivas. Nota-se que predomina a dificuldade de interação e, consequentemente, uma redução da noção de trabalho em equipe. Este contexto organizacional apresenta dificuldades para a produção do cuidado, uma vez que recursos não materiais essenciais à sua produção - vínculo, acolhimento e confiança - necessitam contar, conforme análise do quadro de recursos, com o recurso comunicação como suporte.

A rotatividade é outro fenômeno organizacional que foi apontada pelos profissionais como fonte de impactos negativos sobre o trabalho das equipes. Durante os seis meses da consecução do trabalho de campo foi possível notar que a rotatividade de profissionais nas equipes estudadas foi acentuada. Ao longo deste período, ocorreram 14 substituições de profissionais, sendo 8 na UBS A e 6 na UBS B. Na UBS A, foram substituídos 2 ACS, 1 enfermeira, e 5 médicos $^{19}$. Na UBS $B, 1$ auxiliar de enfermagem, 3 enfermeiras e 2 médicos. Com relação a estes números, destaca-se que a totalidade dos médicos da UBS A foi substituída.

Dentre as causas apontadas pelos profissionais para rotatividade em suas equipes tem-se: decisão da gestão; insatisfação com o trabalho; falta de comprometimento dos profissionais e oferta de novas vagas de empregos no município com melhores salários. A este respeito, destaca-se que no período de realização da pesquisa houve a troca de empresa parceira do município, que atua na gestão e operacionalização das atividades da ESF. A indicação dos trabalhadores "decisão da gestão" refere-se às decisões tomadas pela nova empresa gestora, neste contexto de início de uma nova gestão.

Com relação, especificamente, ao elevado índice de rotatividade observado entre os médicos das UBS estudadas (7 substituições em um período de 6 meses), os trabalhadores relataram como possíveis razões a falta de perfil profissional

\footnotetext{
${ }^{19}$ A UBS A totaliza 5 médicos porque uma de suas equipes, por cobrir uma área geográfica muito extensa e populosa, possui dois médicos. Enfermeiras e médicos são contratados pela empresa parceira, não fazem parte do quadro de provimento efetivo da administração direta do Município.
} 
adequado à ESF e o desconhecimento das condições de trabalho e demanda elevada por atendimento.

Quanto às consequências da rotatividade para as atividades das equipes, os trabalhadores relataram:

\footnotetext{
"E falta também comunicação da equipe. Antes tinha muito, agora, depois que trocou os funcionários, não sei, pode ser porque tem uns novos ou não... pessoas inexperientes." ACS 1

"Você tem que começar todo o trabalho de novo, você tem que explicar tudo, o porquê do avental, não sei o que... Isso e aquilo, até ela pegar o ritmo demora, a gente é o suporte, então a gente pega e orienta." ACS 4
}

Uma das implicações da rotatividade citada pelos profissionais - e presente também nos resultados do estudo de Stancato e Zilli (2010) - foi seu efeito negativo na produtividade das operações, em virtude do retrabalho com os sucessivos treinamentos, necessários à adaptação dos recém contratados. Além disso, a constante substituição de profissionais acarreta a perda de comunicação, criando barreiras às trocas de conhecimento e, consequentemente, à consecução do trabalho em equipe.

As metas de gestão também foram consideradas um aspecto crítico para o desenvolvimento do trabalho, especificamente pelos grupos compostos por ACS e auxiliares de enfermagem. Eles compreendem como meta de gestão os números de atendimentos individuais, grupos de orientação realizados entre profissionais e usuários e visitas domiciliares. A meta de número de visitas domiciliares é explícita para ambas categorias profissionais, sendo prevista 40 visitas/mês para os auxiliares de enfermagem (gestão municipal) e uma cobertura de $100 \%$ das famílias por ACS (média de uma visita/família/mês), segundo preconiza o Ministério da Saúde ${ }^{20}$. Os trabalhadores consideraram que o trabalho na ESF encontra-se demasiadamente centrado sobre metas quantitativas, constituindo um obstáculo para a organização da equipe em torno do cuidado.

\footnotetext{
"Essa questão de meta é encaminhar número e eu acho que a gente não tem que trabalhar com número, não! A gente tem que trabalhar aqui com pessoas e não com número." ACS 7
}

${ }^{20}$ Portaria № 2.488 , de 21 de outubro de 2011. 
"Não tem condições de fazer 20 visitas no dia, eles prezam o bom atendimento, mas eles não veem o tempo que demora para dar essa qualidade no atendimento. Tem paciente que eu atendo em 10 minutos e tem paciente que em 30 minutos." AUX 1

Os profissionais consideram que o cumprimento prioritário de metas quantitativas fere a possibilidade de dedicarem maior atenção as necessidades dos usuários do serviço. Esta consideração vai ao encontro às ideias de Hubault (2001), Abrahão e Sznelwar (2007), segundo as quais atender ao humano, engajando-se com suas necessidades, não se limita às metas numéricas e a simples reprodução de procedimentos. O atendimento necessita centrar-se em aspectos relacionais, superando, desse modo, os indicadores formais de produção, limitados aos elementos quantificáveis.

\footnotetext{
"Para você ter um olhar clínico você precisa entrar, observar, olhar as relações, como estão funcionando, sem perguntar. Enquanto eu estou perguntando o nome dela ali, eu estou observando como está sendo o tratamento da família." ACS 2

"A gente tem que lidar com metas, você chega na casa do paciente, tem que ser cronometrado... só pegar os dados não vai possibilitar eu fazer a ponte entre ele e a UBS." ACS 2
}

Este cenário compromete o desenvolvimento de três dos recursos imateriais identificados no campo de pesquisa como mais relevantes para a produção do cuidado: confiança, vínculo e acolhimento. Para equacionar o desenvolvimento destes recursos, as práticas de atenção devem organizar-se em torno das especificidades locais - conforme notaram os trabalhadores - e envolver maior investimento de tempo nas relações, de maneira a possibilitar engajamento e responsabilização de ambos os envolvidos no processo.

\footnotetext{
"Reavaliar as metas, eles [os gestores] teriam que conhecer a microárea para depois definir as metas pra cada equipe... cada área tem a sua dificuldade particular." ACS 2

"Para mim a coisa fica positiva quando eu consigo dar fluidez naquilo que eu estou fazendo, eu consigo ter autonomia e desenrolo o problema do paciente, aí para mim é positivo." ACS 4
}

As críticas dos trabalhadores sobre as metas quantitativas estabelecidas pela gestão de saúde dizem respeito à falta de um olhar que considere as especificidades 
locais e a realidade de cada equipe - os microprocessos de trabalho das equipes (FRANCO; MERHY, 2006). Nota-se que um ponto central, que se mostrou em jogo na discussão de metas, foi o recurso "autonomia", identificado pelos profissionais como fundamental, uma vez que permite às equipes programar seu trabalho segundo as necessidades que ela observa.

A análise das colocações dos trabalhadores permitiu algumas considerações entre a articulação dos aspectos organizacionais abordados e a produção do cuidado na ESF. Com relação as metas, apontou o contrassenso entre um modelo baseado na criação de vínculo e acolhimento e profissionais cobrados por metas quantitativas, sem tempo de dedicarem atenção ao usuário, sem visão do todo e do longo prazo. Quanto a rotatividade e as relações hierárquicas, dificultam a comunicação entre profissionais e o trabalho em equipe, inibindo o desenvolvimento do vínculo, do acolhimento e da confiança. Em suma, as condições organizacionais observadas remetem a uma presença considerável de aspectos do modelo médico centrado.

\subsection{Tema 4: Concebendo o modelo e o foco de atuação}

No presente tema, foram analisadas as percepções dos trabalhadores a respeito da relevância das práticas de orientação e prevenção para a ESF. Foram apresentadas, ainda, as principais dificuldades e condições necessárias para a efetivação do trabalho de prevenção na prática das equipes.

Ao discutirem a organização do trabalho na ESF a partir da prevenção, os profissionais, via de regra, remeteram-se à contraposição entre as características centrais do modelo tradicional de atenção e da ESF. Assim, surgiram, por exemplo, oposições entre os termos consulta agendada e busca ativa, medicamento e atenção, encaminhamentos e vínculo e, afinal, buscar a cura e aprender a cuidar da própria saúde. Os termos utilizados para caracterizar a prevenção compreenderam, essencialmente, recursos não materiais (atenção, vínculo e capacidade de aprender), o que sugere que, do ponto de vista dos profissionais, a tecnologia leve encontra-se no nível central da produção do cuidado na ESF. 
Os profissionais assinalaram que as ações de prevenção e promoção de saúde compreendiam uma responsabilidade coletiva da equipe e relataram dificuldades para sua efetivação. Encontram-se entre as dificuldades fundamentais descritas pelos profissionais: resistência dos usuários à reorganização do modelo de atenção, formação profissional "clássica" e alta demanda espontânea.

A resistência dos usuários à reorganização do modelo foi bastante discutida como um entrave para a realização do trabalho preventivo, principalmente nos grupos formados por médicos e enfermeiras. Os profissionais tenderam ao consenso de conceber que o usuário valoriza o modelo médico-centrado e o cuidado curativo e, além disso, que isso constituiria uma barreira ao desenvolvimento de seu papel como coprodutor do cuidado. São falas representativas da discussão:

\footnotetext{
"Se você chamar para prevenção, o posto fica vazio. Se você falar que hoje o posto vai abrir só para prevenção, não vem ninguém." ENF 3

"Ele [usuário] não pensa que tem que prevenir para não precisar passar no médico. Pensa que o médico é a salvação dele, não acha que a própria postura pode evitar a doença." ACS 3

"Eles querem vir aqui e fazer tudo na hora, então é cultural, o povo adora um pronto atendimento." ENF 2
}

Quanto aos limites que a formação clássica impõe ao desenvolvimento do trabalho centralizado na prevenção, o depoimento a seguir constitui um exemplo entre muitos outros que surgiram nos grupos.

"Não, na verdade eu acho que os médicos brasileiros não se formam para trabalhar em UBS, em prevenção, eles se formam para trabalhar em pronto socorro, em clínicas particulares." ACS 7

No cenário descrito pelos profissionais, a reorganização do modelo tecnoassistencial esbarra em profissionais que ainda estão sendo formados nos moldes de atendimento do modelo tradicional. Isto é, profissionais com formação pautada na extrema especialização, na atuação individualizada e na produção de procedimentos e, portanto, centrada no uso e valorização das tecnologias duras. Em estudo sobre competência gerencial dos enfermeiros de saúde da família, Kawata et al. (2011) identificaram aspectos similares: profissionais centrados no cuidado individual e raramente voltados a ações sistematizadas e contínuas. 
Por último, no que tange aos desafios que a alta demanda impõe a consecução do trabalho preventivo, os profissionais assinalaram:

"Nossa dificuldade é isso, a gente está correndo contra o tempo, a população é grande, a gente não consegue, muitas vezes, fazer a prevenção, a gente está fazendo o curativo, curativo, curativo..." ENF 2

"Nós [auxiliares] temos coisas para fazer na rua, só que nós não conseguimos sair, aí o que acontece..." AUX 1

Algumas equipes trabalhavam com um número de usuários superior ao recomendado pelo Ministério da Saúde ${ }^{21}$. Além disso, os dados sugerem que a alta demanda relacionava-se também com o perfil dos territórios abrangidos pelas unidades. Os profissionais mencionaram que, em função dessa alta demanda, as atividades de caráter preventivo têm sua execução, muitas vezes, impossibilitada.

Esse gargalo da produção do cuidado, apontado na literatura (FEUERWERKER, 2014), mostra que enquanto porta de entrada do sistema, as equipes de saúde da família ficam sob estado de tensão ao se depararem com um volume de demanda espontânea que excede as prioridades do serviço, segundo as quais a oferta de ações foi planejada. Esta realidade expõe trabalhadores e usuários a situações conflitantes, criando uma conjuntura desfavorável ao uso dos recursos relacionais, cujo desenvolvimento depende de um contexto de harmonia, respeito e confiança entre os envolvidos na produção do cuidado.

Em síntese, conclui-se que apesar da importância dos recursos imateriais para a efetivação de ações preventivas ser marcante na fala dos profissionais, a problematização dos aspectos do trabalho relacionados ao uso e desenvolvimento destes recursos encontravam-se ainda em um lugar secundário. Ou seja, as dificuldades para a efetivação dessas ações eram discutidas mais em termos de redução da demanda, do que de aspectos relacionados aos recursos não materiais, como, por exemplo, formação profissional, possibilidades para maior desenvolvimento da confiança, ferramentas para desenvolvimento do vínculo etc.

A valorização do trabalho de orientação e prevenção pelos profissionais indica um fortalecimento do processo de ruptura com o modelo médico hegemônico.

${ }^{21}$ O Ministério da Saúde preconiza, segundo a Portaria 2.488, número máximo de 4.000 habitantes por equipe de ESF e recomenda número médio de 3.000 . 
Contudo, alguns questionamentos importantes, não identificados nas falas dos profissionais, devem ser realizados: quais as consequências que as falhas ou não realização do trabalho de orientação e prevenção podem acarretar para a demanda? Os limites relativos à formação profissional podem constituir um entrave para que o usuário veja o serviço de maneira preventiva? A resistência do usuário à reorganização do modelo pode ser índice importante de discussão para repensar o atendimento e, em nível global, os limites do próprio modelo?

\subsection{Tema 5: Conhecimentos, habilidades e atitudes importantes para os trabalhadores da saúde}

No presente tema foram abordadas as discussões acerca dos conhecimentos, habilidades e atitudes que, na opinião dos trabalhadores, são essenciais ao perfil do profissional da ESF. Os recursos que receberam maior atenção na análise deste tema foram os recursos imateriais comprometimento, experiência e competência, uma vez que surgiram de forma mais marcante nos grupos.

$\mathrm{Na}$ declaração a seguir, pode-se observar a visão da enfermeira de uma das equipes sobre a importância do comprometimento para o perfil do profissional.

\footnotetext{
"Aqui a população é grande, são poucos funcionários e perdemos o controle de todo o sistema, que poderia dar muito certo, se tivesse funcionários comprometidos com a saúde da população. Em resolver o problema do paciente e deixá-lo saudável, sem ele necessitar voltar." ENF 2
}

Comprometimento foi compreendido como capacidade de envolvimento com as necessidades dos usuários. Na visão da profissional, o comprometimento pode amenizar os problemas causados pela alta demanda e a carência de funcionários. Ou seja, ela estabeleceu uma relação direta entre comprometimento e resolutividade do modelo. Profissionais comprometidos são mais eficazes em atender as necessidades dos usuários que, dessa forma, não necessitam acessar o serviço diversas vezes para resolver 0 mesmo problema. $O$ depoimento abaixo também se refere ao comprometimento, mas com uma perspectiva distinta. 
"É assim, na área da saúde a gente lida com vida, não é como na parte administrativa, que se a gente rasurar o papel a gente consegue pegar outro na gaveta. A pessoa que gosta do que faz busca dar o melhor para o paciente e é isso que eu vejo que falta aqui nos nossos recursos humanos." ENF 3

Percebe-se uma perspectiva de maior valorização dos aspectos subjetivos do comprometimento, que foi compreendido como "dar o melhor" para o usuário. $\mathrm{O}$ profissional comprometido é aquele que está satisfeito com a profissão e que se vincula ao usuário. Do seu ponto de vista, há um elo entre satisfação com o trabalho, vínculo e comprometimento.

Identifica-se, por fim, um cenário preocupante a respeito do recurso comprometimento, pois os profissionais o reivindicam, reconhecem seu valor e potencialidades, mas, no entanto, denunciam sua carência no processo de trabalho das equipes. A mesma preocupação aplica-se ao debate sobre o recurso experiência:

"É tudo gente mais nova, atrapalha um pouco, também, pela falta de experiência." MED 1

"Contratam sem experiência, daí chega aqui a gente tem que treinar e acaba emperrando um pouco o trabalho, porque a gente não consegue enviar o funcionário para a rua. Eu estou com uma funcionária aqui que está de atestado, a outra não tem experiência para fazer coleta. Eu estou com um monte de coleta e as auxiliares paradas, entendeu?" ENF 2

Os depoimentos relataram a falta de experiência dos profissionais recém contratados, que compõem as equipes. A segunda declaração referiu-se, especificamente, ao caso das auxiliares de enfermagem. As declarações permitem a visualizar a complexidade e os impactos das ações de gestão em saúde sobre as atividades das unidades de saúde. Decisões tomadas quanto à forma de contratação e remuneração dos profissionais, por exemplo, trazem consequências para o desenvolvimento de recursos não materiais essenciais para a produção do cuidado como, no caso, a experiência. Além disso, conforme apontado na análise do QCR, o recurso experiência oferece suporte ao desenvolvimento do recurso confiança. Assim, a ausência da experiência no processo de trabalho das equipes não traz impactos somente às atividades operacionais, como observado pela enfermeira, mas também ao desenvolvimento de recursos essenciais aos objetivos da ESF. Deste modo, 
salienta-se a necessidade dos gestores da saúde também considerarem em suas decisões os recursos não materiais, suas interconexões e especificidades.

Como recurso imaterial, a competência pertence ao campo das tecnologias leve-duras. Como todo recurso que compõe este campo tecnológico, é constituída, ao mesmo tempo, pelos lados leve e duro. Dependendo das circunstâncias e das características do processo de trabalho, haverá a imposição de um desses lados em relação ao outro. A colocação abaixo se refere a este debate:

\begin{abstract}
"Porque não adianta contratar um monte de gente que não tem competência para exercer a função, seja ACS, enfermeiro, auxiliar ou médico. Cada um tem que estar disposto a fazer a sua parte." ACS 8
\end{abstract}

Na concepção que atravessa a colocação acima, competência foi tomada como conjunto de capacidades técnicas necessárias ao exercício de determinada função, incorrendo, dessa forma, em um problema apontado na revisão bibliográfica, de limitar competência aos conhecimentos relacionados a realização da tarefa. Enquanto que nas falas seguintes percebe-se a valorização do componente leve da competência.

\footnotetext{
"Competência é eles terem o olhar humanizado para o problema do paciente. Ele não precisa saber mais que todos os médicos da cidade, não é isso. Ele ter um olhar humanizado." ACS 3

"Então, assim, o problema não é saber, o problema é buscar o conhecimento." ENF 4

"Acho que para trabalhar aqui vai além da parte técnica, vai muito da pessoa, do perfil, tem que ser comprometido, saber trabalhar em equipe, ter responsabilidade, saber que a vida do paciente está na nossa mão, que eu não trabalho sozinho, sem o médico eu não faço nada, sem auxiliar, sem ACS, a gente não é nada, vai muito além só da parte técnica." ENF 2
}

O que está em questão na perspectiva de competência identificada nesses últimos depoimentos é a capacidade de colocar o conhecimento em prática, no ato vivo de cuidar. Neste sentido, o conhecimento profissional estruturado deve estar conjugado aos recursos da tecnologia leve, tais como: comprometimento, capacidade de trabalhar em equipe, responsabilidade e olhar humanizado.

Finalmente, embora a importância destes recursos seja reconhecida, seu desenvolvimento representa grandes desafios, sendo os recursos humanos uma 
questão central, tanto no que tange à formação e ao perfil dos profissionais - ainda distantes do idealizado - quanto a sua contratação e manutenção nas equipes.

\subsection{Síntese da análise temática}

Quanto às dificuldades da organização do trabalho:

A composição básica das equipes mostra-se insuficiente para a proposta de atendimento biopsicossocial, pois as mesmas são formadas essencialmente por profissionais cujos centro de cuidado relacionam-se ao determinante biológico da saúde. Neste sentido, o NASF (Núcleo de Apoio à Saúde da Família), foi concebido pelo Ministério da Saúde como unidade complementar ao trabalho das equipes de saúde da família, sendo composto por profissionais de formações diversas, segundo a necessidade identificada no território. Assim, no caso estudado, em que foram relatadas dificuldades para atender as necessidades relacionadas a problemas psicológicos, a construção de um NASF com profissionais da área de saúde mental pode compreender uma alternativa interessante. Este e outros problemas de acesso a determinados profissionais e serviços, causados, evidentemente, por limites na capacidade da rede de serviços, relacionam-se também ao fluxo de informações entre os diferentes níveis do sistema.

Outra questão observada sobre a composição da equipe foi a insuficiência de profissionais com o perfil adaptado ao trabalho preventivo. O perfil profissional compreende um problema enfrentado pela ESF em nível nacional, pois as condições vigentes da implementação da atual proposta de trabalho guardam as marcas do modelo biomédico, desde a primazia da formação centrada na clínica individualizante e a valorização diferenciada das profissões até a produção de índices de produtividade que não se adaptam aos serviços.

As metas e índices utilizados pelas equipes são excessivamente centradas em indicadores quantitativos que visam atender aos compromissos da coordenação municipal com o Ministério da Saúde. Estes dados cumprem papel organizativo importante para o planejamento de ações no nível central do sistema, mas perdem significância no cotidiano das equipes, pois desconsideram as especificidades locais e as reais necessidades da população. Dessa forma, por exemplo, os dados agregados de uma região informando o número de internações a partir da implantação 
da ESF mostra-se relevante para orientar as ações do governo federal. Enquanto que o dado isolado de internação (ex: de três para uma internação) inserido no SIAB pela equipe de saúde da família mostra-se sem relevância para a organização de seu trabalho. Em estudo realizado junto à ESF, Silva e Trad (2005) notaram que nem sempre o valor das informações geradas pela equipe é incorporado à sua prática de trabalho. Além disso, conforme assinala Mascia (2007), os resultados originários do nível operacional e expressos por instrumentos de gestão são sínteses, passíveis de imperfeição, pois, de maneira geral, os valores veiculados apresentam atividades realizadas, mas não as ações nelas envolvidas. Dessa forma, o nível de estabilidade, característico desses indicadores, não corresponde à dinâmica dos fatos que eles restituem.

As equipes careciam de instrumentos qualitativos de avaliação, capazes de ter significância prática para o planejamento e reorientação de seu processo de trabalho, possibilitando uma maior visibilidade aos resultados obtidos e, consequentemente, desenvolver a confiança das equipes. Em concordância com o encontrado por Silva, Lancman e Alonso (2009), foi observado que as equipes utilizavam como instrumento de avaliação do serviço, quase que exclusivamente, os registros das consultas efetuadas.

A equipe precisa exercer sua autonomia no sentido da avaliação do próprio trabalho, pois, conforme anteriormente discutido, a essência do trabalho é a qualidade da solução particular apresentada ao usuário. Para que isso ocorra o profissional deve aprimorar a capacidade de escuta e compreensão das necessidades do usuário, sendo indispensável despender tempo no diálogo com o mesmo.

Quanto às dificuldades relacionadas às condições de trabalho:

Observou-se que a rotatividade ocorreu principalmente entre profissionais contratados pela empresa parceira (médicos, enfermeiros e auxiliares de enfermagem) e não entre os ACS, contratados diretamente pelo município. Como consequência da rotatividade, observou-se no interior das equipes: retrabalho com treinamento dos profissionais recém contratados, perda de comunicação, descontinuidade das ações e alta demanda decorrente de períodos de carência de profissionais. Neste caso, o médico de uma equipe, por exemplo, era responsável pela cobertura de duas ou mais equipes ao mesmo tempo, e assim conseguia atender apenas os casos mais urgentes, o que inviabilizava a continuidade do trabalho 
preventivo em sua equipe. Além disso, a rotatividade profissional prejudica o desenvolvimento da confiança e do vínculo no interior da equipe e dela com a população, como encontrado no estudo de Marqui et al. (2010).

Em algumas equipes, a sobrecarga de atendimento relacionou-se ao fato do número coberto de famílias ser maior que o previsto pelo Ministério da Saúde, mostrando-se também ligada às falhas de resolutividade. Estas falhas levavam o usuário a retornar à unidade com o mesmo problema ou com o problema agravado, o que reforçava seu comportamento de buscar a unidade em caso de necessidade imediata. Quando o caso era mais leve ou não envolvia uma necessidade biológica o usuário acabava não sendo atendido, gerando desconfiança e insatisfação com o trabalho da equipe. Assim, a resistência de uma parte dos usuários ao modelo, identificada pelos profissionais como uma causa da sobrecarga de trabalho, é também um de seus efeitos. Percebe-se que o processo de trabalho das equipes girava em torno de problemas imediatos e tipicamente biológicos, implicando em problemas na execução de atividades centrais, como de orientação e prevenção.

A confiança do usuário no modelo da ESF depende das implicações do trabalho preventivo nas suas "condições de existência" (ZARIFIAN, 2008). Como nota Alves (2005), é a disseminação do conhecimento acadêmico, intermediada pela ação dos profissionais de saúde, que ao alcançar o cotidiano dos usuários permite que o mesmo melhor compreenda o processo saúde-doença e adote novos hábitos e condutas de saúde.

A manutenção de práticas de cuidado fragmentadas segundo a categoria profissional e organizadas de modo burocratizado e hierarquizado (CAMURI; DIMENSTEIN, 2010) revelou profissionais presos a atividades compartimentadas. Ou seja, alheios ao todo do processo de cuidado e ao resultado final pretendido. Assim, por exemplo, se, em determinado processo de cuidado, o profissional reconhece que sua responsabilidade limita-se a vacinar, reconhecerá como resultado de seu trabalho o total de pessoas vacinadas. Ele deve ter dimensão do todo do processo de trabalho e ser capaz de ajudar a pensá-lo, responsabilizando-se pelo resultado coletivo do mesmo (transformação nas condições de vida do usuário), uma vez que seu trabalho visto isoladamente não implica em mudança significativa. Ao mesmo tempo, conhecer todo o processo permite que o profissional identifique sua tarefa (vacina - 
quantificável) como parte de uma cadeia, dependente de outras ações, como, por exemplo, da orientação (não quantificável) que a antecedeu, dada pelo ACS.

Para fazer face ao entrave no compartilhamento de saberes, os espaços coletivos de planejamento, construção e avaliação das ações precisam ser potencializados. Na prática, as reuniões de equipe mostravam-se presas à socialização de planejamentos individuais dos profissionais de nível superior (SILVA; TRAD, 2005) e à resolução de aspectos burocráticos (COLAMEO et al., 2007) e quantitativos do trabalho (ex: informes da gestão, documentos a preencher, determinação das visitas e dos grupos programados), sendo raramente voltadas à discussão de aspectos qualitativos concernentes ao cuidado em si, como o compartilhamento de informações dos usuários, supervisão técnica dos ACS, planejamento de "como fazer", papel dos envolvidos etc.

Questão relevante para a desconstrução das práticas fragmentadas e a desburocratização dos espaços coletivos de reflexão é o desenvolvimento de uma comunicação autêntica. Para que a comunicação passe da esfera individual (por exemplo de um ACS) à coletiva, tornando-se recurso "informacional" para toda a equipe, ela necessita de espaços de debate coletivo, para que o profissional que é fonte da informação possa partilhá-la com os demais profissionais.

De modo geral, a comunicação ocorre nos corredores das unidades de saúde para dar respostas as situações imediatas vivenciadas no cotidiano do trabalho. Ou seja, embora ela tenha sido reconhecida como um recurso fundamental, carece de um investimento das equipes em seu desenvolvimento. O mesmo problema foi observado com relação a diversos recursos imateriais, que por seu grau de intangibilidade não são facilmente administráveis, pois se desenvolvem no trabalho vivo em ato (MERHY, 2007), na prática e na experiência (HUBAULT, 2001) e a partir de eventos (ZARIFIAN, 2008).

Uma situação ou um evento resolvido por dois no corredor pode alimentar a discussão nos espaços coletivos. Neste caso, a situação discutida gera conhecimento para o coletivo da equipe, pois as informações trazidas constituem-se em recursos para futuras tomadas de decisão. Ou seja, a comunicação mostra-se um recurso fundamental para o desenvolvimento da aprendizagem organizacional. Zarifian (2008) nota que é quando nos mobilizamos em torno de um evento que as ocasiões e as necessidades de comunicação são mais acentuadas. Além disso, as informações 
dispersas (recursos intangíveis) entre profissionais precisam, em certa medida, serem sistematizadas na forma de documentos orientadores (recursos tangíveis) que possam ser retomados para reorientação do processo de trabalho e planejamento das ações preventivas, a médio e longo prazo. Ou seja, um recurso intangível sistematizado dá origem a um tangível, que, por sua vez, poderá ser retomado para desenvolvimento de outros intangíveis (como vínculo, acolhimento, escuta) - ainda que eles não sejam facilmente, nem totalmente, sistematizáveis.

Em um contexto de constantes substituições de profissionais, com consequente retrabalho e comunicação restrita, as equipes enfrentavam dificuldades para sistematizar conhecimentos e planejar suas ações. Sem saber se contariam, no curto prazo, com determinado membro, as equipes viam inviabilizadas as atividades de planejamento restando trabalhar com aquelas relacionadas à demanda espontânea. Dessa forma, tem sua autonomia afetada com relação ao planejamento e execução de simples atividades.

Além disso, os impactos negativos da rotatividade eram sentidos sobre a produção do vínculo e da confiança entre equipe e usuário, interferindo, consequentemente, para a mecanização de ações que deveriam ser mais humanas como o acolhimento, que acabava mantendo as marcas características da antiga triagem. 


\section{CONSIDERAÇÕES FINAIS}

O processo de trabalho mostrou-se, na prática, centrado na reprodução de procedimentos, mesmo que os profissionais tenham apresentado uma concepção de saúde marcadamente centrada na produção de relações. As práticas que expressavam o modelo idealizado pela ESF mostraram-se submetidas à uma rotina de trabalho e uma forma de avaliação fundamentalmente baseada no modelo médicocentrado. De modo geral, os diferentes aspectos do processo de trabalho encontravam-se centrados na mensuração, no biológico e nos procedimentos, enquanto que os pontos críticos para sua execução compreenderam, no geral, aspectos imateriais. Como consequência, muitas vezes, prevaleceu o emergencial no lugar do preventivo, a medicalização no lugar da escuta, o encaminhamento no lugar da orientação/do cuidado.

Uma contradição essencial pode ser observada na implementação da ESF: entre a ênfase conceitual na produção de vínculo e a produção de metas baseadas, quase exclusivamente, em parâmetros quantitativos. Estes parâmetros devem ser considerados no planejamento e avaliação do cuidado, mas são os parâmetros qualitativos e analíticos que melhor se adaptam ao produto que se espera da ESF. São estes elementos qualitativos da avaliação que podem ser incorporados à prática das equipes, de maneira a reorientar efetivamente as ações de cuidado no sentido das necessidades da população.

Como pontos críticos do modelo da ESF a serem enfrentados foram identificadas as metas excessivamente quantitativas, a alta rotatividade e a baixa resolutividade. Enquanto que o vínculo, a confiança e o acolhimento foram identificados como pontos críticos a serem desenvolvidos e vigiados.

Há um longo processo de construção teórico e prática para a gestão, uso e desenvolvimento dos recursos imateriais, especialmente aqueles relacionados à tecnologia leve. Um conjunto de ações é necessário para que o que concebido no nível conceitual, nos documentos orientadores do Ministério da Saúde e na literatura, efetive-se na realidade prática das equipes. No caso estudado, as mudanças devem incluir ações no nível da gestão como: repensar a forma de seleção e contratação profissional, para dar conta dos problemas relativos ao perfil e a rotatividade 
profissional; incrementar a rede de apoio a ESF, para ampliar sua capacidade resolutiva; repensar metas e construir instrumentos qualitativos de avaliação locais, adaptados aos recursos imateriais relativos à tecnologia leve; priorizar os recursos imateriais na definição de ações gerenciais.

De maneira geral, as ações de gestão devem caminhar no sentido de romper a cisão entre teoria e prática, pois apesar das capacitações oferecidas pela gestão municipal terem garantido aos profissionais uma base conceitual sólida do modelo (com o reconhecimento da importância de recursos como vínculo e confiança), as práticas encontram-se limitadas pelas mudanças ainda reduzidas na organização do processo de trabalho. E assim, vistas globalmente, as práticas ainda não refletem, na mesma medida, os avanços conceituais.

No nível das equipes, as mudanças devem englobar ações como: organizar a supervisão contínua e efetiva do trabalho dos ACS; potencializar a capacidade das reuniões de equipe de discutirem as tecnologias leve-duras e leves, saindo do enfoque informativo e burocrático, para uma postura analítica e de diálogo; construir uma postura proativa para realização de atividades que se encontram no campo de sua autonomia, tais como produção de relatórios e realização de grupos; criar formas de avaliação aplicadas a sua realidade, coesas às necessidades e com a participação do usuário. Neste ponto, vale assinalar que apesar da lógica de serviços ser centrada usuário e tomá-lo como coprodutor do cuidado, o planejamento e avaliação das ações raramente contam com sua participação.

Com a ampliação da concepção de saúde para além dos aspectos biológicos, nota-se entre os profissionais uma maior valorização dos aspectos relacionais, com a consideração das necessidades percebidas, incluindo emocionais e sociais. As equipes percebem seus próprios limites para atender as necessidades da população, adotando uma postura crítica com relação ao seu próprio processo de trabalho, que se concentra sobre as necessidades imediatas, sem dar conta das atividades preventivas e estratégicas para a ESF. Para que as ações deixem de ser isoladas e produzam efeitos globais, as equipes não devem só valorizar os recursos, mas sim pensar estrategicamente formas de desenvolvê-los. 


\section{REFERÊNCIAS BIBLIOGRÁFICAS}

ABRAHÃO, J. I.; SZNELWAR, L. I. In: VIANA, A. L. A. (Coord.). Conclusão Geral - A produção e o trabalho no PSF: uma realidade a ser entendida e disseminada? Inquérito com usuários e profissionais, percepção dos gestores e estudos sobre - trabalho no PSF. São Paulo: Centro de Estudos de Cultura Contemporânea; Consórcio Medicina USP, v. 3, pp. 229-236, 2007.

ALMEIDA FILHO, N. O que é saúde. Rio de Janeiro: Editora Fiocruz, 2011.

ALMEIDA, M. C. P; MISHIMA, S. M. O desafio do trabalho em equipe na atenção à Saúde da Família: construindo "novas autonomias" no trabalho, Interface Comunicação, Saúde, Educação, vol. 5, n. 9, pp. 150-153, 2001.

ALVES, V. S. A health education model for the Family Health Program: towards comprehensive health care and model reorientation, Interface - Comunic., Saúde, Educ., v.9, n.16, p.39-52, set. 2004/fev. 2005.

BANCHS, M. A. Representaciones sociales en proceso: su análisis a través de grupos focales. In: MOREIRA, A. S. P; CAMARGO, B. V; JESUÍNO J. C; NÓBREGA, S. M. (Organizadores). Perspectivas teórico-metodológicas em representações sociais. João Pessoa: UFPB, Editora Universitária, 2005. p.401-23.

BARNEY, J. B. Firm resources and sustained competitive advantage. Journal of Management, v. 7, n. 1, p. 99-120, 1991.

BERTO, R. M. V. S.; NAKANO, D. N. A produção científica nos anais do encontro nacional de engenharia de produção: um levantamento de métodos e tipos de pesquisa. Produção, v. 9, n. 2, p. 65-76, 2000.

BITENCOURT, C. C. A gestão de competências gerenciais - a contribuição da aprendizagem organizacional. Universidade Federal do Rio Grande do Sul, tese de doutorado, 2001.

BOWEN, J.; FORD, R. C. Managing service organizations: does having a "thing" make a difference? Journal of Management, v. 28, n.3, pp. 447-469, 2002.

BRASIL. Ministério da Saúde. Lei 8.080, 1990.

. Ministério da Saúde. Secretaria de Assistência à Saúde. Saúde da família: uma estratégia para a reorganização do modelo assistencial. Brasília, 1997.

. Ministério da Saúde. Programas e projetos: Saúde da Família. Brasília, 1998.

Ministério da Saúde. Secretaria de Políticas de Saúde. Departamento de Atenção Básica. Avaliação da implementação do Programa Saúde da Família em dez grandes centros urbanos - síntese dos principais resultados. Brasília, Ministério da Saúde, 2002.

$2006 a$.

. Ministério da Saúde. Guia Prático do Programa da Saúde da Família,

Ministério da Saúde. Saúde da Família no Brasil: uma análise de indicadores selecionados, 2006b. 
. Ministério da Saúde. O trabalho do Agente Comunitário de Saúde. Brasília: Ministério da Saúde, 2009a. (Série F. Comunicação e Educação em Saúde).

Ministério da Saúde. Avaliação de Tecnologias em Saúde: ferramentas para a Gestão do SUS. Secretaria-Executiva Área de Economia da Saúde e Desenvolvimento, 2009b. (Série A. Normas e manuais Técnicos).

Ministério da Saúde, Secretaria de Ciência, Tecnologia e Insumos Estratégicos, Departamento de Ciência e Tecnologia. - Brasília: Ministério da Saúde, 2010a. 48 p. - (Série B. Textos Básicos em Saúde). Disponível em: < http://bvsms.saude.gov.br/bvs/publicacoes/politica nacional gestao tecnologias sa ude.pdf>. Acesso em: 15 de jun. 2014.

. Ministério do Planejamento, Orçamento e Gestão. Instituto Brasileiro de Geografia e Estatística, 2010b. Contagem Populacional. Disponível em: <http://censo2010.ibge.gov.br/>. Acesso em: ago. 2013.

Portaria $N^{\circ}$ 2.488, de 21 de outubro de 2011. Disponível em: < http://bvsms.saude.gov.br/bvs/saudelegis/gm/2011/prt2488 $21 \quad 10$ 2011.html>

Acesso em: 26 jan. 2014.

. Ministério da Saúde. Política Nacional de Atenção Básica, 2012a.

. Ministério do Desenvolvimento, Indústria e Comércio Exterior. Secretaria

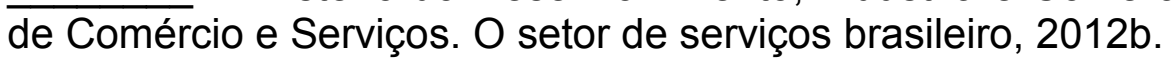

BRYMAN, A. Research methods and organization studies. London: Biddles, 1989. Contemporacy Social Research Series, v. 20.

BURNS, R. Introduction to research methods. London, UK: Sage, 2000.

CAMARGO Jr. K. R.; CAMPOS, E. M. S.; BUSTAMANTE-TEIXEIRA, M. T.; MASCARENHAS, M. T. M.; MAUAD, N.M.; FRANCO, T. B.; RIBEIRO, L. C.; ALVES, M. J. M. Avaliação da atenção básica pela ótica político-institucional e da organização da atenção com ênfase na integralidade. Cad Saúde Pública, 2008.

CAMPOS, G. W. S. Saúde Paidéia. $3^{a}$ ed. São Paulo: Editora Hucitec, 2007.

CAMURI, D.; DIMENSTEIN, M. Processos de Trabalho em Saúde: práticas de cuidado em saúde mental na estratégia saúde da família, Saúde Soc. São Paulo, v.19, n.4, p.803-813, 2010.

CASSELL, C.; BISHOP, V.; SYMON, G.; JOHNSON, P; BUEHRING, A. Learning to be a qualitative management researcher. Management Learning, vol. 40 (5), 2009.

CECÍLIO, L. C. O. As necessidades de saúde como conceito estruturante na luta pela integralidade e equidade na atenção à saúde. In: PINHEIRO, R.; MATTOS, R. A. de (Org.). Os sentidos da integralidade na atenção e no cuidado à saúde. Rio de Janeiro: ABRASCO, 2001.

COLAMEO, G.; QUAGGIO, F. M.; SILVA, M. T.; SILVEIRA, C. Análise da organização do trabalho no Programa de Saúde da Família. Inquérito com usuários e profissionais, percepção dos gestores e estudos sobre o trabalho no PSF. São Paulo: Centro de Estudos de Cultura Contemporânea; Consórcio Medicina USP, v. 3, pp. 129-171, 2007. 
CRESWELL, J. W. Research design: qualitative, quantitave, and mixed methods approaches; 3 ed. London, Sage Publications, 2009.

CREVELIM, M. A.; PEDUZZI, M. A participação da comunidade na equipe de saúde da família. Como estabelecer um projeto comum entre trabalhadores e usuários? Ciência \& Saúde Coletiva, 10(2), pp. 323-31, 2005.

DREJER, A. Organisational learning and competence development. The Learning Organization, v. 7, n. 4, pp. 206, 2000.

DUSSAULT, G. A gestão dos serviços públicos de saúde: características e exigências. Rev. Adm. púb., Rio de Janeiro, 26 (2):8-19, 1992.

EISENHARDT, K. M. Building theories from case study research. Academy of Management Review, vol. 14, n. 4, pp, 532-550, 1989.

FARIA, H. X.; ARAUJO, M. D. Uma perspectiva de análise sobre o processo de trabalho em saúde: produção do cuidado e produção de sujeitos. Saúde Soc. São Paulo, v.19, n.2, p.429-439, 2010.

FERRI S. M. N.; PEREIRA, M. J. B.; MISHIMA, S. M.; CACCIA-BAVA, M. do C. G.; ALMEIDA, M. C. P. As tecnologias leves como geradoras de satisfação em usuários de uma unidade de saúde da família. Interface - Comunic., Saúde, Educ., v.11, n.23, p.515-29, 2007.

FEUERWERKER, L. C. M. (Organizadora) Micropolítica e saúde: produção do cuidado, gestão e formação. Porto Alegre: Rede UNIDA, 2014. 174 p. (Coleção Micropolítica do Trabalho e o Cuidado em Saúde)

FRANCO, T. B.; MERHY, E. E. Programa de Saúde da Família (PSF): contradições de um programa destinado à mudança do modelo tecnoassistencial. In: MERHY, E.E. et al. (Org). $O$ trabalho em saúde: olhando e experienciando o SUS no cotidiano. $3^{a}$ Edição. São Paulo: Hucitec, 2006. p.53-124.

FRANCO, T. B.; BUENO, W. S.; MERHY, E. E. O Acolhimento e os processos de trabalho em saúde: o caso de Betim, Minas Gerais, Brasil. Cadernos de Saúde Pública. Rio de Janeiro, v. 15 (2), 1999, p. 345-353.

FITZSIMMONS, J. A; FITZSIMMONS, M. J. Administração de serviços: operações, estratégia e tecnologia da informação. Porto Alegre: Bookman, 2000.

FLEURY, M. T. L.; FLEURY, A. Estratégias empresariais e formação de competências: um quebra cabeça caleidoscópio da indústria brasileira. São Paulo, Atlas, 2000.

. Construindo o Conceito de Competência. RAC, Edição Especial, 2001.

Apresentação da edição brasileira. In: Objetivo Competência: Por uma nova lógica. São Paulo: Atlas, 2008.

GADREY, J. Emprego, produtividade e avaliação do desempenho dos serviços. In: SALERNO, M. S. (org) Relação de serviço: produção e avaliação. São Paulo: editora Senac São Paulo, 2001. (série trabalho e sociedade).

GANGA, G. M. D. Trabalho de conclusão de curso (TCC) na engenharia de produção: um guia prático de conteúdo e forma. São Paulo: Atlas, 2012.

GATTI, B. A. Grupo focal na pesquisa em ciências sociais e humanas. Brasília: Líber Livro Editora, 2005. 
GEPHART, R. P. Jr. Qualitative research and the academy of management journal. Academy of Management Journal, 2004, n. 4, pp. 454-462.

GIANESI, I. G. N.; CORREAA, H. L. Administração estratégica de serviços: operações para a satisfação do cliente. $1^{a}$ edição, $22^{a}$ reimpressão. São Paulo: Atlas, 2012.

GIGLIOTTI, C.; SANTOS, M. J. A expansão urbana de Caraguatatuba (1950-2010): Uma análise das transformações sócio-espaciais. Caminhos de Geografia, v. 14, n. 46, 2013.

GIL, A. C. Como elaborar projetos de pesquisa. São Paulo: Atlas, 1996.

GIMENES, F. R. E. A segurança de pacientes na administração de medicamentos em uma unidade de terapia intensiva de um hospital geral do interior paulista: a abordagem restaurativa em saúde. 2011. 231p. Tese (Doutorado em Enfermagem) Escola de Enfermagem de Ribeirão Preto, Universidade de São Paulo, Ribeirão Preto, 2011.

GONÇALVES, R. B. M. Práticas de saúde processos de trabalho e necessidades. São Paulo: Cadernos Cefor, 1992.

GRANT, R. M. The resource-based theory of competitive advantage: Implications for strategy formulation. California Management Review, v.33, n.3, p.114-135, 1991.

GRONROOS, C. Marketing: gerenciamento e serviços. Rio de Janeiro: Campus, 1995.

HIRATA, H. Prefácio à edição brasileira de Objetivo Competência. In: ZARIFIAN, P. Objetivo Competência: Por uma nova lógica. São Paulo: Atlas, 2008.

HUBAULT, F. Os desafios relacionados à mobilização da subjetividade na relação de serviço. In: SALERNO, M. S. (org) Relação de serviço: produção e avaliação. São Paulo: editora Senac São Paulo, 2001. (Série trabalho e sociedade).

IBGE. Instituto Brasileiro de Geografia e Estatística. Sinopse do Senso Demográfico $2010 . \quad$ Disponível em: <http://www.censo2010.ibge.gov.br/sinopse/index.php?dados=29\&uf=35>. Acesso em: 14 de out. 2014.

INSTITUTO POLIS. Diagnóstico urbano socioambiental e Programa de Desenvolvimento Sustentável em municípios da Baixada Santista e Litoral Norte do estado de São Paulo. Boletim nº 1 Caraguatatuba. Julho/Agosto, 2012.

JOHNSTON, R.; CLARK, G. Administração de operações de serviço. São Paulo: Editora Atlas, 2011.

KAWATA L. S.; MISHIMA, S. M.; CHIRELLI, M. Q.; PEREIRA, M. J. B.; MATUMOTO, S.; Fortuna, C. M. Atributos mobilizados pela enfermeira na Saúde da Família: aproximação aos desempenhos na construção da competência gerencial. Rev Esc Enferm USP, 45(2), pp. 349-55, 2011.

KOTLER, P.; KELLER, K. L. Administração de marketing. $12^{a}$ edição. São Paulo: Pearson, 2006.

LEVORLINO, S. A.; PELICIONI, M. C. F. A utilização do grupo focal como metodologia qualitativa na promoção da saúde. Rev Esc Enf USP, v. 35, n.2, p.115-21, 2001. 
LOVELOCK, C. Product plus: produto + serviço = vantagem competitiva. São Paulo, Makron Books, 1995.

MARCK, P. B. Discourse: field notes from research and restoration in the backcountry of modern health care, Can J Nurs Res, v. 38, n. 2, 11-23, 2006.

MARQUI, A. B. T. de et al. Caracterização das equipes da Saúde da Família e de seu processo de trabalho. Rev. esc. enferm. USP [online]. 2010, vol.44, n.4, pp. 956-961. ISSN 0080-6234. http://dx.doi.org/10.1590/S0080-62342010000400014.

MARSHALL, C.; ROSSMAN, G. B. Designing qualitative Research. 2 ed. Thousand Oaks, CA: Sage, 1995.

MARTINS, R. A. Abordagens quantitativa e qualitativa. In: Miguel, P. A. C. (coordenador). Metodologia de pesquisa em engenharia de produção e gestão de operações. Rio de Janeiro: Elsevier, 2010, pp. 45-61.

MARX, K. Processo de Trabalho e Processo de Produção de Mais-Valia. In: O Capital. Editora Nova Cultural Ltda, 1996 ( $1^{\mathrm{a}}$ ed. 1867).

MASCIA, F. L. O trabalho da supervisão: o ponto de vista da ergonomia. In: Falzon, P. Ergonomia. São Paulo: Edgard Blucher, 2007.

MASCIA, F. L.; DESTEFANO, R. L.; MESQUITA, R.; VEZZÁ, F. M. G.; WATANABE, M.; ZUCCOLOTTO, S. O trabalho no PSF sob a ótica da ergonomia. In: VIANA, A. L. A. (Coord.). Inquérito com usuários e profissionais, percepção dos gestores e estudos sobre o trabalho no PSF. São Paulo: Centro de Estudos de Cultura Contemporânea; Consórcio Medicina USP, v. 3, pp. 173-205, 2007.

MATTOS, R. A. A integralidade na prática (ou sobre a prática da integralidade). Cad. Saúde Pública [online]. 2004, vol.20, n.5, pp. 1411-1416.

MATUMOTO, S. O acolhimento: um estudo sobre seus componentes e sua produção em uma unidade da rede básica de serviços de saúde. 1998. 219 f. Dissertação (Mestrado em Enfermagem de Saúde Pública) - Escola de Enfermagem de Ribeirão Preto, Universidade de São Paulo, Ribeirão Preto, 1998.

MERHY, E. E. Um ensaio sobre o médico e suas valises tecnológicas: contribuições para compreender as reestruturações produtivas do setor Saúde. São Paulo: Interface - Comunic, Saúde, Educ., 2000.

Saúde: a cartografia do trabalho vivo. São Paulo: Hucitec, 2007.

MERHY, E. E.; FRANCO, T. B. Por uma Composição Técnica do Trabalho Centrada nas Tecnologias Leves e no Campo Relacional. Saúde em Debate, ano XXVII, v.27, N. 65, Rio de Janeiro, 2003.

MERHY; FRANCO. 2001. Programa de Saúde da Família: somos contra ou a favor? Só analisando antes, para dizer depois. Disponível em: < http://www.eeaac.uff.br/professores/merhy/indexados-09.pdf>. Acesso em: 23 ago. 2013.

MERHY, E. E.; FEUERWERKER, L.C.M. Novo olhar sobre as tecnologias de saúde: uma necessidade contemporânea. In: MANDARINO, A. C. S. \& GOMBERG, E. (org) Leituras de novas tecnologias e saúde. Bahia: Editora UFS, 2009, pp. 29-56. ISBN 978-85- 7822-075-4. 
MIGUEL, P. A. C. Estudo de caso na engenharia de produção: estruturação e recomendações para sua condução. Produção, v. 17, n. 1, p. 216-229, jan./abr. 2007.

Adoção do estudo de caso na Engenharia de Produção. In: MIGUEL, P. A. C. (coordenador). Metodologia de pesquisa em engenharia de produção e gestão de operações. Rio de Janeiro: Elsevier, 2010, pp. 129-143.

MILLS, J.; PLATTS, K.; BOURNE, M. Applying resource-based theory: methods, outcomes and utility for managers. International Journal of Operations \& Production Management, v. 23, n.2, 2003.

MINAYO, M. C. de S. O desafio do conhecimento: pesquisa qualitativa em saúde. 6ª Edição. São Paulo: Hucitec, 1999.

MORGAN, D. L. Focus group as qualitative research. London: Sage, 1997.

MOTA, S. Urbanização e meio ambiente. Rio de Janeiro: Abes, 1999.

NEUMAN, W. L. Social research methods: qualitative and quantitative approaches. 2 ed. Upper Saddle River, NJ: Prentice Hall, 2007.

NITA, M. E.; SECOLI, R. S.; NOBRE, M. R. C. e.; ONO-NITA, S. K.; CAMPINO, A. C. C.; SANTI, F. M.; COSTA, A. M. N.; CARRILHO, F. J., Avaliação de tecnologias em saúde: Evidência Clínica, Análise Econômica e Análise de decisão. Porto Alegre: Artmed, 2010.

NORMANN, R. Administração de serviços: estratégias e liderança na empresa de serviços. São Paulo: Atlas, 1993.

PEDUZZI, M. Equipe multiprofissional de saúde: a interface entre trabalho e interação. 1998. Tese de doutorado - Faculdade de Ciências Médicas, Universidade Estadual de Campinas, Campinas, 1998.

PENROSE, E. T. The Growth of the Firm - A Case Study: The Hercules Powder Company. The Business History Review, Vol. 34, No. 1, 1959.

PREFEITURA MUNCIPAL DA ESTÂNCIA BALNEÁRIA DE CARAGUATATUBA. Plano de Gestão Municipal de Gestão Integrada de Resíduos Sólidos do Município de Caraguatatuba, 2013. Disponível em: < http://www.caraguatatuba.sp.gov.br/pmc/uploads/services/Meio Ambiente/Plano Re siduos Solidos.pdf> Acesso em: 12 de out. 2014.

RIBEIRO, E. M.; PIRES, D.; BLANK, V. L. G. A teorização sobre processo de trabalho em saúde como instrumental para análise do trabalho no Programa Saúde da Família. Cad. Saúde Pública [online]. 2004, vol.20, n.2 [cited 2015-02-20], pp. 438446 . Available from: <http://www.scielo.br/scielo.php?script=sci arttext\&pid=S0102311X2004000200011\&lng=en\&nrm=iso>. 311X. http://dx.doi.org/10.1590/S0102-311X2004000200011.

ROBBINS S. P. Comportamento organizacional. $9^{a}$ ed. São Paulo: Prentice Hall, 2002.

ROSA, R. B.; PELEGRINI, A. H. W.; LIMA, M. A. D. da S. Resolutividade da assistência e satisfação de usuários da Estratégia Saúde da Família. Rev. Gaúcha Enferm. (Online), Porto Alegre, v. 32, n. 2, p. 345-351, 2011.

RUMELT, R. P. Towards a strategic theory of the firm. Competitive Strategic Management. Prentice-Hall, Englewood Cliffs, NJ, pp. 556-570, 1984. 
SALERNO, M. S. A seu serviço: interrogações sobre o conceito, os modelos de produção e o trabalho em atividades de serviço. In:

serviço: produção e avaliação. São Paulo: Senac, 2001. (Org.). Relação de

SANTOS, A. M.; ASSIS, M. M. A.; NASCIMENTO, M. A. A.; JORGE, M. S. B. Vínculo e autonomia na prática de saúde bucal no Programa Saúde da Família. Rev Saúde Pública, 42(3), p. 464-470, 2008.

SEIXAS, S. R. C.; BARBOSA, R. V.; RENK, M.; ASMUS, G. F.; MELLO, A. Y. I. Mudanças ambientais globais e saúde: uma abordagem preliminar sobre o município de Caraguatatuba, Litoral Norte Paulista. Teoria \& Pesquisa, v. 19, 2010. p. 29-59.

SILVA, I. Z. Q. J.; TRAD, L. A. B. Team work in the PSF: investigating the technical articulation and interaction among professionals, Interface - Comunic., Saúde, Educ., v.9, n.16, p.25-38, 2005.

SILVA, M. G.; FERNANDES, J. D.; REBOUÇAS, L. C.; RODRIGUES, G. R. S.; TEIXEIRA, G. A.; SILVA, R. S. de O. Publicações que utilizaram o grupo focal como técnica de pesquisa: o que elas nos ensinam? Ciência, cuidado e saúde, vol. $12, \mathrm{n}^{\circ} 2$, 2013.

SILVA, M. T. A organização do trabalho para a produção de acordo com a lógica de serviço: os mecanismos de coordenação em atividades de atendimento ao cliente. Tese (livre docência) - Departamento de Engenharia de Produção, Escola Politécnica, Universidade de São Paulo, Brasil, 2010.

SILVA, M. T.; LANCMAN, S.; ALONSO, C. M. do C. Consequências da intangibilidade na gestão dos novos serviços de saúde mental. Rev Saúde Pública, 43(Supl. 1), pp. 36-42, 2009.

SPINK, M. J. P. A psicologia em diálogo com o SUS: prática profissional e produção acadêmica. São Paulo: Casa do Psicólogo, 2007.

STANCATO, K.; ZILLI, P. T. Fatores geradores da rotatividade dos profissionais de Saúde: uma revisão de literatura. Rev. adm. saúde; vol. 12, 2010.

STARFIELD, B. Atenção Primária: equilíbrio entre necessidades de saúde, serviços e tecnologia. Brasília: UNESCO, Ministério da Saúde, 2002.

TEBOUL, J. Gerenciando a dinâmica da qualidade. São Paulo: Editora Qualitymark, 1991.

TURRINI, R. N. T.; LEBRAO, M. L.; CESAR, C. L. G. Resolutividade dos serviços de saúde por inquérito domiciliar: percepção do usuário. Cad. Saúde Pública. Rio de Janeiro, v. 24, n. 3, p. 663-674, 2008.

VALENTIM, I. V. L.; KRUEL, A. J. A importância da confiança interpessoal para a consolidação do Programa de Saúde da Família. Ciência \& Saúde Coletiva, 12(3), pp. 777-788, 2007.

VALENTIN, E. K. SWOT analysis from a resource-based view. Journal of Marketing Theory and Practice; v. 9, n. 2, p. 54-69, Spring, 2001.

VANDERMERWE, S.; RADA, J. Servitization of business: Adding value by adding services. European Management Journal, v. 6, n. 4, p. 314-324, 1988. 
VIEGAS, S. M. da F.; PENNA, C. M, de M. Construção da integralidade no trabalho cotidiano da equipe saúde da família. Esc Anna Nery, jan -mar; 17 (1), pp.133 - 141, 2013

VOSS, C.; TSIKRIKTSIS, N.; FROHLICH, M.; Case research in operations management. International Journal of Operations \& Production Management, vol. 22, n. 2, pp, 195-219, 2002.

WERNERFELT, B, A Resource-Based View of the Firm. Strategic Management Journal, v.5 p.171-180, 1984.

YIN, R. K. Estudo de caso: planejamento e métodos. 4 ed. Porto Alegre: Bookman, 2010.

ZARIFIAN, P. Organização qualificante e modelos da competência: que razões? Que aprendizagens? Revista europeia de formação profissional, n. 5, CEDEFOP, 1995.

. Mutação dos Sistemas Produtivos e Competências Profissionais: a produção industrial do serviço. In: SALERNO, M. S. (Org.) Relação de Serviço: produção e avaliação. São Paulo: Senac, 2001a.

. Valor, organização e competência na produção de serviço: esboço de um modelo de produção de serviço. In: SALERNO, M. S. (Org.) Relação de Serviço: produção e avaliação. São Paulo: Senac, 2001b.

Comunicação e Subjetividade nas Organizações. In: DAVEL, E.; VERGARA, S. C. (orgs.). Gestão com Pessoas e Subjetividade. $1^{a}$ Edição. São Paulo: Atlas, 2001c.

O Modelo da Competência: trajetória histórica, desafios atuais e propostas. São Paulo: Ed. Senac São Paulo, 2003.

Objetivo Competência: Por uma nova lógica. São Paulo: Atlas, 2008. 
ANEXOS 


\section{ANEXO 1 - Roteiro Primeiro Encontro}

1) Discutam quais são as dificuldades/entraves presentes no processo de trabalho de vocês?

2) Quais os pontos positivos presentes no processo de trabalho de vocês?

3) O que é necessário para o trabalho de vocês surtir o efeito desejado??

4) Compare o que está dito (nos documentos do Ministério da Saúde) sobre o que o PSF deve realizar e o que é, efetivamente, realizado no trabalho de vocês?

5) Qual o resultado do seu trabalho? Qual a maior contribuição de sua equipe? 


\section{ANEXO 2 - Roteiro Segundo Encontro}

1) O que vem à mente de vocês quando falamos em recursos?

2) Quanto que uma boa relação com o usuário é importante para o resultado de seu serviço?

3) Vocês acham que os usuários do serviço realmente utilizam as informações/orientações fornecidas pela ESF?

4) No encontro anterior, identifiquei na fala de vocês os seguintes recursos... Baseados nesta lista, gostaria de fazer duas questões:

a. Há algum comentário que queiram fazer sobre essa lista (algum estranhamento)?

b. Há algo que vocês retirariam ou acrescentariam a ela?

5) Gostaria que vocês falassem mais diretamente sobre os seguintes recursos (relacionais): acolhimento, vínculo e confiança. Tentem englobar os seguintes pontos: O que é? Como é realizado/desenvolvido? Quais as dificuldades encontradas? O que favorece ou prejudica o seu desenvolvimento?

6) Quando falamos em recurso, uma questão importante é o controle de seu uso. Para recursos imateriais, o controle está muito relacionado a questão do grau do seu desenvolvimento. Assim, como podemos medir o grau de desenvolvimento desses recursos? Há algum instrumento de avaliação relacionado a esses recursos? 


\section{ANEXO 3 - Categorizações Parciais de Recursos - Unidade 1}

\section{Grupo ACS e AUX}

\begin{tabular}{|c|c|c|}
\hline & Tipos de recursos & Recursos identificados \\
\hline \multirow{2}{*}{ Tangíveis } & $\begin{array}{l}\text { 1. Equipamentos e } \\
\text { materiais }\end{array}$ & Aparelho de aferir pressão, caneta, lápis, papel \\
\hline & $\begin{array}{l}\text { 2. Sistema e recursos } \\
\text { processuais }\end{array}$ & \\
\hline \multirow{5}{*}{ Intangíveis } & 3. Humano & $\begin{array}{l}\text { Doar-se ao trabalho, escuta, persistência, } \\
\text { profissionais, trabalhar em equipe }\end{array}$ \\
\hline & 4. Organizacional & \\
\hline & 5. Reputacional & \\
\hline & 6. Relações & Comunicação, motivação, união, vínculo \\
\hline & 7. Informacional & \\
\hline
\end{tabular}

\section{Grupo ENF e MED}

\begin{tabular}{|c|c|c|}
\hline & Tipos de recursos & Recursos identificados \\
\hline \multirow{2}{*}{ Tangíveis } & 1. Equipamentos e ateriais & Estrutura física \\
\hline & $\begin{array}{l}\text { 2. Sistema e recursos } \\
\text { processuais }\end{array}$ & \\
\hline \multirow{5}{*}{ Intangíveis } & 3. Humano & $\begin{array}{l}\text { Agilidade, capacidade de aprender, capacidade } \\
\text { de resolver problemas, doar-se ao trabalho, } \\
\text { profissionais, trabalhar em equipe, visão }\end{array}$ \\
\hline & 4. Organizacional & $\begin{array}{l}\text { Autonomia, flexibilidade, organização, } \\
\text { solidariedade entre instâncias }\end{array}$ \\
\hline & 5. Reputacional & \\
\hline & 6. Relações & $\begin{array}{l}\text { Comprometimento, } \\
\text { responsabilidade, união, vínculo }\end{array}$ \\
\hline & 7. Informacional & Sistema informação \\
\hline
\end{tabular}




\section{ANEXO 4 - Categorizações Parciais de Recursos - Unidade 2}

\section{Grupo ACS e AUX}

\begin{tabular}{|c|c|c|}
\hline & Tipos de recursos & Recursos identificados \\
\hline \multirow{2}{*}{ Tangíveis } & 1. Equipamentos e materiais & $\begin{array}{l}\text { Borracha, caneta, mochila, papel, prancheta, } \\
\text { protetor solar }\end{array}$ \\
\hline & $\begin{array}{l}\text { 2. Sistema e recursos } \\
\text { processuais }\end{array}$ & \\
\hline \multirow{5}{*}{ Intangíveis } & 3. Humano & $\begin{array}{l}\text { Capacidade de aprender, capacidade de } \\
\text { resolver problemas, competência, } \\
\text { conhecimento técnico, doar-se ao trabalho, } \\
\text { escuta, ética, olhar humanizado, profissionais, } \\
\text { trabalhar em equipe }\end{array}$ \\
\hline & 4. Organizacional & Autonomia, organização \\
\hline & 5. Reputacional & Confiança (serviço) \\
\hline & 6. Relações & $\begin{array}{l}\text { Acolhimento, atenção, compreensão, } \\
\text { comprometimento, comunicação, experiência, } \\
\text { humildade, interesse, motivação, respeito, } \\
\text { vínculo }\end{array}$ \\
\hline & 7. Informacional & Sistema informatizado de informação \\
\hline
\end{tabular}

\section{Grupo ENF e MED}

\begin{tabular}{|c|c|c|}
\hline & Tipos de recursos & Recursos identificados \\
\hline \multirow[t]{2}{*}{ Tangíveis } & 1. Equipamentos, materiais & $\begin{array}{l}\text { Água destilada, autoscópio, cartão de pré- } \\
\text { natal, estetoscópio, frasco para coletar } \\
\text { preventivo, luva, medicamentos, sonar, soro } \\
\text { glicosado }\end{array}$ \\
\hline & $\begin{array}{l}\text { 2. Sistema e recursos } \\
\text { processuais }\end{array}$ & \\
\hline \multirow{5}{*}{ Intangíveis } & 3. Humano & Profissionais, trabalhar em equipe \\
\hline & 4. Organizacional & Organização, segurança \\
\hline & 5. Reputacional & \\
\hline & 6. Relações & $\begin{array}{l}\text { Comunicação, engajamento, experiência } \\
\text { motivação, reconhecimento, respeito, vínculo }\end{array}$ \\
\hline & 7. Informacional & \\
\hline
\end{tabular}




\section{ANEXO 5 - Quadro com os Temas Finais}

\begin{tabular}{|c|c|}
\hline Tema & Categoria Reduzida \\
\hline \multirow{5}{*}{$\begin{array}{l}\text { 1) Concebendo recursos e } \\
\text { debatendo a ausência de } \\
\text { recursos materiais e não } \\
\text { materiais }\end{array}$} & Sobre funcionários: a carência \\
\hline & Sobre funcionários: as consequências de sua carência \\
\hline & Sobre recursos: a carência \\
\hline & Sobre recursos: consequências de sua oferta e carência \\
\hline & Concepção e considerações sobre recursos materiais e não materiais \\
\hline \multirow{4}{*}{$\begin{array}{l}\text { 2) Debatendo a importância } \\
\text { das relações e os principais } \\
\text { recursos das relações }\end{array}$} & $\begin{array}{l}\text { Considerações sobre o vínculo: definições, dificuldades, possibilidades } \\
\text { para seu desenvolvimento e importância para o serviço }\end{array}$ \\
\hline & $\begin{array}{l}\text { Considerações sobre o acolhimento: definições, dificuldades, } \\
\text { possibilidades para seu desenvolvimento e importância para o serviço }\end{array}$ \\
\hline & $\begin{array}{l}\text { Considerações sobre confiança: dificuldades, possibilidades para seu } \\
\text { desenvolvimento e importância para o serviço }\end{array}$ \\
\hline & $\begin{array}{l}\text { Sobre o relacionamento entre trabalhadores e entre trabalhadores e } \\
\text { usuários }\end{array}$ \\
\hline \multirow{4}{*}{$\begin{array}{l}\text { 3) A repercussão de } \\
\text { questões organizacionais e } \\
\text { de gestão sobre a produção } \\
\text { do cuidado }\end{array}$} & Refletindo sobre as metas \\
\hline & Sobre a rotatividade de profissionais \\
\hline & Sobre a organização do trabalho em equipe \\
\hline & $\begin{array}{l}\text { Relações entre organizações, entre profissões e questões resultantes } \\
\text { da coexistência de diversos vínculos de trabalho }\end{array}$ \\
\hline \multirow{3}{*}{$\begin{array}{l}\text { 4) Concebendo o modelo e } \\
\text { o foco de atuação }\end{array}$} & Considerações sobre os trabalhos de orientação e prevenção \\
\hline & Sobre a avaliação do modelo, do serviço e dos trabalhadores \\
\hline & Concepção do modelo e suas decorrências \\
\hline \multirow{3}{*}{$\begin{array}{l}\text { 5) Conhecimentos, } \\
\text { habilidades e atitudes } \\
\text { importantes para os } \\
\text { trabalhadores da saúde }\end{array}$} & Sobre o perfil necessário para o trabalhador ser competente \\
\hline & Considerações a respeito das carências dos trabalhadores \\
\hline & Sobre fontes de estímulo e desmotivação \\
\hline
\end{tabular}




\begin{tabular}{l||l}
\hline $\begin{array}{l}\text { 6) Percebendo debilidades } \\
\text { e fontes de frustrações }\end{array}$ & Debilidades operacionais do modelo \\
\hline \hline $\begin{array}{l}\text { 7) Vislumbrando as } \\
\text { possibilidades } \\
\text { melhorias }\end{array}$ & Pe \\
\hline \hline
\end{tabular}




\section{ANEXO 6 - Termo de Consentimento}

Projeto de Pesquisa: A organização do trabalho para o desenvolvimento de recursos imateriais em equipes de saúde da família: um estudo de caso no município de Caraguatatuba.

Essas informações estão sendo fornecidas para sua participação voluntária neste estudo, que será realizado através de entrevistas individuais e aplicação de questionário. A pesquisa tem como objetivo identificar os recursos considerados essenciais para a produção do serviço educação em saúde, no contexto da Estratégia de Saúde da Família (ESF) e, sobretudo, examinar como deve ser efetivada sua gestão. .

- Não há benefício direto ao entrevistado, pois consiste em uma pesquisa sem fins lucrativos, que será utilizada na formação (mestrado) do pesquisador Edivaldo Alberto Bolsam Alves.

- O entrevistado está suficientemente esclarecido dos possíveis riscos e desconfortos e poderão, a qualquer momento, solicitar outros esclarecimentos a esse respeito.

- Em qualquer etapa do estudo o entrevistado terá acesso ao profissional responsável pela pesquisa para esclarecimento de eventuais dúvidas. $O$ principal pesquisador, Edivaldo Alberto Bolsam Alves, do Departamento de Pósgraduação em Engenharia de Produção da Escola Politécnica da Universidade de São Paulo, pode ser contatado através do telefone (11) 3091-5363 Ramal 452 ou do e-mail betobolsam@usp.br.

- É garantida a liberdade do entrevistado de retirar seu consentimento a qualquer momento e deixar de participar do estudo, sem qualquer prejuízo.

- As entrevistas poderão ser gravadas (arquivos em áudio, formato digital 3gpp ou similar). Os registros ficarão em posse do principal pesquisador por tempo indeterminado. As transcrições, assim como os arquivos em áudio, poderão ser disponibilizados ao entrevistado, caso o mesmo os requeira.

- Ao fim do estudo, será solicitado ao entrevistado que assine o termo de cessão de direitos sobre seu depoimento oral, o que permitirá a publicação do depoimento no todo ou em parte.

- Não há despesas pessoais para o entrevistado e não há compensação financeira pela sua participação.

- Os dados e o material coletado serão usados somente para fins de pesquisa e publicação acadêmica, no Brasil ou no exterior, garantido o anonimato do participante.

\section{Declaração de consentimento}

Acredito ter sido suficientemente informado e esclarecido a respeito das informações que li, descrevendo o estudo "A organização do trabalho para o desenvolvimento de recursos imateriais em equipes de saúde da família: um estudo de caso no município de Caraguatatuba". Discuti com o pesquisador Edivaldo Alberto Bolsam Alves sobre a minha decisão em participar desse estudo. Ficaram claros para mim 
quais são os propósitos do estudo, os procedimentos a serem realizados, seus desconfortos e riscos e as garantias de esclarecimentos permanentes. Ficou claro também que minha participação não envolve despesas e que poderei retirar o meu consentimento a qualquer momento, durante o mesmo, sem penalidades. Concordo voluntariamente em participar desse estudo, através da assinatura do presente termo, em duas vias, ficando uma em meu poder e outra em poder do responsável pela pesquisa.

Nome do entrevistado

RG:

Declaro que obtive de forma apropriada e voluntária o consentimento livre e esclarecido do $\mathrm{Sr}(\mathrm{a})$

Edivaldo Alberto Bolsam Alves

RG: 28.658.726-9

Caraguatatuba, de de 